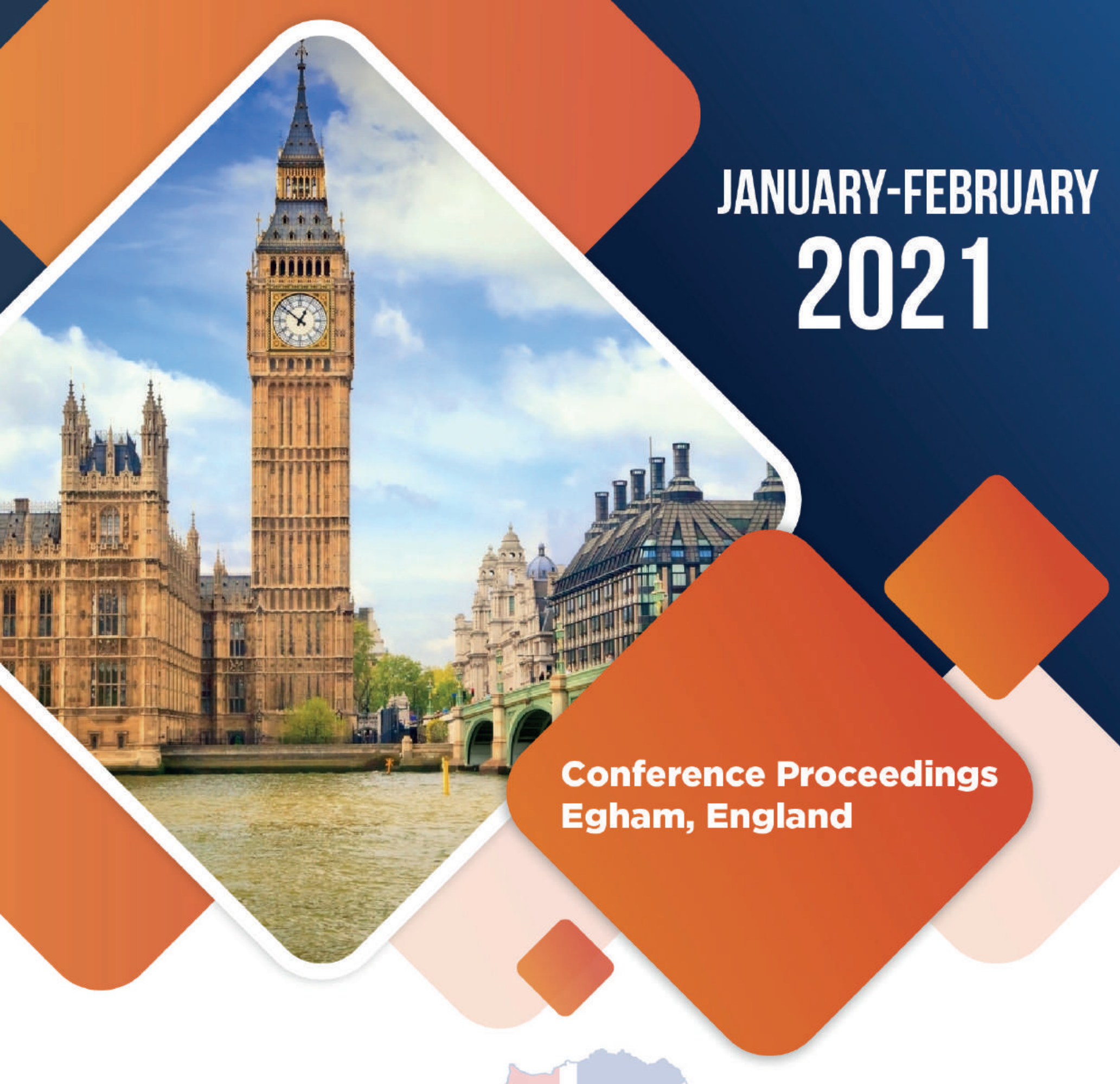

International scientific and practical Conference
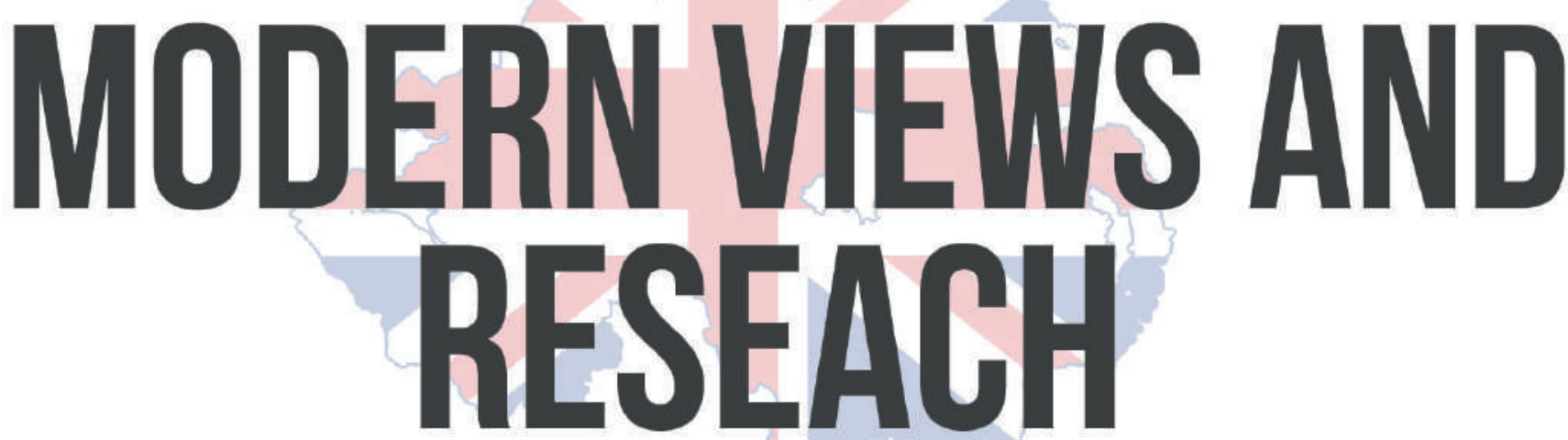


\title{
Modern views and research - 2021
}

Chief editor: R.Shilton

\author{
Independent Publishing Network Ltd \\ Mailing address - MB \#1869, PO BOX 229, EGHAM, TW20 \\ $8 \mathrm{WZ}, \mathrm{UK}$ \\ Registered Office - 71-75 Shelton Street, Covent Garden, \\ London, WC2H 9JQ, UK \\ Company Number 11541223 \\ International scientific and practical Conference \\ Modern views and research - 2021, January-February, 2021: Egham. \\ Independent Publishing Network Ltd -14 p.
}

\section{Date signed for printing,}

For students, research workers

ISBN 978-1-83853-487-5

DOI: http://doi.org/10.37057/E_7

Publisher: Independent Publishing Network.

(C) Authors, 2021

(C) Independent Publishing Network Ltd

Modern views and research - 2021

The collection of scientific papers available on

Virtualconferences.press 


\section{MEDICAL SCIENCE}

Vokhidova D.A., Usmanova D.D., Vokhidov A.M.,

CEREBRAL PERFUSION STATUS IN DIFFERENT SUBTYPES OF ISCHEMIC

STROKE

Khikmatullaeva A.S., Ibadullaeva N.S., Nazarova F.N.

FREQUENCY OF ANTIBODIES TO SARS-COV-2 IN RECONVALESCENTS COVID-19 ........7

Agzamova Shoira, Tashpulatova Fatima, Akhmedova Firuza

PECULIARITIES IN THE PHYSICAL DEVELOPMENT OF CHILDREN WITH FETAL

INFECTION WITH CYTOMEGALOVIRUS, HERPES SIMPLEX 1 AND 2 TYPES,

CHLAMYDIA TRACHOMATIS AND ASSOCIATED INFECTION

Allanazarova Mohira

QUANTITATIVE ANALYSIS OF "SILYBUM MARIANUM” LIQUID EXTRACT.....

Azizova F.F., Sabirov J.M., Atakhanova L.E.

ESTIMATION OF PARAMETERS OF REMODELING OF THE RIGHT HEART

REGIONS AND THE LEVEL OF PULMONARY HYPERTENSION IN PATIENTS WITH

INTRA-ABDOMINAL HYPERTENSION.

Bayjanov A.K., Khikmatullaeva A.S., Samatova I.R.

CLINICAL FEATURES OF COVID-19 DEPENDING ON THE SEVERITY OF THE

DISEASE

\section{PHILOLOGICAL SCIENCE}

Axmedova Sanobar Adilbekovna, Sabirova Sadoqat Davlatmuratovna,

Atajanova Iroda Ortiqovna

ESSENTIAL CUES FOR WRITING A SUCCESSFUL ESSAY.....

Khurshida Khodjayeva

SOME FEATURES OF THE TRAINING OF CONFERENCE INTERPRETERS IN THE

EUROPEAN UNION .... .18

\section{STATE AND LAW}

Ibrokhimova Zulxumor Solih qizi

ISSUES OF THE CONCEPT AND CLASSIFICATION OF CRIMES AGAINST THE

FAMILY IN THE CRIMINAL CODE OF THE REPUBLIC OF UZBEKISTAN.

Kuyliev Bobur Tulkinovich

THEORETICAL AND METHODOLOGICAL BASIS OF STUDYING THE CONTENT OF

POLITICAL CONSCIOUSNESS

G'ofurova Mavluda Botirjon qizi

LINGUOCULTURAL ASPECTS OF THE STUDY OF WORD MEANING

Izrailbekova Kamila Shavkatovna

STUDY OF THE FREQUENCY OF DEVELOPMENT OF SYNCHRONOUS AND

METACHRONOUS TUMORS IN PATIENTS WITH MALIGNANT NEOPLASMS OF THE

FEMALE REPRODUCTIVE SYSTEM

Jalolova Pokiza Muzaffarovna

APPLICATION OF ACT IN THE TEACHING OF ATOMIC PHYSICS

\section{CULTUROLOGY SCIENCE}

Aytmuratov J. Aytmuratova Z.

THE ROLE OF JIRAW IN KARAKALPAK NATIONAL MUSICAL ART. 35

\section{ECONOMIC SCIENCES}

Abduraimov Dilshod Muratkulovich

IMPROVING THE MECHANISM OF INNOVATIVE DEVELOPMENT OF REGIONAL

TOURISM INFRASTRUCTURE ON THE BASIS OF DIGITAL TECHNOLOGIES 
Khudoyberdiev Yusufjon Ollomurod oglu

THE ESSENCE OF THE FINANCIAL SYSTEM AND INFRASTRUCTURE

Tursunova Munisa Khujayor qizi, Tursunova Ibodat Khujayor qizi

TRENDS IN THE DEVELOPMENT OF INTERNET TECHNOLOGIES IN THE ERA OF

DIGITALIZATION OF THE ECONOMY..... .44

\section{HISTORICAL SCIENCES}

Tukhtabaev Azamjon Sharipkhujaevich

THE HISTORY OF HELICOPTER TRANSPORT IN UZBEKISTAN .46

\section{CHEMICAL SCIENCES}

S.Arslanov, E. Egamberdiev, G.Akmalova PHYSIOLOGICALLY ACTIVE POLYMERS WITH ANTITUBERCULOSIS ACTIVITY. 48

\section{PEDAGOGICAL SCIENCES}

Abdusamatova Shaxodat Hojiakbar qizi, Yuldasheva Maftuna Zokir qizi

METHODOLOGY OF TEACHING ON "APPLICATION OF CLOUDTY TECHNOLOGIES IN

EDUCATION" WITH ABCD METHOD.

Gulrukh M. Mirkhodjaeva

THE NATIONAL QUALIFICATIONS FRAMEWORKS AND ITS DEVELOPMENT IN UZBEKISTAN.

Islamova Dourdonakhon Rustamkhon kizi

DEVELOPMENT OF TOURISM POTENTIAL IN THE REPUBLIC OF UZBEKISTAN. TO

EXAMINE THE EDUCATIONAL IMPACT CIRCLES OF TOURISM.

Z.K. Yusupova

THE DEVELOPMENT OF THINKING AS A CONDITION FOR PERSONAL SELF-

GOVERNMENT IN THE CONTEXT OF DISTANCE LEARNING

\section{AGRICULTURAL SCIENCES}

Kozhevnikova A.G.

HARMFUL CICADAS DAMAGING COTTON

Usmanov S., Begjanov M., Nurjanov A.

DISTRIBUTION OF LOCUSTS IN THE COTTON FIELDS OF THE FERGANA VALLEY .....61

\section{TECHNICAL SCIENCE}

E. Egamberdiev, Yo.Ergashev, G.Rakhmanberdiev

OBTAINING A FILTER MATERIAL BASED ON BASALT FIBER USED FOR THE OIL

INDUSTRY.....

R. Saifutdinov, K. D. Mirsaidova

RESEARCH POSSIBILITY OF REPEAT THE USE OF WASHED WATER IN THE

PRODUCTION OF COTTON CELLULOSE.

Sobirov Ilxom Khaxramanovich, Usmanov Xayrulla Saydullaevich,

Khaitbaev Khursand Khushnudovich

CALCULATION OF IMPACT EFFECTS ON COTTON FLY UNDER EXISTING HORIZONTAL

CLEANING TECHNOLOGY

Sobirov Ilxom Khaxramanovich, Usmanov Xayrulla Saydullaevich, Khaitbaev Khursand CALCULATION OF FORCE EFFECTS ON COTTON FLY DURING CLEANING ON VERTICAL CLEANER 


\title{
MEDICAL SCIENCE
}

\section{CEREBRAL PERFUSION STATUS IN DIFFERENT SUBTYPES OF ISCHEMIC STROKE}

\author{
${ }^{1}$ Vokhidova D.A., ${ }^{1}$ Usmanova D.D., ${ }^{2}$ Vokhidov A.M., \\ 1. Department of Neurology, Pediatric Neurology and Medical Genetics \\ 2. TashPMI, Tashkent, Department of Informatics, Samarkand State \\ Medical Institute, Samarkand.mcshod89@gmail.com
}

Relevance. Acute cerebrovascular accidents are the second leading cause of death and the third leading cause of disability in the world. Currently, stroke is a global epidemic that threatens the life and health of the population around the world. About 17 million people suffer from strokes every year, $70 \%$ of whom live in low- or middle-income countries. Stroke deaths are projected to reach 7.8 million by 2030 unless there is a unified global response to stroke.

From half to two thirds of all ischemic strokes (IS) are to some extent associated with atherosclerotic lesions of extracranial arteries. Atherosclerotic plaques affect the precerebral (carotid, vertebral), large and middle cerebral arteries, mainly at the sites of their division, tortuosity and fusion. To detect atherosclerotic plaques and assess their condition (atherogenicity, embolism) among non-invasive methods, the method of ultrasound duplex scanning is the most widely used method... This method allows you to determine the violation of hemodynamics due to the presence of a plaque. The revealed changes in hemodynamics make it possible to objectively judge the degree of ischemic disorders in the brain.

The aim of the study is to assess the state of the main arteries of the head according to the data of ultrasound duplex scanning in the acute period of ischemic stroke, taking into account the severity of the neurological deficit.

Material and research methods. We examined 113 patients with ischemic stroke aged 44 to 80 years. The study was conducted on the basis of the Department of Neurology. The selection of patients was carried out by random sampling. The diagnosis of ischemic stroke was confirmed by MSCT. The average age of patients with ischemic stroke was $65.9 \pm 0.97$ years, among these patients there were 63 men and 50 women. The severity of neurological deficits was assessed using the NIHSS scale. Among the subgroups, the highest average was in patients with hemodynamic IS, which amounted to 20.5, and the lightest were patients with lacunar stroke.

Research results. Based on the scores, the NIHSS are subdivided into three groups according to the severity of ischemic stroke.

The first group consisted of 22 patients $(19.5 \%)$ with mild stroke (from 3-8 points) (mean score $-6.51 \pm 1.2$ ), in whose clinical picture mild focal neurological symptoms predominated without disturbances of consciousness and signs swelling of the brain.

The second group consisted of 71 patients $(62.8 \%$ ) with moderate stroke (from 9-18 points) (mean score $-16.41 \pm 0.9$ ). All patients in this group had neurological symptoms against the background of mild cerebral disorders, the severity of which ranged from mild changes in consciousness to stunning.

The third group consisted of 20 patients (17.7\%) with severe IS (from 19-28 points) (mean score $-22 \pm 0.54$ ). In patients of this group, against the background of gross neurological defects, impaired consciousness was observed from deep stunning to stupor and coma.

Duplex scanning revealed deformities and atherosclerotic changes in the main arteries of the head in most of the examined patients.

Stenosis of more than $50 \%$ and occlusion of the internal carotid artery was observed in $36(31.86 \%)$ patients. When examining the vertebral arteries, this indicator was found in $8(7.08 \%)$ patients. The average thickness of the intima-media complex was $1.31 \pm 0.19 \mathrm{~mm}$.

The relationship between the indicators of duplex scanning and the severity of the disease was found. In the group of patients with IS of mild severity, $13.6 \%$ of cases showed signs of a decrease in the lumen of the internal carotid artery by more than $50 \%$ without occlusion and in $36.4 \%$ of cases, signs of a reduction in the lumen of the internal carotid artery of less than $50 \%$ were revealed, and in 
other patients, blood flow through the internal the carotid artery was preserved.

With moderate IS in $45.1 \%$ of patients, there was a narrowing of the lumen of the internal carotid artery by less than $50 \%$, while hemodynamically significant stenoses were diagnosed in $31 \%$ of the examined patients, occlusion of the internal carotid artery - in 5.6\%. Stenosis of the lumen of the internal carotid artery was less than $50 \%$ and normal hemodynamics were $45.1 \%$ and $18.8 \%$ of cases, respectively.

In severe IS, stenosis of the internal carotid artery more than $50 \%$ without occlusion and occlusion were observed with almost the same frequency - in 7 and 8 patients ( 35 and $45 \%$ of cases). Attention is drawn to their significantly higher proportion than in patients with moderately severe stroke. Patients with occlusion less than $50 \%$ and with normal hemodynamics accounted for $25 \%$ of cases.

The minimum values of the intima-media complex, indicating a thickening of the intimo-medial complex, were observed in patients with mild IS. In the groups of patients with moderate and severe strokes, the values of the intima-media complex were significantly higher.

Conclusion: Thus, in the acute period of ischemic stroke, a relationship was revealed between the severity of clinical manifestations and hemodynamic disorders. More pronounced hemodynamic changes were found in patients with atherothrombotic IS, in whom thickening of the intima-media complex and atherosclerotic plaques were revealed. With hemodynamic IS, vasospasm was noted. During rheological IS, no characteristic changes were revealed. In lacunar IS and cardioembolic IS, the changes were not pronounced and were characterized only by an increase in the Gosling and Purselo index, the linear blood flow velocity was increased. 
Khikmatullaeva A.S., Ibadullaeva N.S., Nazarova F.N. Research Institute of Virology, Uzbekistan

Introduction. COVID-19 is an infectious disease caused by the SARS-CoV-2 virus. The immune system of body reacts in response to infection by producing specific antibodies to SARS-CoV-2. The determination of antibodies to SARS-CoV-2 is carried out to assess the level of infection in the studied population. Serologic tests to detect antibodies to SARS-CoV-2 can determine the presence of current or past infection. Much research is currently underway to examine the duration of antibodies to SARS-CoV-2 after infection with COVID-19. Individuals who have had COVID-19 develop specific IgG antibodies to SARS-CoV-2. However, the duration of IgG antibodies to SARS-CoV-2 is currently unknown.

Aim of the study. Determine the presence of IgG antibodies to SARS-CoV-2 in COVID-19 reconvalescents.

Materials and methods. The material for the study of antibodies to SARS-CoV-2 was the blood plasma of 121 COVID-19 reconvalescents. Of these, blood plasma was collected 5 months after discharge from the hospital from 7 reconvalescents, after 8 months from 35, after 9 months - 79 reconvalescents. The age of COVID-19 reconvalescents ranged from 17-72 years and the average age was 41 years. All patients with COVID-19 were hospitalized and received inpatient treatment at the clinic of the Research Institute of Virology in the period April-June, August 2020. The diagnosis of COVID-19 in hospitalized patients was confirmed by the detection of SARS-CoV-2 RNA by PCR using the Multi-type Sample DNA/RNA Extraction-Purification Kit (Magnetic beads method) and Novel Coronavirus (2019-nCoV) Nucleic Acid Diagnostic Kit "(PCR-Fluorescence Probing), manufactured by Sansure Biotech Inc., (China) according to the manufacturer's instructions. Determination of IgG antibodies to SARS-CoV-2 in blood serum was carried out using the MAGLUMI 2019-nCoV IgG kit (CLIA) manufactured by Shenzhen New Industries Biomedical Engineering Co., Ltd. (China) according to the manufacturer's instructions.

Results. Detection of IgG antibodies to SARS-CoV-2 in COVID-19 reconvalescents was carried out 5, 8, 9 months after the disease. Most of the COVID-19 reconvalescents were women $-81.0 \%$ of cases, men $-19.0 \%$. The results of the study showed the presence of IgG antibodies to SARSCoV-2 5 months after discharge from the hospital in $100.0 \%$ of cases, after 8 months in $71.4 \%$, after 9 months in $62.0 \%$ of cases.

In $23(19.0 \%)$ COVID-19 reconvalescents, the disease was mild, in $89(73.5 \%)$ cases, it was moderate, and in $9(7.4 \%)$ reconvalescents, the disease was severe. Among COVID-19 reconvalescents with a mild course of the disease, IgG antibodies to SARS-CoV were found in $39.1 \%$ of cases, with a moderate course in $73.0 \%$, and with a severe course of the disease in $89.0 \%$ of cases.

Conclusions. The results of study of IgG antibodies to SARS-CoV-2 in COVID-19 reconvalescents showed the presence of antibodies after 9 months in $62.0 \%$ of cases. To determine the duration of the retention of IgG antibodies to SARS-CoV-2, it is necessary to examine COVID-19 reconvalescents over time. 


\title{
PECULIARITIES IN THE PHYSICAL DEVELOPMENT OF CHILDREN WITH FETAL INFECTION WITH CYTOMEGALOVIRUS, HERPES SIMPLEX 1 AND 2 TYPES, CHLAMYDIA TRACHOMATIS AND ASSOCIATED INFECTION
}

\author{
Agzamova Shoira \\ professor of the department of Outpatient Medicine, \\ Physical Training of the Tashkent Pediatric Medical Institute, \\ DM, Tashkent City, Uzbekistan \\ e-mailshoira agzamova@mail.ru \\ Tashpulatova Fatima \\ head of the department of Phthisiology and Pulmonology of the \\ Tashkent Pediatric Medical Institute, DM, Tashkent city, Uzbekistan, \\ e-mail fatima2263@mail.ru \\ Akhmedova Firuza \\ Ph.D., assistant of the department of Outpatient Medicine, \\ Physical Training of the Tashkent Pediatric Medical Institute, \\ Tashkent city, Uzbekistan, \\ e-mail feruz.munisa@mail.ru
}

Annotation: Results of the assessment of physical development of children with fetal infection with cytomegalovirus, Herpes simplex virus 1,2 types, Chlamydia trachomatis and associated infection from the moment of birth to 4 years showed, we revealed 3.0 and 2.7 times more often growth retardation; 6 and 1.9 times more often registration of weight deficit. Only infected children had characteristic risk of protein-energetic deficit in nutrition and PEDN /moderate exhaustion.

Key words: fetal infection, children from birth to 4 years old, physical development

Relevance. Among a great number of infectious diseases of children Cytomegalovirus (CMV), Herpes, urogenital Chlamydia take a special place, which is linked with variety of ways of transmission (fetal infection, fecal-oral, air-drip, contact, sexual, and other ways), difficulties in isolation of the agent(s), peculiarities in response of incompletely formed immune system of a child's organism [1, $2,3,4,5]$.

The objective. To study peculiarities of physical development of children with fetal infection with CMV, Herpes Simplex 1 and 2 types (HSV), Chlamydia trachomatis (Ch. trachomatis) and associated infection from the moment of birth to 4 years old.

Material and research methods. For the assessment of physical development of the children with fetal infection with CMV, HSV, Ch. trachomatis and associated infection we performed a monitoring of 132 children from the moment of their birth $(n=112)$ and children 20 days old born by mothers with chronic latent-persisting TORCH infections and burden of obstetric-gynecological history (comparison group, $n=20$,) till 4 years old within the period from 2006 to 2010: In compliance with the objective, distribution of the children of the basic group was performed taking into account the agents of fetal TORCH infection: $1^{\text {st }}$ group with fetal infection with CMV $(n=30), 2^{\text {nd }}$ group with fetal infection with HSV 1, 2 types $(n=25), 3^{\text {rd }}$ group with fetal infection with $\mathrm{Cl}$. trachomatis and associated infection ( $\mathrm{n}=17)$ (CMV, HSV, ureaplasma). Control group involved non-infected children $(\mathrm{n}=40)$.

Results and discussion. In the age category from birth to 6 months there was notable growth retardation (between $-2 z$ and $-3 z$ ) 2.3, 2.7, 2.2 and 2.2 times more often, respectively in the children of the $1^{\text {st }}, 2^{\text {nd }}, 3^{\text {rd }}$ groups and comparison group in relation to that value in the control group (fig. 1). 


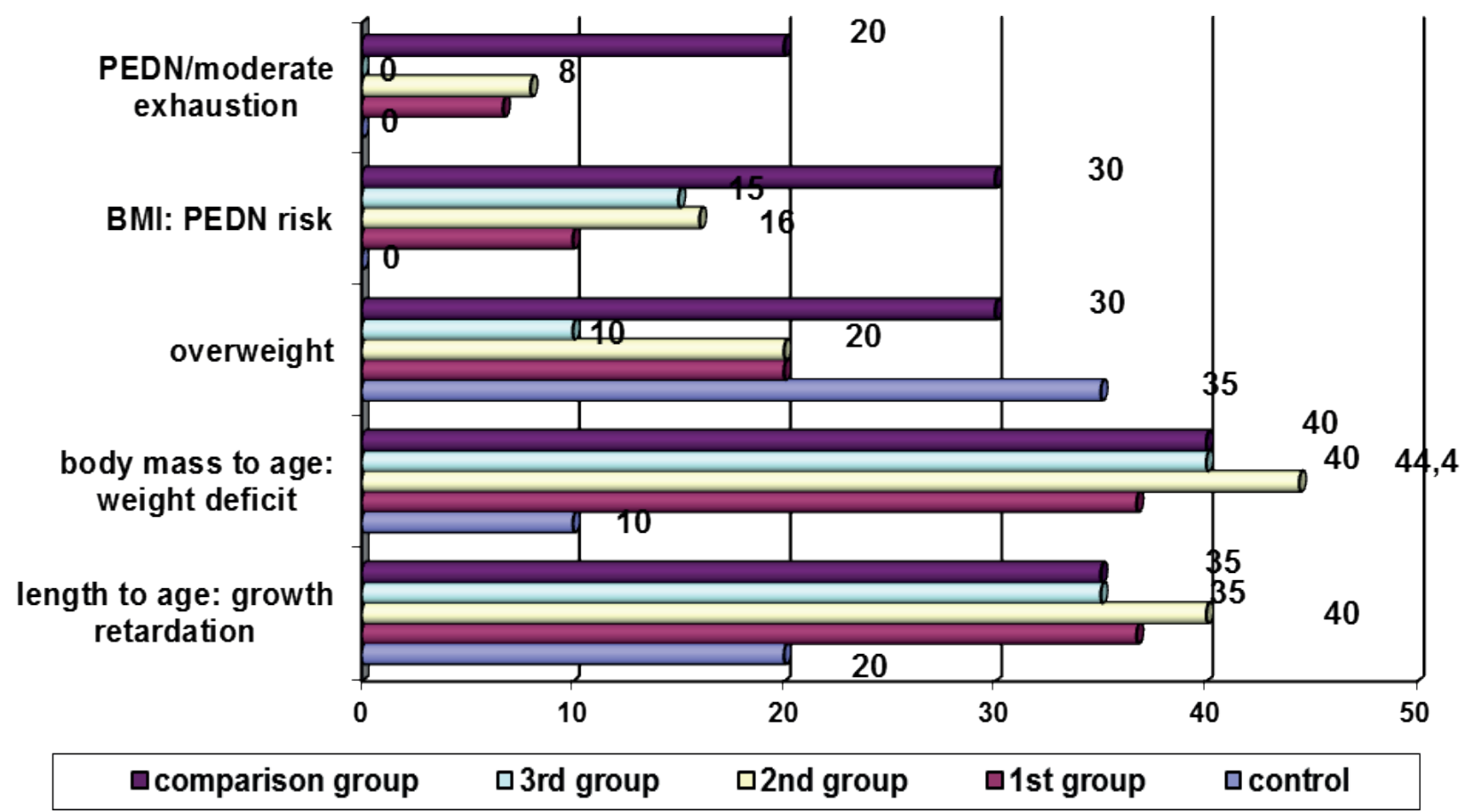

Figure 1. Curves of growth and development of children in the studied groups in the age category from birth to 6 months $(\%)$

According to the values of body mass to age in that age category we revealed reliable differences in weight deficit (between $-2 \mathrm{z}$ and $-3 \mathrm{z}$ ), rise of its prevalence among children with fetal infection and comparison group $\left(\mathrm{p}<0.05, \mathrm{p}<0.01, \mathrm{p}<0.05, \mathrm{p}<0.05\right.$, respectively for the $1^{\text {st }}, 2^{\text {nd }}, 3^{\text {rd }}$ groups and comparison group). However, the greatest prevalence of overweight was characteristic for the children in the control group, while the least one for the children in the $3^{\text {rd }}$ group $(p<0.05)$.

Low values of BMI, interpreted as protein-energetic deficit of nutrition risk between $-1 \mathrm{z}$ and $-2 \mathrm{z}$ and moderate exhaustion between $-2 \mathrm{z}$ and $-3 \mathrm{z}$, were characteristic for the children in basic group (13.3\% and $5.3 \%$, respectively) and comparison group (30\% and 20\%, respectively). These characteristics were absent in the control group.

Similar dynamics in growth retardation was registered in the age category from 6 months to 2 years with reliable rise of its prevalence among the children of the $1^{\text {st }}$ and $2^{\text {nd }}$ groups $(\mathrm{p}<0.05$, $\mathrm{p}<0.05$, respectively) compared to the control. Children of the $3^{\text {rd }}$ group and comparison group had a probability of growth retardation 3.5 and 2.9 times higher, respectively, than children in the control group. In the category mass to age weight deficit was registered only among the children with fetal infection $\left(25.9 \%, 20.0 \%\right.$ and $23.5 \%$, respectively in the $1^{\text {st }}, 2^{\text {nd }}$, and $3^{\text {rd }}$ groups) with prevailing of the parameter among the children in comparison group (30\%). Diametrically opposite characteristic of overweight (between $+2 z$ and $+3 z$ ) was observed only among the children $(28 \%)$ in the control group. PEDN risk according to BMI was also characteristic for the children with fetal infection $(18.5 \%$, $15.0 \%$ and $11.8 \%$, respectively in the $1^{\text {st }}, 2^{\text {nd }}$, and $3^{\text {rd }}$ groups) and children suspected to have fetal infection (comparison group, 20\%).

In the age category from 2 to 4 years old the prevalence of growth retardation with some leveling keeps its leading position among the infected children and children in comparison group. Prevalence of weight deficit in the category mass to age tended for decrease in comparison with two previous age periods. However, probability of the development of PEDN risk increased a little bit among the children with fetal infection.

Thus, physical development of the children is characterized by its own unique and actual in strictly certain time patterns of development, it is asynchronous and regular. According to the law of irregular changes in growth velocity the period of the first extension corresponds to age period from birth to one year, while the period of the first overweight or the first "becoming round" from $1^{\text {st }}$ to $4^{\text {th }}$ years of life; it is characterized by weight gaining prevailing over length.

Conclusion. Fetal infection has a significant effect on differentiation of length/height and body mass in children in postnatal period. In the age range from birth to 6 months and from 6 months to 
2 years old we revealed 3.0 and 2.7 more often growth retardation. Six and 1.9 times more often we registered weight deficit, respectively in the age categories from birth to 6 months and from 2 to 4 years old. Only infected children were characterized by PEDN risk and PEDN/ moderate exhaustion. We paid attention to high prevalence of disorders in growth among the children in comparison group. Probably, revealed disorders are infection-determined and we cannot exclude the probability of fetal infection.

\section{References:}

1. Agzamova Sh. A. Factor analysis of cause-effect relationship of fetal infections of children by the agents of TORCH - complex. European science review, no. 5-6, 2015, pp. 43-46.

2. Agzamova Sh.A., Akhmedova D.I., Daminov T.O. Factor model of TORCH infection effect on the newborns’ viability. European Journal of Natural History. - 2010. - № 5 - P. 4-7

3. Belanger BG, Lui F. Embryology, Teratology TORCH. In: Stat Pearls. Treasure Island (FL): StatPearls Publishing; July 26, 2020.

4. Leung KKY, Hon KL, Yeung A, Leung AKC, Man E. Congenital infections in Hong Kong: an overview of TORCH. Hong Kong Med J. 2020;26(2):127-138. doi:10.12809/hkmj198287

Pereira L. Congenital Viral Infection: Traversing the Uterine-Placental Interface. Annu Rev Virol. 2018 Sep 29;5(1):273-299. [PubMed] 


\title{
QUANTITATIVE ANALYSIS OF “SILYBUM MARIANUM” LIQUID EXTRACT.
}

Tashkent Pharmaceutical Institute. Allanazarova Mohira, student of the Faculty of Industrial Pharmacy,

\begin{abstract}
Annotation:In pharmaceutical technology, methods are known for preparing medicines and substances based on the amount of BAS (carsil, silibor,silybum, silybum etc.), as well as individual substances from fruits spotted silybum marianum, however, the disadvantage of the known methods is the complexity technological process and low yield of the target product. In addition, before the present time both in domestic and foreign literature emphasized above all the importance of the three main active ingredients milk thistle fruits - silybin, silidianin and silicristin, which determine hepatoprotective, antioxidant,membrane stabilizing properties of drugs based on raw materials of thisplants Relevance of the topic.
\end{abstract}

Key words:Silybum marianum,Cholemarin,fruits,antioxidant,membrane,materials,

Currently, the fruits of the milk thistle [Silybum marianum(L.) Gaertn. this Asteraceae - Astrovykh] are widely used in Russia and abroad for the production of such valuable hepatoprotective drugs as Silibum, Karsil, Legal, Silibor, Gepabene, etc. The uniqueness of these drugs lies in the fact that their hepatoprotective properties are due to a new group of biologically active compounds (ALS ) flavolignans, in particular, silybin, silidianin and silicristin. The mechanism of action of these BAS includes a decrease in phospholipid peroxidation in liver tissue and an increase in the activity of antioxidant enzymes such as catalase and superoxide dismutase, as well as stimulation of liver cell regeneration. It is important to emphasize that hepatoprotectors based on the fruits of milk thistle are used not only for the treatment of liver pathology, but also as an auxiliary therapy for many infectious lesions (chronic bronchitis, chlamydia, toxoplasmosis, etc.), as well as for the prevention of various diseases. resulting from exposure to the body of adverse environmental factors. However, the lack of a sufficient range of domestic analogues and the high cost of imported drugs do not allow satisfying the urgent need of the population for this group of drugs. Huge opportunities for the creation of modern hepatoprotectors based on flavolignans of milk thistle are available in the Samara region, where the largest industrial raw material base in the Russian Federation has been created. Thus, the development of domestic, effective, safe, affordable hepatoprotective phytopreparations, applicable in pediatric practice, seems relevant and promising both in scientific and practical terms. The purpose and objectives of the study. The purpose of this work is to study the pharmacognostic and analytical aspects of the creation of 21 . Comparative study of the chemical composition of fruits, meal, bagasse of mottled raspberry cultivated in the Samara region. 2. Substantiation of the method for obtaining a new hepatoprotective drug "Cholemarin". 3. Development of methods for the qualitative and quantitative analysis of the new hepatoprotective drug "Cholemarin". 4. Development of methods for the qualitative and quantitative analysis of the hepatoprotective drug "Milk thistle syrup". 5. Development of numerical indicators for new hepatoprotective drugs "Cholemarin" and "Milk thistle syrup". 6. Development of draft regulatory documents for FSP "Cholemarin" and FSP "Milk thistle syrup".

Scientific novelty.

As a result of studying the chemical composition of milk thistle fruit spotted, cultivated in the Samara region, identified and identified silybin, silidianin, silicristin, as well as for the first time obtained and characterized the individual substance flavolignan (one of main biologically active compounds) 2,3-dehydrosilybin. Revealed that 2,3-dehydrosilybin has a pronounced antioxidant effect that makes it possible to classify this flavolignan as one of the main biologically active milk thistle fruit compounds. To establish the structure and determination of the physicochemical properties of dehydrosilybin using UV spectrometry, 1H-NMR spectroscopy and mass spectrometry, and various chemical transformations. Based on the principle of unification developed unified methods of qualitative and quantitative analysis of preparations "Cholemarin" and "Milk thistle syrup" using thin layer chromatography and direct spectrophotometry and State standard sample (GSO) of silybin. Scientifically based expediency of using fruit meal (after extraction with freon-12) for obtaining, hepatoprotective drugs. Comparative phytochemical research of fruits, meal and fruit pulp, extract, cholemarine and milk thistle syrup.Practical significance. 
1. The technology of obtaining milk thistle extract liquid and drug "Cholemarin" (maximum extraction is achieved main BAS fruits of milk thistle from native fruits and fat-free raw materials) and methods of qualitative and quantitative analysis, allowing to determine the content of the sum of flavolignans in the raw material and preparations.

2. Received RF Patent for invention No. 2209063 "Method of obtaining a substance with an antioxidant effect "according to application No. 2002103533 from 08.02.2002

3. Methods of qualitative and quantitative analysis have been developed. preparations "Cholemarin" and "Milk thistle syrup" using TLC analysis and direct spectrophotometry.

4. The numerical indicators of the drugs "Cholemarin", "Milk thistle syrup ": the content of the sum of flavolignans, the dry residue, the concentration of alcohol, the expiration date is set.

5. The expediency of using the developed drugs for the basis of the fruits of mottled mottled "Cholemarin" and "Milk thistle syrup" in medical practice as hepatoprotective drugs.

CONCLUSIONS 1. As a result of a comparative study of the chemical composition of fruits, meal, milk thistle bagasse [Silybum marianum (L.) Gaertn.], Isolated and identified using UV, 1H-NMR spectroscopy and mass spectrometry, as well as various chemical transformations of flavolignans, silybin, silidianin , silicristin. 2.2,3-dehydrosilybin has been isolated for the first time from the fruits and fat-free raw materials of milk thistle cultivated in the Russian Federation and the CIS countries. 


\title{
ESTIMATION OF PARAMETERS OF REMODELING OF THE RIGHT HEART REGIONS AND THE LEVEL OF PULMONARY HYPERTENSION IN PATIENTS WITH INTRA-ABDOMINAL HYPERTENSION
}

Azizova F.F., Sabirov J.M., Atakhanova L.E. Center for the development of professional qualifications medical workers, Uzbekistan

\begin{abstract}
The study of the regularities of the effect of increased IAP (Intra-abdominal pressure) on the work of the heart and blood vessels makes it possible to predict pathological changes in the activity of vital organs associated with hemodynamic disturbances.
\end{abstract}

Keywords. Remodeling, right heart, IAP (Intra-abdominal pressure)

Introduction Increased intra-abdominal pressure shifts the diaphragm high up and significantly increases the average intrathoracic pressure, which is reflected in the tone of large vessels and the work of the heart $[1,3]$. The increased pressure in the chest cavity significantly reduces the severity of diastolic filling of the ventricles, changes the pressure gradient on the myocardium, increases the pressure in the pulmonary capillaries, reduces the stroke volume of the heart, and reduces venous return $[2,4,5]$. Despite the increasing tachycardia, cardiac output is significantly reduced. The total peripheral vascular resistance increases with increasing intra-abdominal hypertension.

The most pronounced changes occur on the part of the cardiovascular system. An increase in pressure in the abdominal cavity significantly slows down blood flow through the inferior vena cava and significantly reduces the return of venous blood.

Goal. Assessment of the parameters of remodeling of the right heart and the level of pulmonary hypertension in patients with intra-abdominal hypertension.

Material and methods. The study was based on a clinical and laboratory examination of 170 patients in whom IAP rose during and after surgery and 40 apparently healthy people of comparable age for an adequate assessment of laboratory data.

In the study of RV (Right ventricle) systolic function, the following parameters were studied: RV diameter in diastole (RVD), RV outlet tract diameter (RVOD), RV anterior wall thickness at diastole, diameter of the pulmonary artery (PA) and its branches, PA systolic pressure (PASP).

Results and its discussion. The indices of the right heart function are presented in Table 1 . When comparing the indices of the right ventricle in patients of subgroup 1, consisting of patients with increased intra-abdominal pressure of I-II degrees compared with subgroup 3, consisting of patients after resolved syndrome of intra-abdominal hypertension, reliable signs of hypertrophy were revealed $(0.74 \pm 0.11$ and $0.49 \pm 0.07, \mathrm{p}<0.001)$ compared with subgroup $3(0.66 \pm 0.08$ and $0.49 \pm 0.07$, respectively, $\mathrm{p}<0.001$ ). When comparing the 1 st and 2 nd subgroups, a more pronounced thickening of the pancreatic wall was found in the group of patients with a strangulated ventral hernia $(\mathrm{p}<0.01)$.

Indicators of remodeling of the right ventricle, pulmonary artery and

Table 1 pulmonary hypertension

\begin{tabular}{|l|c|c|c|}
\hline \multirow{2}{*}{\multicolumn{1}{|c|}{ Indicators }} & \multicolumn{3}{|c|}{ Main group ( $\mathrm{n}=96)$} \\
\cline { 2 - 4 } & 1 subgroup ( $\mathrm{n}=12)$ & 2 subgroup ( $\mathrm{n}=50)$ & 3 subgroup ( $\mathrm{n}=34)$ \\
\hline RVD, cm & $2,85 \pm 0,53$ & $2,55 \pm 0,39$ & $2,05 \pm 0,23$ \\
\hline RVOT, cm & $2,63 \pm 0,36$ & $3,13 \pm 0,37 * * *$ & $2,57 \pm 0,28^{* * *}$ \\
\hline PA, cm & $2,74 \pm 0,27$ & $2,63 \pm 0,20$ & $2,62 \pm 0,16$ \\
\hline PA right branch & $1,93 \pm 0,38$ & $1,82 \pm 0,12$ & $1,51 \pm 0,12$ \\
\hline PA left branch & $1,72 \pm 0,18$ & $1,66 \pm 0,13$ & $1,58 \pm 0,09$ \\
\hline SPPA, mm Hg & $31,16 \pm 1,61$ & $35,04 \pm 0,87$ & $34,38 \pm 0,80^{*}$ \\
\hline
\end{tabular}


Note:

* - differences relative to the comparison group data are significant $(*-p<0,05, * *-p<0,01$, $* * *-p<0,001)$

In patients with AP (acute peritonitis), subgroup 2) compared with subgroup 1, RV diameter (2.55 \pm 0.39 and $2.05 \pm 0.23, p>0.05)$ and RVOT $(2.63 \pm 0.37$ and $2,57 \pm 0.28, p<0.001)$ are statistically significantly expanded. The diameters of the pancreas and VTS in patients of group 1 also exceeded these parameters than in patients of subgroup 3 and amounted to $2.85 \pm 0.53$ and $2.05 \pm 0.23(\mathrm{P}>0.05)$ and $2.63 \pm 0.36$ and $2.57 \pm 280$, respectively $(\mathrm{p}>0.05)$.

The PA diameter is enlarged both among patients of subgroup $1(2.74 \pm 0.27$ and $2.02 \pm 0.16, \mathrm{p}>$ $0.05)$, and in the subgroup of patients with AP $(2.63 \pm 0.20$ and $2,02 \pm 0.16, p>0.05)$ compared to subgroup 3.

SPPA (systolic pressure in the pulmonary arteria) in the 1st and 2nd groups of patients (31.16 \pm 1.61 and $35.04 \pm 0.87$, respectively) statistically insignificantly exceeded this indicator in the 3rd subgroup $(34.38 \pm 0.80, \mathrm{P}<0.05)$. The level of SPPA in patients of subgroup 1 was higher than in patients of subgroup $2(\mathrm{p}>0.05)$.

PH (pulmonary hypertension), which was diagnosed in patients of subgroups 1 and 2, was in most cases of a moderate nature, which corresponds to the data of many authors. PH was detected in $85 \%$ of patients in subgroup $1,83 \%$ of patients in subgroup 2, and in $27 \%$ of patients in subgroup 3 . Severe $\mathrm{PH}$ (more than $50 \mathrm{~mm} \mathrm{Hg}$ ) was detected only in $21.8 \%$ of patients in subgroup 1, in $5.8 \%$ of patients in group 2, and in none of patients in subgroup 1.

Thus, analyzing the parameters of the pancreas in patients of groups 1 and 2, it was revealed that they had significant structural changes in comparison with patients in the control group: pancreatic dilatation, dilatation of the pulmonary artery and its branches, pulmonary hypertension.

Processes of RV remodeling in patients of subgroup 1 and subgroup 2 occur already with a moderate increase in PAP

More significant and reliable signs of remodeling of the right heart were revealed in patients of subgroup 1.

In order to study the relationship between the severity of IAH and the parameters of RV remodeling, a correlation analysis was carried out between SPPA and RVD in patients of groups 1 and 2.

As a result of the performed correlation analysis using Spearman's correlation, it was revealed that a significant linear correlation was observed between the values of SPPA and RVD in patients of the 1 st subgroup $(\mathrm{r}=0.65, \mathrm{p}<0.001)$ and SPPA $-\mathrm{p}>0.5, \mathrm{p}<0.05)$ In patients of group 2 , this relationship was moderate (RVD - $\mathrm{r}=0.33, \mathrm{p}<0.001$; SPPA - $\mathrm{r}=0.4, \mathrm{p}<0.001$ ).

Output. The results obtained showed that the degree of systolic shortening of the right ventricle, depending on the degree of IAH (intra-abdominal hypertension), practically does not depend on much and is unreliable ( $p>0.05)$. Only RVCL (right ventricle cavity length) significantly decreases $(p<0.001)$ depending on the degree of IAH.

\section{References}

1. Brush K. A. Abdominal compartment syndrome: the pressure is on // Nursing. - 2007. - №31. - P. 37-40.

2. Burchard K.W., Ciombor D.M., McLeod M.K. et al. Positive end expiratory pressure with increased intra-abdominal pressure // Surg. Gyn. Obstet. - 2005. - Vol. 161. - P. 313-318.

3. Burrows R, Edington J, Robbs JV. A wolf in wolf's clothing--the abdominal compartment syndrome // S Afr Med J. - 2015. - Vol.85 (1). - P. 46-8.

4. Caldwell C.B., Ricotta J.J. Changes in visceral blood flow with elevated intraabdominal pressure // J. Surg. Res. - 2007. - V.43, №1. - P. 14-20.

5. Cheatham M. L., Malbrain M., Kirkpatrick A. Results from the International Conference of Experts on Intra-abdominal Hypertension and Abdominal Compartment Syndrome. II. Recommendations // Intens. Care Med. - 2007. - Vol.33, №6. - P. 951-962. 


\title{
CLINICAL FEATURES OF COVID-19 DEPENDING ON THE SEVERITY OF THE DISEASE
}

\author{
Bayjanov A.K., Khikmatullaeva A.S., Samatova I.R. \\ Research Institute of Virology, Tashkent
}

The disease caused by a new virus strain from the SARS-CoV-2 genus of coronaviruses can proceed without clinical manifestations (asymptomatic), in a mild form and in a severe form with intoxication and inflammatory processes of the respiratory tract with a risk of death, but the complete clinical picture still remains not clear (CDC, 2020).

To study the clinical characteristics of the course of COVID-19, depending on the severity of the course of the disease, a study was carried out in 204 patients hospitalized in the clinic of the Research Institute of Virology of the Republican Scientific and Practical Medical Research Center of EMIPZ.

According to the clinical course of the disease, the patients were divided into 3 groups: patients with mild course 16 (7.8\%), moderately severe course $119(58.3 \%)$ and severe course $69(33.8 \%)$ of the disease. The age of the patients was in the range of 18-76 years (mean age was 48.7 years).

The most common symptoms of severe COVID-19 were weakness $(92.7 \%)$, lethargy $(42.0 \%)$, shortness of breath $(91.3 \%)$, shortness of breath $(79.7 \%)$, which were less frequent in mild $(6.25 \%$, $0 \%, 12.5 \%, 18.7 \%)$ and moderate-severe $(90.0 \%, 37.0 \%, 37.0 \%, 17.6 \%)$ forms of the disease.

In the severe form of the disease compared with the moderate and mild forms of the disease, there was a significant difference in chest pain $(42.0 \%, 23.5 \%$ and $6.25 \%)$, respectively.

Fever, although more $(42.0 \%)$ occurred in the severe form compared with the moderate-severe form $(36.9 \%)$ of the disease, there was no significant difference. With a mild form, it was $25.0 \%$. Also, cough, sore throat, anxiety, and diarrhea were not correlated with disease severity.

It turned out to be interesting that the frequency of occurrence of anosmia (loss of smell) and agenesis (loss of taste) naturally decreased as the disease progressed (in mild, moderate and severe disease, respectively, $43.7 \%, 21.0 \%, 11.6 \%$ and $31.2 \%, 24.3 \%, 10.1 \%$ ).

Among the examined patients, the incidence of pneumonia directly correlated with the severity of the disease. In patients with a severe course of the disease, pneumonia was observed in $86.9 \%$, compared with a mild (18.7\%) and moderately severe $(54.6 \%)$ course of the disease, with $\mathrm{P}<0.05$.

Thus, coronavirus infection is characterized by polymorphism of clinical symptoms, manifested with varying degrees of severity depending on the severity of the course of the disease, which requires further research due to the presence of a high risk of complications and consequences of the disease. 


\title{
PHILOLOGICAL SCIENCE
}

\section{ESSENTIAL CUES FOR WRITING A SUCCESSFUL ESSAY}

\author{
Axmedova Sanobar Adilbekovna, \\ Sabirova Sadoqat Davlatmuratovna, \\ Atajanova Iroda Ortiqovna
} EL teachers, School N_18, Urgench city, Khorezm region.

\begin{abstract}
Annotation: Many scientists suggest different approaches to effective essay writing. In this article we will discuss essay writing process and methods that improve writing skills. This article will consider techniques that can be used for the further development of effective writing.

Key words: essay, writing, technique, method, approach, steps in writing.
\end{abstract}

Writing an essay, without doubt, often seems to be a dreaded task among students. Whether the essay is for a scholarship, a class, or maybe even a contest, many students often find the task overwhelming. While an essay is a large project, there are many steps a student can take that will help break down the task into manageable parts. Following this process is the easiest way to draft a successful essay, whatever its purpose might be. According to Kathy Livingston's Guide to Writing a Basic Essay, there are seven steps to writing a successful essay:

Pick a topic. You may have your topic assigned, or you may be given free reign to write on the subject of your choice. If you are given the topic, you should think about the type of paper that you want to produce. Should it be a general overview of the subject or a specific analysis? Narrow your focus if necessary. If you have not been assigned a topic, you have a little more work to do. However, this opportunity also gives you the advantage to choose a subject that is interesting or relevant to you. First, define your purpose, is your essay to inform or persuade? Once you have determined the purpose, you will need to do some research on topics that you find intriguing. Think about your life. What is it that interests you? Jot these subjects down. Finally, evaluate your options. If your goal is to educate, choose a subject that you have already studied. If your goal is to persuade, choose a subject that you are passionate about. Whatever the mission of the essay, make sure that you are interested in your topic.

Prepare an outline or diagram of your ideas. In order to write a successful essay, you must organize your thoughts. By taking what's already in your head and putting it to paper, you are able to see connections and links between ideas more clearly. This structure serves as a foundation for your paper. Use either an outline or a diagram to jot down your ideas and organize them. To create a diagram, write your topic in the middle of your page. Draw three to five lines branching off from this topic and write down your main ideas at the ends of these lines. Draw more lines off these main ideas and include any thoughts you may have on these ideas. If you prefer to create an outline, write your topic at the top of the page. From there, begin to list your main ideas, leaving space under each one. In this space, make sure to list other smaller ideas that relate to each main idea. Doing this will allow you to see connections and will help you to write a more organized essay.

Write your thesis statement. Now that you have chosen a topic and sorted your ideas into relevant categories, you must create a thesis statement. Your thesis statement tells the reader the point of your essay. Look at your outline or diagram. What are the main ideas? Your thesis statement will have two parts. The first part states the topic, and the second part states the point of the essay. For instance, if you were writing about "Internet and its impact on the upbringing of the youth", an appropriate these statement would be, "Internet has become an indispensable part of the lives if the youth, that has invaded their whole brain."Write the body. The body of your essay argues, explains or describes your topic. Each main idea that you wrote in your diagram or outline will become a separate section within the body of your essay. Each body paragraph will have the same basic structure. Begin by writing one of your main ideas as one introductory sentence. Next, write each of your supporting ideas in sentence format, but leave three or four lines in between each point to come back and give detailed examples to back up your position. Fill in these spaces with relative information that will help link smaller

January-February, 2021 
ideas together.Write the introduction. Now that you have developed your thesis and the overall body of your essay, you must write an introduction. The introduction should attract the reader's attention and show the focus of your essay. It would be astounding success, if you begin it with an attention grabber. You can use shocking information, dialogue, a story, a quote, or a simple summary of your topic. Whichever angle you choose, make sure that it ties in with your thesis statement, which will be included as the last sentence of your introduction. Write the conclusion. The conclusion brings closure of the topic and sums up your overall ideas while providing a final perspective on your topic. Your conclusion should consist of three to five strong sentences. Simply review your main points and provide reinforcement of your thesis. Add the finishing touches. After writing your conclusion, you might think that you have completed your essay. Wrong. Before you consider this is a finished work, you must pay attention to all the small details. Check the order of your paragraphs. Your strongest points should be the first and last paragraphs within the body, with the others falling in the middle. Also, make sure that your paragraph order makes sense. If your essay is describing a process, such as how to make a pancake, make sure that your paragraphs fall in the correct order. Review the instructions for your essay, if applicable. Many teachers and scholarship forms follow different formats, and you must double check instructions to ensure that your essay is in the desired format.

Finally, review what you have written. Reread your paper and check to see if it makes sense. Make sure that sentence flow is smooth and add phrases to help connect thoughts or ideas. Check your essay for grammar and spelling mistakes.

Congratulations! You have just written a great essay.

\section{Bibliography:}

1.Burlakova W. Writing allowance. L.Uchpedgiz, 1962, 216 p.

2.Passov E.I. Fundamentals of teaching foreign languages. M.: Russian language, 1977, 214 p.

3.Elbow, P. (1988). Writing without teachers. Oxford University Press, USA. 


\title{
SOME FEATURES OF THE TRAINING OF CONFERENCE INTERPRETERS IN THE EUROPEAN UNION
}

\author{
Khurshida Khodjayeva \\ Senior lecturer at the department of \\ Romano-Germanic languages at UWED
}

\begin{abstract}
Annotation: The article sums up to consider the features of professional preparation of prospective translators, which relate main activities accomplished by the interpreters. The ultimate condition of goals can be the following tasks: more deeply considering activity of translators, and namely the activity of linguistic analysis of discourse; the foreign language communication; translation (oral, written, consecutive, simultaneous); exposure of essence of the methods to the process of preparing the future interpreters and translators.

Key words: Joint-work of conference translation of the CEU, countries of Benilux, situation in Southeastern Africa, mass media of Tanzania in the southeastern Africa, UN Security Council, Red Cross, Common Service of Conference Interpretation, blind cabin, EU.
\end{abstract}

Everyone knows that during the period of globalization there is an intensification of international contacts in the political, trade, economic, cultural and humanitarian spheres. Therefore, the issues of improving the training of translators and interpreters are of particular relevance. As it is clear, interpretation is divided into consecutive and simultaneous translations.

We would like to bring to your attention some of the features of training conference interpreters for providing consecutive and simultaneous interpreting (traduction consécutive et simultané) in the European Union. In the first case, the interpreter translates as soon as the speaker finishes his thought, in the second case, the interpreter announces the translation as information arrives through the headphones.[3]

6 months are given for the training of conference interpreters in the CES, which are designed to provide a language combination for translation into 23 languages of the EU member states. The lesson is conducted by active specialists in translating, they are called trainers. The training of translators is provided by the Service commun Interprétation-conférences.

Candidates are selected based on interviews, written and oral examinations. Everyone must have a university degree and be fluent in one or two EU languages. At the same time, during the translation, the language of repulsion is considered a foreign language, the language of the parish - the native language.

During the first month, the skills of concentration of thought, analytical thinking and presentation of thoughts in a natural and elegant form without taking notes are being worked out. Speakers are invited to the classes, speaking in different languages, using different styles of presenting thoughts, with their own emotional characteristics. The texts at the beginning are short and uncomplicated, which gradually gain volume and become more complex. Here the task is set to filter information and highlight the main and secondary elements.

For the second month, the same recording skills are being developed. Trainers will show you what to write down and how to label them. Words are written without vowels, for example: Constitution, gives us cnst; President, prsdnt, chair; Prime Minister, prm-mnstr, PM.

For the third month, the improvement of consecutive translation from passive to active languages is being worked out.

For the fourth month, a consecutive translation into a second active language from the native language is being worked out.

The fifth month is devoted to the gradual transition to simultaneous interpretation. Exercises consist in listening to information, analyzing it and dubbing the translation simultaneously with the speaker. In this case, the speaker's speech goes to the translator through headphones, and the translation goes to the listeners through the translator's microphone. In this case, the main attention should be paid to the thoughts of the speaker, and not to his words.

The sixth month is devoted to training in the "silent booth", where everything happens in a natural environment, only the interpreter's speech goes to the examiner, and not to the conference participants.

What is the status of this issue in the UWED?

All our graduates who get a job at the Ministry of Foreign Affairs, MIFT and the Ministry of

January-February, 2021 
Internal Affairs face this challenge. In 2017-2018 academic year a certain amount of work has been carried out in this direction. The course program, timetable and related teaching materials have been drawn up. A group of 18 people has been formed, who are excellent students of 1-5 courses. All are prize-winners and winners of the Republican Olympiads among students of lyceums and colleges, as well as universities of Uzbekistan. It turned out that all of 18 people are students of the Faculty of International Relations. [4]

Interpretation classes were held twice a week and translation classes once a week from 14.30. Interpreting classes were conducted by Art. Rev. French language RGT B. Abdurakhmanov (7 years of translation experience in Algeria), in translation - teacher Z. Ruzieva (7 years of translation experience at UzA). Classes were conducted on an hourly basis.

To date, certain results have been achieved in interpretation. Students mastered the primary skills of oratory, memorizing the speech of the speaker during consecutive translation, taking notes in their native language, keeping abbreviated notes by throwing in vowels, using symbols.

In terms of translation, students mastered the technique of translating political texts, the most common expressions and clichés. In doing so, the main emphasis is on the grammatical requirements in order to achieve correct and adequate translation from French and into French.[2]

In addition, we have developed the following topics:

1. Place of Uzbekistan in the world community.

2. Place of Uzbekistan in French foreign policy.

3. Place of France in the foreign policy of Uzbekistan.

4. Priority directions of Uzbekistan's foreign policy.

5. Mechanisms for promoting the national interests of Uzbekistan.

6. Foreign ministries of the leading states of the world.

7. Presidential, parliamentary and monarchical forms of government.

8. Relations between Uzbekistan and EU member states.

9. Diplomatic missions of the Republic of Uzbekistan.

10. Tourism and investment potential of Uzbekistan.

To proceed with this work, attention is paid to the following:

One of the stages in the preparation of translators is the development of the basic memory of students. Texts for the development of reference memory should be embossed and contrasting. They are prepared by the trainer according to both current European (Appendix \# 1) and fictional scenarios. Sometimes distant African or Asian countries such as Kenya, Tanzania (Appendix \# 2), Mongolia (Appendix \# 3), etc. are taken as an example.

\section{However, there are certain problems:}

1. Classes were conducted on the fourth lesson, and the students come tired. It is advisable to organize classes in the morning.

2. Students come to class irregularly and reluctantly. Additionally, it would be better that translation classes will be added in the mandatory curriculum of the University.

3. It is difficult to get them interested in translation activities, everyone wants to be diplomats. It is necessary to conduct a conversation with them at the level of the UWED leadership in order to raise motivation.

4. It is difficult to work with students of different courses who have different levels of French and general level of training. It is advisable to divide the group into 2 parts, combining 1-2 courses and 3-4 courses.

5. Provide for a different system of remuneration for the coach-translator, which differs from teaching a foreign language.

\section{Appendix \# 1}

There are currently 28 countries in the EU. To list them without classification is not an easy task. We tried to resolve this issue by dividing them according to linguistic and other characteristics.

\section{Benelux countries:}

1. Belgium

2. Netherlands

3. Luxembourg

Countries speaking Romance languages:

4. France

5. Italy 

6. Spain
7. Portugal

German speaking countries:
8. Germany
9. Austria

English-speaking countries:

10. United Kingdom

11. Ireland

\section{Scandinavian countries:}
12. Sweden
13. Finland
14. Denmark

Baltic countries:
15. Latvia
16. Lithuania
17. Estonia

\section{Countries of Eastern Europe}

18. Poland

19. Hungary

20. Romania

21. Bulgaria

22. Czech Republic

23. Slovakia

24. Slovenia

Balkan countries:

25. Greece

26. Croatia

Island states:

27. Cyprus

28. Malta

\section{Appendix \# 2}

\section{Towards the situation in southeast Africa}

According to Tanzanian media reports, in southeast Africa, the invasion of multinational companies has intensified in several countries of the region. At the same time, forests and cultivated fields of local residents are mercilessly destroyed, where the construction of large industrial enterprises is planned. As a result, irreparable damage to the ecology and fauna of the region is caused.

Moreover, the local population is forced to leave their habitable places in search of a peaceful life. On the border with neighboring Kenya, a large concentration of refugees has formed, who are fleeing the persecution of gangs supporting transnational companies.

The Kenyan authorities say they cannot accept such a large number of refugees, given the equally difficult situation in their own country. In this regard, the Kenyan Foreign Ministry proposed to immediately contact the African Council to resolve the incident. However, multinational companies, backed by the criminal structures of Southeast Africa, do not heed the demands of the African Council and continue to rampage.

Recently, the situation is heating up every day. The repeated efforts of the African Council have not yielded the expected results. In this regard, the heads of state of the region have collectively turned to the UN Secretary General for urgent action. In the coming days, an emergency meeting of the UN Security Council will be convened, which will consider only one issue - the conflict in southeast Africa.

According to observers, only the immediate sending of blue helmets can lead to the stabilization of the situation in the region. In addition, the Kenyan authorities say they need the help of the Red Cross and Doctors Without Borders, as well as humanitarian aid, in order to somehow hold out for the refugees until the conflict situation is resolved.

It is also noted that a UN peace plan of action will be required to return refugees to their homes and restore a peaceful life. 
1. Conference Interpreters Face Tumultuous EU Measures. Association of Conference Interpreters, Auxiliary Conference Interpreters, European Commission, European Parliament, European Union. MultiLingualStaff on October 12, 2020.

2. Materials XVI International Scientific Practical Conference. Check out the research - 15 - 22 February 2020 Volume 11 Methodology for teaching foreigners a language. A.Kh. Aripova. Kh.Sh. Khojaeva

3. Methods, aspects and components of teaching the uzbek (Russian) language as a foreign language on the experience of foreign students. Journal of Critical Reviews ISSN- 2394-5125 Vol 7, Issue 4, 2020 A.Aripova, Kh.Khodjayeva, N.Yuldasheva

4. Academicia an international multidisciplinary research journal. (Double Blind Refereed \& Peer Reviewed Journal) The ideal appearance of a modern teacher. A.Aripova, Kh.Khodjayeva

5. https://aiic.org/site/EU 


\title{
STATE AND LAW
}

\section{ISSUES OF THE CONCEPT AND CLASSIFICATION OF CRIMES AGAINST THE FAMILY IN THE CRIMINAL CODE OF THE REPUBLIC OF UZBEKISTAN}

\author{
Ibrokhimova Zulxumor Solih qizi, \\ Base doctoral student TSLU
} zulxumor2021@mail.ru

\begin{abstract}
Annotation: This article reveals an analysis of the legal framework for criminal liability for committing intentional acts against the interests of the family, considers the concept of crimes against the family, the classification of crimes of this category, based on various criteria. Based on the current criminal legislation of the Republic of Uzbekistan, the author classified groups of crimes against the family.
\end{abstract}

Key words: family, child, children, minor, parents, foster family, patronage, family interests, development, criminal responsibility, crime

Crimes against family and minors include socially dangerous acts provided for by the norms of Chapter V of the Criminal Code of the Republic of Uzbekistan, responsibility for which is established on the basis of the provisions of the Universal Declaration of Human Rights of 1948, the International Covenant on Civil and Political Rights of 1966, as well as the UN Convention on Rights child of 1989. According to the Universal Declaration of Human Rights (paragraph 3 of Art. 16) and the International Covenant on Civil and Political Rights (paragraph 1 of Art. 23), the family is a natural and fundamental unit of society and has the right to protection from society and the state. A child, due to his physical and mental immaturity, needs special protection and care, including adequate legal protection, both before and after birth. The Convention on the Rights of the Child names the right to life, the right to health, to be cared for by parents, the right to protection from any form of aggression, exploitation and negative information as the most important rights of the child.

At the same time, the object of this category of crimes is social relations that ensure normal material conditions for the existence of the institution of the family, as well as health, normal physical development of minors or disabled persons, who in relation to the perpetrator, as a rule, are children (relatives or adopted) $[11,123]$.

Ensuring and protecting these rights of the child is the responsibility of any state. In article 63 of the Constitution of the Republic of Uzbekistan, the family is the basic unit of society and has the right to protect society and the state. A similar rule is provided for by Art. 4 of the Family Code of the Republic of Uzbekistan. This general provision is concretized in a number of laws and other normative legal acts. The state recognizes childhood as an important stage in human life and proceeds from the principles of the priority of preparing children for a full life in society, developing socially significant and creative activity in them, fostering high moral qualities, patriotism and citizenship in them - is declared in Article 4 of the Law of January 7, 2008. № ZRU-139 «On guarantees of the rights of the child.» In accordance with paragraph 2 of Art. 4 of this Law, one of the main directions of state policy for the protection of the rights of the child is to ensure the rights, freedoms and legitimate interests of the child, to protect the life and health of the child, to prevent discrimination of the child, to protect the honor and dignity of the child.

The identity of the child is formed in the family, therefore the issue of protecting the identity of a minor is closely related to the issue of protecting family relations. The obligatory elements of the complex of measures for the protection and protection of the family, childhood, the rights of parents and children include the criminalization of acts that infringe on the rights and legitimate interests of minors, generally accepted family values, on the rights and interests of family members. This criminalization was carried out in 1994 with the adoption of the Criminal Code. The singling out of an independent chapter "Crimes against the family and minors" in Section 1 of the Criminal Code "Crimes against the Person" should be considered as an achievement of the current criminal law, a continuation of the traditions of criminal law.

Crimes against the family are those provided for by Art. 122-126 Chapter 5 of the Criminal Code 
deliberate socially dangerous acts (actions or inaction) that infringe on the interests of the family and may harm the health, physical, mental, moral, intellectual development of minors.

At the same time, in legal science there is no single approach to the definition of the concept of «family». For example, the Family Code does not contain a legal definition of the term "family". In the theory of civil and family law, the family is understood as a circle of persons united by mutual personal non-property and property rights and obligations arising from marriage, kinship or the adoption of children for upbringing in the forms provided by law (guardianship, guardianship, adoption, foster family, etc.) [3, 352].

A family is a specific set (community, group) of people, according to the general rule of relatives, based on marriage, kinship and property, living together and maintaining a common household, forming a natural environment for the well-being of its members, raising children, mutual assistance, procreation.

Distinguish between the concept of a family in the sociological and legal sense. In the sociological sense, a family is an association of persons based on marriage or kinship, linked by personal nonproperty and property relations, mutual support and raising children.

In the legal sense, a family is a circle of persons bound by rights and obligations arising from marriage, kinship, adoption or another form of fostering children. The family in the sociological sense can break up in the event of the termination of the actual marriage relationship, but in the legal sense it can remain (for example, the spouses do not actually live together, but their legal rights and obligations exist) [1].

The family, as a translator of fundamental values, performs the most important functions of reproduction and socialization of new generations, including those aimed at preserving, developing and transmitting to future generations the values and traditions of society, realizing the educational potential, meeting people's needs for psychological comfort and emotional support, a sense of security, feeling the value and significance of one's «I», creating conditions for the development of the personality of all family members, meeting the needs for joint leisure activities, organizing joint housekeeping, meeting a person's need for communication with loved ones, meeting the individual need for fatherhood or motherhood, contacts with children, their upbringing, organization of activities for the financial support of the family $[10,40]$.

The norms of Chapter 5 of the Criminal Code protect the most important interests of the family as a social institution. Interests related to the organization of activities for the financial support of the family - the norms of Art. 122-123 of the Criminal Code, interests related to the birth, upbringing of children, satisfaction of the individual need for paternity or motherhood, contacts with children, are protected by the provisions of Art. 124, 125 of the Criminal Code. In Chapter 5 of the Criminal Code, the legislator uses the following concepts: a minor (Articles 122, 127 of the Criminal Code), a child (Article 124 of the Criminal Code), children (Article 125 of the Criminal Code), marriageable age (Article 1251 of the Criminal Code). It should be noted that the concept of «child» is a multifaceted category both in the general scientific and legal sense. This term is used in the normative acts of various branches of law, and its content varies depending on the purpose and objectives of the branch of law, within which the influence on the corresponding relations is carried out $[10,43]$. In the Law «On guarantees of the rights of the child» (paragraph 1 of article 3), a child is understood as a person who has not reached the age of eighteen years (majority).

According to Art. 1 of the 1989 UN Convention on the Rights of the Child, a child is every human being up to the age of eighteen, if, according to the law applicable to this child, he does not reach the age of majority earlier. We believe that for the purposes of Chapter 5 of the Criminal Code, the definition of a child given in the Law on Guarantees of the Rights of the Child should be used - a person under the age of eighteen (majority). We also believe that the concepts of «minor», «child», «children» within the framework of the analyzed chapter of the Criminal Code have the same content and they should be understood as persons under the age of eighteen years (majority).

The interests of the child are one of the most important categories, to which special attention is paid in family law. Thus, A. Yu. Sologub sees the interests of the child in creating the conditions necessary for his maintenance and successful development [8,142]. A.M. Nechaeva believes that it is "development" that constitutes the basis of the concept of "interests of the child". Assessment of the child's interests from the point of view of his development (moral, spiritual, physical) is the first step in determining his true interests as a developing personality [4, 62]. It seems possible to agree that the basis of the interests of a child (minor) is his development (physical, mental, moral, intellectual, 
social). The physical development of a person is one of the important indicators of his health and wellbeing. Physical development of a person is a complex of functional and morphological properties of an organism, which determines its physical capacity. This complex concept includes factors such as health, physical development, body weight, level of aerobic and anaerobic power, strength, muscle endurance, coordination of movements, etc. It is known that in addition to the absence or presence of a disease, health is mediated by harmonious development, the level of basic physiological indicators $[6,4]$.

Mental development is associated with the development under the influence of training and education of mental processes and mental properties of the individual. Mental processes proceed according to certain stages corresponding to a certain age period. Moral development is a process of consistent accumulation of qualitative and quantitative indicators of changes in spiritual values, ensuring the entry of a person into the socio-cultural environment on the basis of his morally oriented, creative life and successful self-realization in the state and society. Intellectual development means the formation of the ability to master and use various types of thinking. The content side of intellectual development includes a certain amount of basic scientific knowledge about the world and the ability of a philosophical, concrete historical assessment of reality [11, 17].

The interests of the family, connected with their normal physical, mental, moral, intellectual, development of children, are to the greatest extent protected by Articles 122, 1251 of the Criminal Code. A separate category, in our opinion, is the interests of minors in the field of family relations, in particular, relations aimed at satisfying the need of a minor to communicate with loved ones (protected by Article 124 of the Criminal Code), relations for raising children (protected by Article 125 of the Criminal Code).

The development process takes place through the implementation of the education process. In accordance with the Action Strategy of the Republic of Uzbekistan, approved by the Decree of the President of the Republic of Uzbekistan No.UP-4947 dated February 7, 2017, the priority task in the field of improving state youth policy is the upbringing of physically healthy, spiritually and intellectually developed, independently thinking, devoted to the Motherland, young people with strong life views, increasing its social activity in the process of deepening democratic reforms and the development of civil society.

The family plays a decisive role in the development of a highly moral personality. The first substantial component of the concept of «family education» is associated with the child and his personality. In accordance with Part 1 of Art. 65 of the Family Code, every child has the right to live and be raised in a family, the right to know his parents, the right to their care, the right to live together with them, except in cases where this is contrary to his interests.

The second component of family education is the educational impact on the child. The Family Code contains parental rights and responsibilities in this area. The third substantial component of family education is that the educational impact on the personality of the child is carried out in all directions, including the physical, moral, intellectual, social component. This component is determined through a list of parental rights and responsibilities [2, 672]. The question of whether there should be an exhaustive list of the rights and obligations of parents in the implementation of the upbringing process is debatable. According to some authors, the relationship between parents and children should be maximally clothed in a legal form in order to avoid violating the rights and interests of both the child and his parents $[9,11]$. Other authors believe that the law should not contain detailed constructs of parental rights, since each parent brings up a child in his own way. According to some authors, the legislator, without interfering in this purely individual process, only sets the limits for the exercise of parental rights and responsibilities [7,3]. We believe it is possible to agree with this position.

In accordance with Art. 75 of the Family Code, parental rights cannot be exercised in contradiction with the interests of children. Safeguarding the interests of children should be the primary concern of their parents. When exercising parental rights, parents do not have the right to harm the physical and mental health of children, their moral development. Methods for raising children should be free from derogatory, cruel, rude, degrading treatment, abuse or exploitation of children. The rights of minors in case of evasion of maintenance, that is, failure to pay for more than two months in total of the funds subject to recovery by a court decision or a court order for the maintenance of a minor, are protected by Art. 122 of the Criminal Code. Thus, the interests of minors, protected by the provisions of Chapter 5 of the Criminal Code, can be divided into two types: interests related to the physical, mental, moral, intellectual, social development of minors; interests of minors in the field of family

January-February, 2021 
relations.

As already noted, in Chapter 5 of Criminal Code 5, for the first time, the consolidation of norms on crimes was carried out, the main object of which is social relations that ensure the normal development and education of minors, as well as the correct functioning of the family that meets the needs of the individual and society. In science, various classifications of this group of crimes have been proposed. The division into two subgroups most often occurs in the scientific literature: crimes against the family and crimes against minors [5, 286].

The following classification is proposed:

1. Crimes encroaching on the family structure, the interests of the family: substitution of a child (art. 124 of the Criminal Code); divulging the secrets of adoption or adoption (Article 125 of the Criminal Code); evasion from the maintenance of minors or disabled persons (Article 122 of the Criminal Code).

Crimes against family and minors can be subdivided in another way: 1) into crimes aimed at obstructing the moral, moral, mental, physical development of minors (see Articles 122, 124, 125 of the Criminal Code); 2) crimes that undermine kinship and family foundations that have developed in society (see Articles 123, 1251, 126 of the Criminal Code).

Depending on the intensity of the negative impact on a particular object, P.A. Filippov classifies these crimes into two groups: 1) crimes that infringe on the interests of minors to a greater extent; 2) crimes that infringe on the interests of the family to a greater extent $[11,17]$.

In our opinion, the crimes provided for in Chapter 5 of the Criminal Code can be classified as follows:

1) crimes that infringe on the normal physical, mental, moral, intellectual development of minors (Articles 122, 124, 125 of the Criminal Code);

2) crimes infringing on the interests of minors in the field of family relations (Article 1251 of the Criminal Code); 3) crimes that infringe on the interests of the family as a whole (Articles 123, 126 of the Criminal Code).

We propose this classification with the proviso that such a division is conditional, since when committing crimes provided for in Chapter 5 of the Criminal Code, harm is caused simultaneously to the interests of the minor and the interests of the family.

\section{References}

1.Grishaev S. P. Article-by-article commentary to the Family Code of the Russian Federation. 2nd ed. revised and add. Prepared for the «Consultant Plus» system, 2017. Access from the reference legal system «Consultant Plus». // Гришаев С. П. Постатейный комментарий к Семейному кодексу Российской Федерации. 2-е изд. перераб. и доп. Подготовлен для системы «Консультант Плюс», 2017. Доступ из справ.-правовой системы «Консультант Плюс».

2.Komissarova E.G., Krasnova T.V. The right of the child to family education: a regulatory aspect // Bulletin of Perm University. Legal sciences. 2019. No. 4. Р. 672-697. // Комиссарова Е. Г., Краснова Т. В. Право ребенка на семейное воспитание: регулятивный аспект // Вестник Пермского университета. Юридические науки. 2019. № 4. С. 672-697.

3.Commentary on the Family Code of the Russian Federation: (educational and practical): (itemized) / O. Alekseeva, L. V. Zayets, L. M. Zvyagintseva [and others]; ed. S. A. Stepanova. M., 2015.352 p. Access from the sprav.-legal system «ConsultantPlus». // Комментарий к Семейному кодексу Российской Федерации: (учебно-практический) : (постатейный) / О. Г. Алексеева, Л. В. Заец, Л. М. Звягинцева [и др.] ; под ред. С. А. Степанова. М., 2015. 352 с. Доступ из справ.-правовой системы «КонсультантПлюс».

4.Nechaeva A.M. Protecting the interests of a child in a large family // Laws of Russia: experience, analysis, practice. 2012. o. 6. Р. 62. // Нечаева А. М. Защита интересов ребенка в многодетной семье // Законы России: опыт, анализ, практика. 2012. № 6. С. 62.

5.Paliy VV Object of crimes against family and minors: controversial issues // Actual problems of Russian law. 2010. №. 3.P. 286. // Палий В. В. Объект преступлений против семьи и несовершеннолетних: спорные вопросы // Актуальные проблемы российского права. 2010. № 3. С. 286.

6.Developmental psychology and developmental psychology: textbook. and a workshop for universities / OM Anisimova, VE Vasilenko, LA Golovey [and others]; under total. ed. L.A. Golovey. 2nd ed., Rev. M., 2020.S. 4. (Higher education). // Психология развития и возрастная психология: учеб. и практикум для вузов / О. М. Анисимова, В. Е. Василенко, Л. А. Головей [и др.] ; под 
общ. ред. Л. А. Головей. 2-е изд., испр. М., 2020. С. 4. (Высшее образование).

7.Smirnovskaya SI Restriction of parental rights under the family legislation of the Russian Federation: specialty 12.00.03 "Civil law; business law; family law; international private law «: dis. ... Cand. jurid. Sciences / Institute of State and Law of the Russian Academy of Sciences. M., 2007.S. 3. // Смирновская С. И. Ограничение родительских прав по семейному законодательству Российской Федерации : специальность 12.00 .03 «Гражданское право; предпринимательское право; семейное право; международное частное право» : дис. ... канд. юрид. наук / Ин-т государства и права РАН. М., 2007. С. 3.

8.Sologub A. Yu. Category «legitimate interest» as an element of the child's legal status // Questions of modern jurisprudence. 2013. No. 29, p. 142. // Сологуб А. Ю. Категория «законный интерес» как элемент правового статуса ребенка // Вопросы современной юриспруденции. 2013. № 29. C. 142 .

9.Staroseltseva MM On the principles of the exercise of parental rights // Modern law. 2008. No. 11.P. 36. // 9. Старосельцева М. М. О принципах осуществления родительских прав // Современное право. 2008. № 11. С. 36.

10.Usacheva EA The concept of «child» in the categorical apparatus of family law regulation // Laws of Russia: experience, analysis, practice. 2016. No. 8. Р. 40-43. // Усачева Е. А. Понятие «ребенок» в категориальном аппарате семейноправового регулирования // Законы России: опыт, анализ, практика. 2016. № 8. С. 40-43.

11.Criminal law of the Republic of Uzbekistan. Special part: Textbook. for universities / M. Kh. Rustambaev; Ministry of Justice Resp. Uzbekistan, Tashkent. state jurid. in-t. - Tashkent: World of Economics and Law, 2002. - P.123. // Уголовное право Республики Узбекистан. Особенная часть: Учеб. для вузов / М. Х. Рустамбаев; М-во юстиции Респ. Узбекистан, Ташкент. гос. юрид. инт. - Ташкент : Мир экономики и права, 2002. - С.123.

12.Filippov PA Lectures on crimes against family and minors: textbook. allowance. M., 2019, p. 17 // Филиппов П. А. Лекции о преступлениях против семьи и несовершеннолетних : учеб. пособие. М., 2019. С. 17. 


\title{
THEORETICAL AND METHODOLOGICAL BASIS OF STUDYING THE CONTENT OF POLITICAL CONSCIOUSNESS
}

\author{
Kuyliev Bobur Tulkinovich \\ National University of Uzbekistan named after Mirzo Ulugbek \\ Basic doctoral student of the Department of Civil Society and \\ Legal Education, Faculty of Social Sciences \\ Assistant of the Department of Philosophy, ToshPTI
}

\begin{abstract}
Annotation. In this article, the category of political consciousness is analyzed from a conceptual point of view, and the elements that make up its categorical structure are considered separately and in a dialectical unity. At the same time, special emphasis is given on the question of the balance of its psychological and ideological levels. In addition, concepts such as political identity, political institutions and political mentality, which are the components of the category of political consciousness, are analyzed from a comparative point of view. Emphasis is also placed on the relationship between individual and mass forms of political consciousness.

Keywords: Political consciousness, political relations, political institutions, political behavior, political mentality, political identity, political values, political interest, political knowledge, political processes.
\end{abstract}

Public (mass) political consciousness can be described as a subjective expression of political processes. The category of public political consciousness is thoroughly studied by researchers such as A.Avtorkhanov, V.P.Andreev, S.S.Andreev, G.A.Belov, K.S.Gadjiev, G.T.Deligenskiy, Yu.V.Irkhin, M.V.Ilin, P.F.Draker, V.P.Makarenko, A.Yu.Shutov, V.Yu.Shpak, A.I.Djenusov, K.S.Gadjiev, N.N.Bogomolova, and L.Ya.Gozman. According to them, the concept consists of ideological and psychological levels.

Politics is reflected, at the ideological level of public political consciousness, as an abstract idea or a specific theoretical model, in other words, as an ideological doctrine. Politics manifests itself, at the psychological level, in the form of psychological attitudes, values, emotions, and moods.

Political consciousness is not the product of individual experience only. It can be described as a set of mental phenomena that are reflected in the perception of the individual subject of political processes. Actually, there are a number of factors, which play an important role in its formation, such as social environment, political relations, and political conjuncture. In addition, this concept helps to describe the individual subject of the political process through the internal processes occurring in the mind of the individual. The concept of political consciousness also helps to describe the complex subjects of political processes. For instance, it would be wrong to state the firm idea that this or that political consciousness corresponds to a particular political system. In this case, using the concept of political culture would be appropriate. In this sense, it is clear that the concept of "political consciousness" refers to a relatively subjective phenomenon when taken in relation to the category of "political culture".

It should be particularly noted that the concept of political consciousness includes not only the values, psychological institutions, but also the psychological mechanisms of their processing, in short, the process of seeking a personal position. Given the serious impact of the environment in this regard, it should be noted that this phenomenon has an individual character. Therefore, it is controversial to apply the concept of "political consciousness" to political actors in group or other complex subjects.

Political consciousness is closely linked with political behavior and is considered to be one of the stages in its formation. In this sense, political consciousness as an element of political behavior, which fills it with meaning, reveals political relations among the subjects of political processes ${ }^{1}$. The same consideration was developed in the works of major researchers such as G.Blumer, E.V.Veritneva, V.K.Vilyunas, and M.V. Demin. Accordingly, political consciousness is defined as an internal political behavior that affects a person's external behavior, more specifically, his activity and level of activeness. In the analysis of political behavior I.M.Slepenkov, Y.P.Averin, A.K.Markova, and V. Odaynik pay special attention to the concept of political activism. During the process of this analysis E.Vyatr highlights the concept of political relations. Hence, the following types of political behavior can be distinguished: individual political influence (E.V.Veritneva), public political influence

\footnotetext{
Авторханов А. Технология власти. М., 1992. С-34
} 
(M.M.Nazarov), spontaneous political behavior (A.P.Nazaretyan) and provocative political influence (M.S.Haveshi).

Based on the analysis of the above considerations, it is possible to distinguish the components of political consciousness that are cognitively oriented and characterized by motivational groups. Interest in political knowledge, political events, and political professions are all considered to be the components of the cognitive group of political consciousness ${ }^{2}$. Needs, values, emotions, and psychological attitudes can be listed as elements of a motivational group. Obviously, is a bit complicated to distinguish any element of political consciousness in its purest form, as well as to emphasize that it belongs to a knowledge-oriented or motivational group. The elements belonging to both groups are linked with each other, and permanently complement each other ${ }^{3}$. Thus, the political profession is formed under the influence of certain emotions, needs and serves as the basis of any political institution.

\section{Reference books}

1. Авторханов А. Технология власти. М., 1992.

2. Андреев В.П. Проблемы политического поведения масс и современная Россия. Новосибирск, изд-во НГУ, 1994.

3. Андреев С.С. Политические системы и политическая организация общества. // Соц. политич. науки, 1992, № 1.

4. Гаджиев К.С. Политическая философия - М.,1999.

5. Делигенский Г.Т. Социально-политическая психология. М., 1996.

6. Ирхин Ю.В. Психология и политика - М., 1993.

\footnotetext{
2 Андреев В.П. Проблемы политического поведения масс и современная Россия. Новосибирск, изд-во НГУ, 1994. С-102

3 Андреев С.С. Политические системы и политическая организация общества. // Соц. - политич. науки, 1992 , № 1. C-97
} 


\section{LINGUOCULTURAL ASPECTS OF THE STUDY OF WORD MEANING}

G'ofurova Mavluda Botirjon qizi

Kokand State Pedagogical Institute. Faculty of Filology

The conceptual worldview is an essential condition for the life activities of a person who is biosocial. Throughout his conscious life, man repeatedly refers to, uses, accepts, contributes to, and perfects the categories of conceptual worldviews. (See Ufimieva N.V. 1996, Yakovenko E.B. 1999, Chomsky N.1968).

The formation of a linguoculturological background or worldview is a long historical process that has come a long way from the primitive archaic stage to the modern scientific stage. In the distant past, our ancestors were far from the current scientific theory of the world and its creation. The mythological worldview of different peoples is an example of this.

M.Khalikova divides the essence of worldviews formed on the basis of linguocultural knowledge into several types;

- worldview formed through the personal experience of each person;

- Linguistic worldview formed within a certain language;

- a conceptual worldview that is unique to all individuals.

The national character of the worldview, as we have noted above, is due to its limitation within a particular language. The metaphors, stereotypes, and standards that permeate every linguocultural community lead to a feature that is unique to only one language. For example, to know well, the meaning is expressed in Uzbek, Czech and French as «to know like five paws», «to know like one's own pocket», «to know like one's own boots».

Thus, there is a complex and infinitely ongoing relationship between the lingvoculturological background, the model, and the conceptual picture, i.e., the understanding of the world within a particular language and the general worldview.

In order to unite the national with specific, subjectively meaningful universal concepts, it is necessary to go through intermediate stages, that is, the need to transform the «internal model» into a «universal model» requires some kind of intellectual transformation phase. According to L. Weiserberg, linguistic meaning plays the role of an intermediate world. (See Ashurova D.U.2003, Boboxonova L.G.1995, Boduen de Kurtene 1993, Vejbitskaya A.1997).

According to V.A. Zvegintsev, "The process of cognition is the activity of this thought, which is aimed at creating an internal model of the world given by experience in the mind. At this point, language objectifies this model in the process of communication activity, making it the basis of communication. Semantic meaning arises as a result of the act of thinking. Through it, man communicates this or that with his inner world, and through language, he communicates with other people's inner models. In this way a linguistic model of the world observed in this or that language emerges.

Where there is no historical or factual material, some researchers claim that «man first linguistically systematized the experience he gained by observing and seeing beings,» and they try to prove this idea by the mythological material that exists in world languages and the material of underdeveloped languages.

The model of scientific perception, which is closely connected with the knowledge of the objective being, consists of a transitional stage, followed by the artistic expression of the being, which indicates that the language is fully formed. References to history should serve as one of the arguments used to confirm, reinforce the general idea in these cases. (See Vinogradov V.V. 2003, Wolf E.M. 2002, Vorobev V.V. 1996, Gak V.G. 1977, Gaffarova G. 1997)

In this case, language must manifest itself as the creator of its own lingvoculturological model, and as a result it must become an independent force of "linguistic cognition". This is inconsistent with the assertion that the original judgment is the material form of consciousness. The subjective nature of language becomes the decisive force of cognition, and its structure turns out to be immanent, inherently hereditary, innate. It is aimed at creating and transmitting information, thoughts, knowledge about an objective being. The language system itself contains this linguistic commonality that arises in the process of knowing existence.

The system of concepts expressed in language expresses such a complex relationship of concepts that their complex use allows to convey the content of human thought in different ways, that is, using simple and descriptive definitions. This is the peculiarity of language, that is, language is a tool for 
the formation of thought, language can be not only a means of storing knowledge, but also a way of expressing it with the dynamics of its development. From a semantic point of view, different national languages are different variants of the nominal structure of «universal concepts», a potentially unique universal culture - a whole of civilization. (see; Guhman M.M. 1985, Demkov V.Z. 1994, Djusupov N.2006, Karaulov Y.1972)

The system of language, which manifests itself as a system of signs of self-regulation, dual character, and which serves to form and convey thought in its complex application, cannot be regarded as a «linguistic image of being.» Knowledge creates the image of the world, not language.

A more rigorous approach to this, the presented image can only be created ideally using full text, i.e. universal language. Knowledge of the conceptual systems of national languages cannot be simplified in terms of the "accuracy of the results. These systems, on the other hand, are considered to be different variants of a single universal human language, and their content is historically flawed. (See; Karasik V.I. 2001, Kibrik A.A. 1994, Kubryakova E.S. 1994, Lakof Dj. 1987, Lebedeva L.A. 1999, Lukyanova N.A 1986)

In this regard, the solution of lingvoculturological problems cannot be said to have been methodologically correct by the attempts to compare separate language event events isolated from different languages (which was especially often done by B. Warf and his followers). Here, basically, two serious mistakes are made, which are not difficult to perceive not only by an expert who has studied the problem in depth, but also by an ordinary reader. These are:

b) The first mistake is to try to compare the facts of the studied language not with the system of concepts, but directly with the existing things in the material being.

c) The second error is the analysis of this or that unit or form in the language outside the language system, in other words, the analysis does not involve the scope of the complex mechanism of language. aside.

The first mistake leads the authors to the conclusion that "there is a lingvoculturological model of the world". In fact, the linguist had to show the peculiarities of concrete forms in a general language system capable of expressing any concept.

The second error distorts the essence of language, denying that language can be analyzed as a whole system, in which only parts of the language are systematically analyzed and unreasonably compared to other languages. and the Uzbeks have not been able to fit this concept into their minds, or the Uzbek perception and thinking have never encountered this thing before.

When words in two or more languages are compared in some way, and when there is a mismatch of meanings, linguists come to the «universal» conclusion that «the conceptual apparatus of peoples who speak different languages is different.»»

It is incorrect to equate the additional national subjective information brought in by the lexical model of language with the specific information brought by the language into the linguistic landscape of the world according to the Sepir-Wharf hypothesis. because the lexical model of language has been associated not only with the lexical but also with the grammatical aspect within this hypothesis. Therefore, the information expressed by grammatical means cannot be excluded from the information entered by the lexical model of the language.

Many researchers repeatedly refer to linguoculturology and the Sepir-Wharf hypothesis. But they can find neither theoretical nor experimental evidence to serve his defense. Well-known scientist E. Lenneberg, concluding the discussion of the experimental study of the Sepir-Wharf hypothesis, was forced to conclude that "there is very little evidence of a violent judgment on the knowledge of the word".

The results of experiments conducted in the field, as well as concrete practical research in this area, show that the Sepir-Wharf hypothesis does not correspond to reality in its classical form.

National identity should be sought not in the linguistic description of the world, but in the specificity of human cognitive activity, which is closely linked to various geographical, historical, productionrelated, and many other factors. (See: Tukhtasinov I. 2004, Umarov E. 1995, Urison E.V. 2003, Fedoryuk A.V.2001, Hakimova G. 2008, Hammatova A.Sh. 1999, Kharitonchik Z.A.1986, Cheyf U.L. .1975, Shomaqsudov A. 1983)

It should be noted that the logical-philosophical analysis of the problem of national identity of language and its lingvoculturological model in relation to the human worldview remains rather speculative and does not help to draw any clear conclusions from the theoretical study of the problem of national language-folk thinking. But psycholinguistic analysis of speech confirms the specificity 
of language as an isomorphic process of consciousness. But it does not prove that language plays a dictatorial role in thinking.

In such cases, the various hypotheses that often arise in the process of translating from one language to another, as well as the loss of the «psyche» of the language in translation, are often cited as evidence of the above hypothesis.

All of them are methodologically incorrect, because the method of proof cannot be applied to language, and because the information given at the entrance and at the exit belongs to different layers and scales, it contradicts the basic logical rules for the correctness of judgments. For example, the fact that there is an article in German does not mean that Germans accept objects according to some gender-related features.

The Uzbek and Russian words «kol» are pronounced with the English words «hand», «arm», the Uzbek words «kaptar» and «musicha» are given with the same German word «taube». may not lead to the conclusion that the bird cannot be separated from each other. Because in practice, the Germans do the same thing as the Uzbeks do the difference between pigeons and music. (See: Maslova V.A.2004, Muslenko V.P. 1989, Mirtojiev M.2008, Matyakubov J.I.1996, Ne'matov X.1995, Oparina E.O.1999, Rodionova S.E. 1992, Radchenko G .I. 2007)

The fact that the word «know» in Uzbek is given with the German verbs «wissen» and «kennen» does not mean that Germans know more than Uzbeks, or understand different types of knowledge. Which of the following determines the nature of the relationship between language and thinking? Language or thinking? In answering the question, most people answer "thinking". But some answer "language". If the ratio is 90/10, then Sepir and his followers make up 10\%. However, minorities do not always turn out to be wrong.

In our opinion, both language and thinking have their own logic, and this logic distinguishes languages from each other. The thinking among nations is the same, its logic is the same. The language of the peoples is different and the logic of the language in them is also different. The word logic defines selection. Logic is defined by thinking. So, thinking is primary.

\section{References}

1. M.Khalikova National mentality and its interrelation with the picture of language - «Language and literature education» -2002, No. 6, pages 23-27

2. В.А. Звигенцев Язык и лингвистическая теория стр.174

3. E.Lenneberg, J. Roberts. The Language of Experience, Bloomington, 1996, p.354

4. Буй Динью Ми. Взаимоотношенние языка. Культуры и национальный специфики психики в познавательной деятельности, Автореф.Канд.Дисс.1973, стр 25 


\title{
STUDY OF THE FREQUENCY OF DEVELOPMENT OF SYNCHRONOUS AND METACHRONOUS TUMORS IN PATIENTS WITH MALIGNANT NEOPLASMS OF THE FEMALE REPRODUCTIVE SYSTEM
}

\author{
Izrailbekova Kamila Shavkatovna \\ Republican Specialized Scientific-Practical Center of Oncology \\ and Radiology under the Ministry of Health of the Republic of Uzbekistan \\ the city of Tashkent
}

Relevance of the Topic. Although there have been a great deal of scientific and practical research on multiple primary malignant tumors (MPMT) with damage to the organs of the female reproductive system, this topic remains not completely researched. At the same time, the literature data on the quantitative ratio of synchronous and metachronous tumors in this category of patients has great variability, whereas the number of metachronous tumors is higher in most studies.

The Aim of the Work is to study the frequency of development of synchronous and metachronous tumors in patients with PMMT of the female reproductive system.

Materials of the Work. 80 patients were examined and treated in the chemotherapy department of the RSSPCOR MH UZ in the period from 2015-2020, among whom there were $38(34.5 \%)$ patients with breast cancer (BC), $22(20.0 \%)$ - ovarian cancer (OC), $12(10,9 \%)$ - uterine cancer (UC) and $8(7.3 \%)$ cervical cancer (CC). The age was from 23 to 79 , the average was $45.6 \pm 6.3$ years. Stages II-III of the disease predominated.

Methods of the Work. All patients were examined by standardized complex clinical-instrumental and laboratory diagnostic methods.

Results of the Work. Synchronous tumors were found in $12(31.6 \%)$ patients with BC, among them synchronous cancer of the second breast was found in $9(23.7 \%)$ of them, and $\mathrm{OC}-$ in $3(7.9 \%)$. In patients with initially detected $\mathrm{OC}, \mathrm{UC}$ and $\mathrm{CC}$, synchronous breast cancer was simultaneously detected - in $5(22.7 \%), 3(25.0 \%)$ and $2(25.0 \%)$ respectively. At the same time, metachronous cancer that developed within 6 months and over was detected in $26(68.4 \%)$ patients with BC, among them metachronous cancer of the second breast - in $14(36.8 \%), \mathrm{UC}-$ in $7(18,4 \%)$ and OC - in 5 $(13.2 \%)$ patients. In patients with OC and CC, metachronous BC was detected - in $17(77.3 \%)$ and 6 $(75.0 \%)$ respectively. And in patients with $\mathrm{UC}$, metachronous breast cancer was found - in $7(58.3 \%)$ and $\mathrm{OC}-$ in $2(16.7 \%)$.

Discussion of the Work. Present research shows the need for regular monitoring and timely diagnosis of this category of patients after completion of treatment, as well as the search for reliable clinical and laboratory risk factors for the development of metachronous tumors.

Results of the Work. Among patients with MPMT of the female reproductive system, metachronous tumors predominated - in $58(72.5 \%)$, synchronous tumors were found in $22(27.5 \%)$ patients. 


\section{APPLICATION OF ACT IN THE TEACHING OF ATOMIC PHYSICS}

$\mathrm{PhD}$ in pedagogical sciences, Jalolova Pokiza Muzaffarovna

Karshi branch of Tashkent University of Information Technologiyes named after Muhammad al-Khwarizmi

Tel: 998905552987

E-mail: pokiza-namdu@mail.ru

As can be seen from the figures, the geometric positions of the points which the electron can be recorded with the greatest probability correspond to the 1,2,3-Boron orbits. When the orbital quantum number is $1=1$ (R-state), three $\mathrm{m}=-1 ; \mathrm{m}=0 ; \mathrm{m}=1$ values of the magnetic quantum number correspond to three directions of the impulse momentum (Fig. 3 (a)). In this case, the value of the vector L will be:

$$
\mathrm{L}=\hbar \sqrt{\ell(\ell+1)}=\hbar \sqrt{2}
$$

\begin{tabular}{|c|c|c|c|c|}
\hline $\begin{array}{l}\text { Principal } \\
\text { quantum } \\
\text { number, } \mathrm{n}\end{array}$ & $\begin{array}{l}\text { Orbital } \\
\text { quantum } \\
\text { number, } l\end{array}$ & $\begin{array}{l}\text { Magnetic quantum } \\
\text { number, } l\end{array}$ & $\begin{array}{l}\text { Determination of } \\
\text { condition }\end{array}$ & $\begin{array}{l}\text { The } \\
\text { multiplication of variation (by } \\
\text { orbital impulse momentum) }\end{array}$ \\
\hline 1 & 0 & 0 & $1 \mathrm{~S}$ & 1 \\
\hline $\begin{array}{l}2 \\
2\end{array}$ & $\begin{array}{l}0 \\
1\end{array}$ & $\begin{array}{c}0 \\
0, \pm\end{array}$ & $\begin{array}{l}2 \mathrm{~S} \\
2 \mathrm{P}\end{array}$ & 4 \\
\hline $\begin{array}{l}3 \\
3 \\
3\end{array}$ & $\begin{array}{l}0 \\
1 \\
2\end{array}$ & $\begin{array}{c}0 \\
0, \pm\end{array}$ & $\begin{array}{l}3 \mathrm{~S} \\
3 \mathrm{P} \\
3 \mathrm{~d}\end{array}$ & 9 \\
\hline $\begin{array}{l}4 \\
4 \\
4 \\
4\end{array}$ & $\begin{array}{l}0 \\
1 \\
2 \\
3\end{array}$ & $\begin{array}{c}0 \\
0, \pm\end{array}$ & $\begin{array}{l}4 \mathrm{~S} \\
4 \mathrm{P} \\
4 \mathrm{~d} \\
4 \mathrm{f}\end{array}$ & 16 \\
\hline
\end{tabular}

The relationship between the orbital mechanical moment and the magnetic moment of electron is as follows:

$$
\begin{gathered}
\mathrm{P}_{\mathrm{m}}=\gamma \mathrm{L} \\
p_{m}=\frac{e}{2 m} \hbar \sqrt{\ell(\ell+1)}=\mu_{5} \sqrt{\ell(\ell+1)}
\end{gathered}
$$

Here, the measurement $\mu_{B}=\frac{e \hbar}{2 m}=0,927 \cdot 10^{-23} \frac{\mathrm{J}}{T l}$ is called Boron magneton.

The expression (9) above shows that the quantization of the magnetic moment $\mathrm{Pm}$ is derived the quantization of the mechanical moment L, as well.

The component of the orbital magnetic moment in the direction of the external magnetic field is defined as follows:

$$
P_{m z}=\nu_{z}=\frac{e}{2 m} \hbar m_{\ell}=\mu_{\mathrm{b}} m_{\ell}
$$




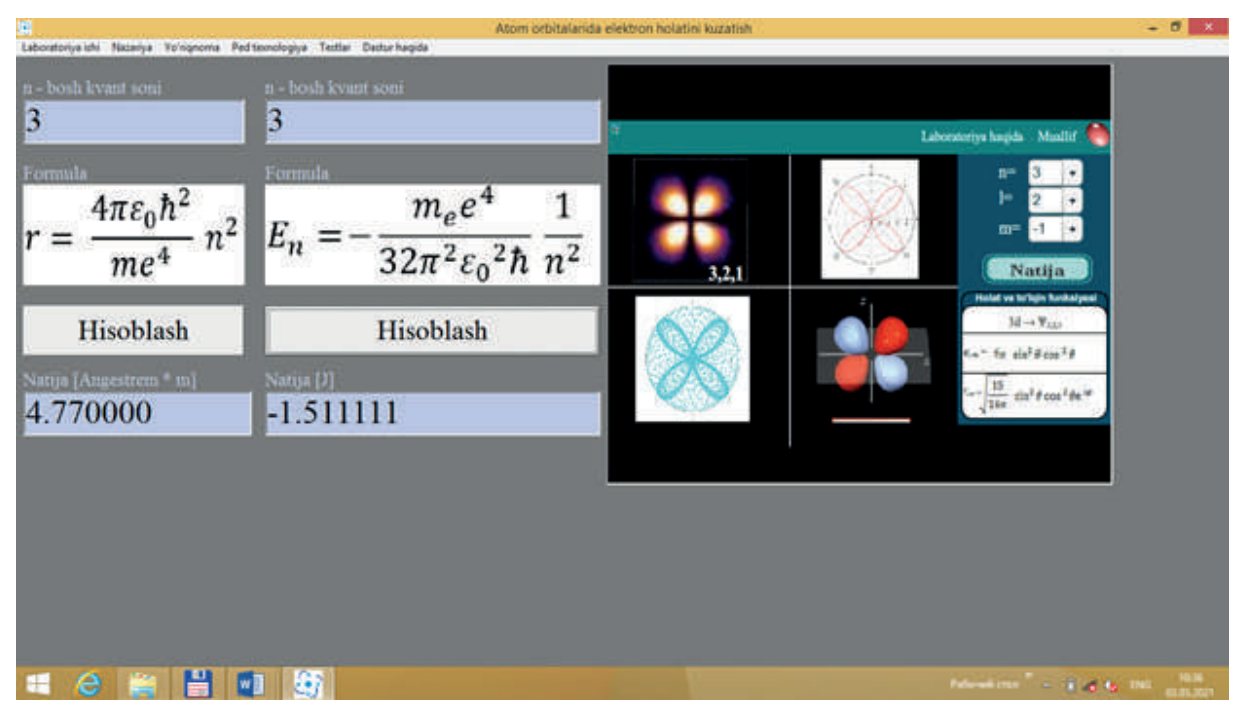

Figure 1. The main stable state of the hydrogen atom

Here $\mathrm{ml}$ is the magnetic quantum number. Since the mechanical moment and the magnetic moment are antiparallel, because their electron's charge is negative, namely, they are in opposite directions, and their position in space is quantized. For example, both moments are zero in the S-state $(l=0$, $\mathrm{m}=0$ ). The quantization of the mechanical and magnetic moments of electron in space had to be confirmed in practice. Such experiment was conducted in 1922 by German physicists Otto Stern and Walter Gerlach.

Quantum numbers $n$, land $\mathrm{m}_{l}$ give opportunity to us to fully describe the formation of releasing (absorption) spectrum of hydrogen atom which is derived from Boron theory.

\section{References:}

1.P.M.Jalolova. Methods of atomic physics classes organization based on e-learning technologies // European Journal of Research and Reflection in Educational Sciences №12 C.1547-1553 . Germany. 2020

2.P.M.Jalolova. Theoretical- methodological aspects of quantum physics section in the credit module system // Solid State Technology Volume: 63 Issue: 6 Publication . C.152-158 Year: 2020 (Scopus)

3.P.M.Jalolova. Методы использования информационных технологий в изучении физики. // Materialien von XVI International wissen schaftliche und praktische Konferenz Modernes 1wissenschaftliches Potenzial 28. Februar - März 2020, Volume 11.: Berlin. C.69-73.

4.П.М.Жалолова. Кредит-модул тизимида амалий машғулотларни ахборот технологиялари асосида ташкил қилиш методикаси.// НамДУ илмий ахборотномаси 2020 йил 5-сон Б.366-371

5.П.М.Жалолова. Масофавий таълим тизимида квант эффектларни дастурий ишланмалар асосида ўқитиш методикаси // НамДУ илмий ахборотномаси 2020 йил 8-сон Б.284-289

6.П.М.Жалолова. Кредит-модул тизимида талабаларни “физика” фанидан лаборатория экспериментларига виртуал ишланмалар асосида тайёрлаш методикаси // ЎзМУ. Физика фанининг ривожида истеъдодли ёшларнинг ўрни РИАК-XIII-2020 19 май. Б.331-334. 


\title{
CULTUROLOGY SCIENCE
}

\author{
УДК: 78.03(09)
}

\section{THE ROLE OF JIRAW IN KARAKALPAK NATIONAL MUSICAL ART}

Aytmuratov J. Aytmuratova Z.

Karakalpak state university, Nukus

\begin{abstract}
Annotation: Article based on historical sources, analyses the ways of formation of Karakalpak national musical arts,describes the mentors in school development, preservation and transmission from generation to generation of the unique and distinctive musical legacy of Karakalpaks zhyrau. Provides historical information about the global recognition of Karakalpak art narrators-bard.The article also provides scientific information about the formation and development of Karakalpak art of jiraw.
\end{abstract}

Key words: national music, jiraws, baqsis, kobyz, Karakalpak schools of baqsis, "Jeti Asyrim", «Mukhalles», dutarists, dastan (epic poem).

The article based on historical sources analyses the ways of formation of Karakalpak national musical art, highlights the role of the school of mentors in the development, preservation, and handing down of the unique and distinctive musical heritage of Karakalpak jiraws (The singers who sing perform epic poems by the accompaniment of the qobiz, Karakalpak national violin) and baqsis (the singers who perform epic poems by the accompaniment of the two - stringed musical instrument dutar) from generation to generation. The article also presents scientific information on the formation and development of Karakalpak art of baqsis which form the basis of Karakalpak music art, notes the role of the dutar player's ensemble «Mukhalles», as well as the role of modern young artists in the development of the art of jiraws and baqsis.

Indeed, now, we see how young people perform and listen to folk music with great love and interest.As history shows, at the origins of the national musical art were jiraws and baqsis, girzhek and balaman (pipe) players. One of the Karakalpak historian R. Kosbergenov wrote: "First the art of jiraws arose among them, later - the art of baqsis" $[1,66]$. Balaman and girzhek players accompanied the singing of baqsis. Performance of songs to the accompaniment of kobyz (a kind of Karakalpak national violin) has been known among Central Asian peoples since ancient times.Korkut Ata is known to have been the Father of Karakalpak School of jiraws. He lived in the lower reaches of the Syrdarya in the tenth century.According to popular legend, he was the first to produce kobyz and play on it $[2,35]$.

Relying on the information received from Esemurat jiraw and Kiyas jiraw, doctor of philological sciences, professor K. Aiymbetov stated that Korkut Ata and Divanu Buryk were at the origins of the art of jiraws $[3,79]$.Valuable sources on the activities of Korkut Ata were cited in the famous Oguz epos of Korkut Ata [4,166].

The development of the Karakalpak art of jiraws is associated with the name of Soppasly Sypyra jiraw. Details about him are given in the work of the candidate of art criticism T.Adambaeva [5,4]. Soppasly Sypyra jiraw lived in the $14^{\text {th }}$ century, as evidenced by the sources of folklore of Turkic peoples from the association of Nogais alternatively, Golden Horde State of Kazakhs, Bashkirs, Tatars, and Nogais. Works by Soppasly Sypyra jiraw, Korkut Ata, Asan Kaigy are common to most of the Turkic-speaking peoples.

First, the name of Soppasly Sypyra jiraw was introduced into scientific work by well known Kazakh scientist, ethnographer, and art critic Chokhan Valikhanov. He noted that Sypyra jiraw was one of the closest advisers of Tokhtamysh Khan and played many epics of the Nogayli period [6,5]. This fact is confirmed by the prominent Karakalpak scientist N. Davkaraev, who analyzed the history of the formation of the school of Karakalpak jiraws. According to him, there were two major schools of jiraws - Zhiyen jiraw's school and Soppasly Sypyra jiraws school [7,25].

With the help of the famous epos «Edige» well - known folklorist K.Aiymbetov proved that Soppasly Sypyra jiraw was a real historical person. In addition to him, he noted the works of such jiraws, 
folk tale narrators as Shankay jiraw (1814 - 1884), Zhiemurat jiraw (1836 - 1908), Nurabylla jiraw (1862 -1922), Erpolat jiraw (1861-1938), Kurbanbai jiraw (1876 -1958), Tore jiraw (1879-1944), Oteniyaz jiraw (1884-1954), Esemurat jiraw (1893-1980), and Kiyas jiraw (1903-1974) [8,79-91].

In the above-mentioned work, art critic T.Adambaeva noted high professionalism of jiraws folk tale narrators such as Khulamet, Arzymbet, Jumabai and Jaksilik [9,4-5].A significant contribution to Karakalpak art of narrators was made by Nurabulla jiraw Karazhan uly, who had his own school of performers. He had been called or nick named as "Bala jiraw." (Child bard) since his childhood.To learn the secrets of the art, he went to Bukhara. In Nurata, he learned for two years from Khalmurat jiraw. Here he learned to perform on the kobyz a number of folk eposes, termes (educational-didactic verses) and tolgaus (philosophical-lyric verses) - "Ilgal", "Tolgau", "Yar-Yar", "Jan-Jan", "Sybay", "Shapkyr", "Aituar", "Ormanbet", "Haujar". These facts were deeply researched by Professor K. Aiymbetov in his book "People's Wisdom" [10,83-84]. As the author notes, Nurabulla taught the Art of jiraws to 24 followers during his creative life, including his son Esemurat who became a famous folk tale narrators of the XX century.

One of the most famous folk tale narrators of the twentieth century was Esemurat jiraw, the son of the eminent Nurabylla jiraw.It is possible to trace the continuity of generations through his career. Esemurat followed his father from the age of 16, learned from him how to sing the folk eposes such as "Khoblan", "Alpamys", "Edige", "Maspatsha", "Bozuglan", "Ershora", "Sharyar" and folk songs tolgaus and termes[11,94].

As the research of the scientists from the sector of Art of Davkaraev Institute of Language and Literature of the Academy of Sciences of Uzbekistan shows, the number of well-known Karakalpak jiraws was more than a hundred.Detailed analysis is provided in the monografical work "The Life and Culture of Karakalpaks during the Period of Colonialism" by the historian R.Kosbergenov $[12 ; 67]$. He noted that such jiraws as Duisenbai, Paleke, Seydulla, Dauletbai, Shankay jiraw and Kabyl graduated from the narrators' school of Aituar jiraw in the $20^{\text {th }}$ century.In its turn Kazkhbai, Khalmurat and Erjan graduated from Kabyl jiraw's school.

Famous Karakalpak jiraw Kiyas jiraw Khayratdinov (1903 - 1974) learned the performance of more than ten eposes from Kabyl jiraw, and from Abdurasuly jiraw he learned the melodies of "Hayyar", "Ilgal”, "Kelte tolgau", "Ulli Ziban", "Kelte Ziban”, "Koz Aydin","Nama basy", "Sherbeyit", and "Darkar "[13;26]. He first served in Chimbay folk theater;from 1933 further, he worked as a musician in Turtkul Radio Committee. In 1939 he successfully performed in the competitions of popular talents in the cities of Tashkent and Moscow.

There were 20 eposes on the repertoire of Kiyas Kayratdinov as in Honor of the People's Jiraw of Karakalpakstan.In 1956, he participated in the Tashkent regional conference on the national epos "Alpamys". He recorded more than 24 folk tunes on the tape.

In 1960 he took part in the 25th International Congress of the researchers of the East, where he performed fragments from the national epos "Khirk Khiz". His art was highly appreciated by foreign artists such as Pirna from Czechoslovakia, Kopar from Germany, Pikgen of America, Mohammad from Iran, Ban Din-Zhiaba from Romania, Aynados from Azerbaijan, Sayakbai from Kyrgyzstan, Kenen Azerbaev from Kazakhstan, Hiton from India. "The kobyz is a unic perfect musical instrument, nothing can be compared with it, and Kiyas jiraw is a virtuoso of art", they said unanimously $[14 ; 27]$.

Jumabai Bazarov (1927-2006), a brilliant representative of the jiraws School of the second half of the twentieth century.His repertoire included such well-known epics as "Koblan", "Sharyar", and "Edige" [15;]. Jumabai Bazarov learned this art from Esemurat jiraw Nurabyllaev. Esemurat jiraw was very meticulous teacher, first he made his followers write down the text, and then memorize it.Jumabai was an attentive listener of his mentor; therefore eposes were easy for him to perform.

Over three years Esemurat jiraw learned how to perform the eposes of "Edige", "Koblan", "Sharyar" and many terms and tolgaus.One of them - the melody of "Tolgau" was very melodic though it was sadly in content. The second tune - "Ilgal" was played on a high rhythmic note, often used in eposes. The third tune - "Sybay" often accompanied four or more lined verses. Now it is used in the performance of the song "Give me back my Amu Darya". The fourth tune "Shankay" is used to connect events in eposes.Each tune is used to display a particular story line. These data were presented in an interview held by journalist E.Ermanova [16;12] with Jumabai jiraw Bazarov.

The first independent step as a jiraw he took in 1950 at weddings in the village of the jeweller Nurymbetov. He vividly remembered later his having sung tolgaus and termes before proceeding 
to eposes.He glanced at the opposite side, where another jiraw was improvising, and noticed that the ranks of his listeners had decreased, many of them having gone over to the other jiraw. It gave him new strength, forced to believe in himself [17,27]. In 1960 Jumabai jiraw his work in the district Center of Culture in Shumanay, participated in many competitions and festivals held both in Uzbekistan and abroad, and usually returned with awards.In 1980 he took part in the Third Conference of the Turkic Languages in Tashkent and acquainted its numerous guests with the art of performance of Karakalpak epic poems(dastans). Some pragments of them were recorded on tape by a university professor from the United States, Mrs. Elsa Lausen-Tsirtatel, as well as by a professor of Bonn University, Mr. Karl Reichl.Who studied karakalpak dastans (epic poems) and their improvisers.

With a group of art workers Jumabai jiraw demonstrated his virtuoso art to the audience of Czechoslovakia and among Nogais in Dagestan, Russia, where he performed terms, tolgaus, and scenes from eposes. In 1993 he took part in the national festival of Nauryz organized by students of Moscow universities, who came to study there from Central Asia.In 1994 he participated in the scientific and practical conference in Ashgabat, which was dedicated to the memory of Ashyk Aydyn. In May of the same year he took part in the first International Symposium of Turkic Peoples held in the concert hall of the Kazakh National Academy.

The Kazakh audience liked especially Ormanbet's tolgau, which was repeatedly performed on encore.Here he met for the second time with the professor of Bonn University Karl Reichl, a true admirer and researcher of the Karakalpak folklore, folk music and their performers.

In 1997 at the invitation of Karl Reichl Jumabai jiraw Bazarov, a Professor of Karakalpak State University, and a well-known composer A.Saparova visited Berlin to take part in the international conference devoted to the study of music used in the eposes of the East [18,28].As a result of their creative cooperation Karakalpak folk epics "Sharyar", "Koblan", and "Edige" were recorded. They were published as a book in German and English. On October 18, 2000 in his interview with journalist E.Ermanov Jumabai jiraw noted that epics "Edige" and "Koblan" took him 7 days to sing, and "Sharyar" 3 days $[19,28]$. It should be noted that for the performance of his repertoire, including epics, termes, and tolgaus, the jiraw would need some 20 days. In 2003 Professor Karl Reichl said that he was a true, devoted popularize the art of Karakalpak jiraws and baqsis, who acquainted the East, the West, and America with performers' video discs [20,82]. Jumabai jiraw Bazarov no matter where he visited with concerts, introduced the art of Karakalpak jiraws, the immortal heritage of the Turkic - speaking peoples, to the audience.In 2000, Jumabai jiraw Bazarov was given the honorary title "People's Baqsi of the Republic of Uzbekistan". He handed over his high art to the current generation of grateful followers. He also taught his art to his son Tobanazar Bazarov.

From century to century continues the tradition of preparing followers (learners) for the art of singing of Karakalpak epic songs.People's jiraw of Karakalpakstan Jaksilik Sirimbetov was a pupil of Kiyas jiraw, he learned from him how to sing the epos of "Edige", and plenty of lyric poetry termes, and tolgaus as well.

After the independence the art of Karakalpak jiraws renewed.We can see it in the performances of the new generation of talented jiraws and baqsis.At the age of 14 Bakbergen Sirimbetov began to learn the mastery of jiraws from his father.In 1991 he became the winner of the Republican festival of young performers. He performs passages from the epic poems such as "Alpamys", "Qiriq - qiz", "Edige," Sharyar", "Maspatsha", termes and tolgaus. In 2002 he took part in the international competition «Jingle-the String" (Almaty) and also participated in the festival "Baqsis and Poets" held in 2003 in Kitab district of Uzbekistan. He also participated in the following events: in 2004, in the international festivals of folklore ensembles held in Seoul, Korea, and in Cannes, France, in 2005, at the forum "Melodies of Bards" organized in Amsterdam, Holland, in 2007, at the international festival of "National folklore and Theatre Arts" held in Ashgabat, Turkmenistan [21,7]. Today Bakbergen Sirimbetov is a leading jiraw of the Republic, and has his own school of jiraws. The young jiraw Bakhtiar Esemuratov is a head of the folk and ethnographic ensemble "Amu Tolkyny" and visited Germany and France with his concert programs.He brilliantly plays the kobyz. Now he holds the title of Honored Artist of the Republic of Karakalpakstan.

After the independence of Uzbekistan the Karakalpak art of jiraws and baqsis started to revive. At present People's Jiraw of Karakalpakstan Bakbergen Syrymbetov also has his own school of jiraws. The graduate of this school a young jiraw Janibek Piyazov became the winner of the Republican contest "Kelezhak Ovozi" (The Voice of the Future) organized by the fund "Forum" in 2009.In 2010 he became award winner of several contests: at the international festival "Asrlar Sadosi", republican 
contest "Nihol" and the international competition "Aydin saz "held in Ashgabat, Turkmenistan. He also became the winner of the Tashkent competition of jiraws in 2011. Above all he was recognized by the world music community.In 2011, he became the winner of the international competition of jiraws "Interfolk" held in St. Petersburg, Russia.

\section{Literature:}

1. Косбергенов Р.К. Колониал даўирде қарақалпақ халқының мәденияты хәм турмысы (1873 - 1917). Нукус, издательство «Каракалпакстан», 1970, с. 66 - 69.

2. Алламуратов А. Дүнья мәденияты тарийхы. Қысқаша очерклер.-Нөкис: Билим. 1996. C.35.

3. Айымбетов. Халық даналығы Нукус, «Каракалпакстан», 1988, с. 79.

4. Книга моего деда Коркута. М.- Л. 1962,с.с. 113, 166, 167.

5. Жыраў намалары. Нукус. «Каракалпакстан», 1991, с. 4.

6. Там же, с. 5.

7. Давкараев Н. Очерки по истории дореволюционной каракалпакской литературы. Изд. АН УзССР, Ташкент, 1959, с. 25

8. Айымбетов К. Указанный труд, с. 79-91.

9. Т. Адамбаева. «Жыраў намалары» топламына алғы сөз. Жыраў намалары: Алғы сөз. Саз ноталыры, -Нөкис: Қарақалпақстан, 1991. с. 4-5.

10. Айымбетов. Халық даналығы Нукус, «Каракалпакстан», 1988, с. 83-84.

11. Сагитов И. Т. Қарақалпақ халқының қахарманлық эпосы:-Нөкис, «Қарақалпақстан», 1986. c. 94.

12. Косбергенов Р. Указанный труд, с. 67.

13. Жыраў намалары: Алғы сөз. Саз ноталыры, -Нөкис: Қарақалпақстан, 1991. с. 26.

14. Адамбаева Т. Указанный турд, с. 27.

15. Газета «Еркин Қарақалпақстан», 10 июня 2006 г. №69 (18183)

16. Есенбай Ерманов, Жумабай Жыраў Базаров. Нөкис «Қарақалпақстан» 2000. с. 11-12.

17. Е. Ерманов. Указанный труд. с. 32.

18. Ә.Алымов.,Т.Адамбаева«Атақлы сазгерлер».Нөкис:«Қарақалпақстан» 2012.c. 80.

19. Есенбай Ерманов, Жумабай Жыраў Базаров.Нөкис«Қарақалпақстан» 2000. с. 28.

20. Ә.Алымов.,Т.Адамбаева «Атақлы сазгерлер».Нөкис: «Қарақалпақстан»2012.c. 82

21. Журнал «Сәният». № 3-4. 2011. с. 6-7. 


\title{
ECONOMIC SCIENCES
}

\section{IMPROVING THE MECHANISM OF INNOVATIVE DEVELOPMENT OF REGIONAL TOURISM INFRASTRUCTURE ON THE BASIS OF DIGITAL TECHNOLOGIES}

\author{
Abduraimov Dilshod Muratkulovich, \\ Researcher of Samarkand Institute of Economics and \\ Service. Tel: (90) 603-82-16, E-mail: abduraimovdilshod@mail.ru
}

\begin{abstract}
This article discusses the mechanisms for improving the mechanism of innovative development of regional tourism infrastructure based on digital technologies. The role of the digital economy in the regional development of direct tourism, the role of the digital economy in the development of tourism are explained in detail.
\end{abstract}

Keywords: Domestic Tourism, Tourism Industry, Digital Economy.

\section{INTRODUCTION}

The Action Strategy for the Development of the Republic of Uzbekistan for 2017-2021 also identifies "... rapid development of the tourism industry, diversification and improvement of quality of tourist services, expansion of tourism infrastructure" as one of the important areas. Short-term growth in the volume of recreational services based on the effective management of tourism and recreational activities and the development of the industry, on the one hand, leads to an increase in domestic tourism consumption in the country, on the other hand, increases the share of tourist services in exports. has a positive effect.

Today, the tourism industry has become one of the leading sectors of the world economy. In this regard, special attention is paid in Uzbekistan to the modernization of the tourism industry, the improvement of the regulatory framework for sustainable development of the industry, the provision of services in accordance with international standards. Today, the role of tourism, which is one of the most important sectors of the economy, is very large and important. The development of the tourism industry is associated with the complexity of production, the saturation of the consumer market with goods based on daily and personal demand, the rapid growth of scientific and technological progress that renews the life of society.

At present, the development of the digital economy in the world is accelerating. The development of the digital economy will allow to fully meet consumer demand and increase labor productivity in sectors and industries of the economy. E-commerce allows to prevent crises by accelerating the sale of goods and services. At the same time, the virtual payment system accelerates the turnover. Internet advertising, in turn, allows you to expand your advertising audience around the world.

\section{LITERATURE REVIEW}

The following scholars have studied improving the mechanism of innovative development of regional tourism infrastructure based on digital technologies in their literature Arkhipova V.F. [1], Ernazarov O.E. [2], Birzhakov M.B. [3], Zhukova M.A. [4], Mirzaev A.T. [5], Morozov M.A. [6].

\section{RESEARCH METHODOLOGY}

In this research, we used of methods of analysis and synthesis, grouping, comparative and structural analysis, induction and deduction

\section{ANALYSIS AND RESULTS}

An important factor in the success of the digital economy is a new model of information and management technologies for the state, business and civil society, which envisages the modeling of future situations and problems and the implementation of operational interventions.

It should be noted that if the entities engaged in tourism activities want to fully deliver their products to tourists, they must use modern information and communication methods. The tourism business has its own websites, social media or popular online platforms among travelers, in particular sites such as Booking.com, Trip Advisor, Expedia, Cheapair, and their strategic activities are the basis of an innovative approach to marketing. Ratings formed on the basis of the prices for services provided to tourists are a real advertising, public relations (PR) mechanism for companies that offer 
quality tourism products.

At present, the tourism industry in our country is developing in accordance with the requirements of the world tourism market. Today, a tourist planning to visit the country can plan a trip via the Internet, use the online services of hotels and airlines. In the regions of the country, the opportunities for using taxi services on special mobile applications on smartphones, ordering food, booking places in restaurants or getting information about their destinations from the Internet are expanding.

Oriental Express CA, the largest and fastest growing online agency in Central Asia and the Caucasus, is actively involved in the widespread introduction of tourism services in the country. Hotelios, an Internet information exchange service between tour operators and hotels, has been launched in Uzbekistan. This system is an innovative project that has no analogues among the CIS countries. The possibility of obtaining insurance policies online has been introduced in the country.

Today, the development of innovative activities in the country has created conditions for the widespread introduction of information and communication technologies. It is also necessary to explore ways to increase the transparency and attractiveness of these technologies in various areas and directions, the effective use of opportunities for the development of bilateral relations between the participants in the exchange of information. In recent years, the tourism industry is becoming an actively developing sector of the economy that requires innovations based on digital technologies. The development of entrepreneurship in tourism has its own characteristics, and changes in the field of information and communication technologies play a special role in its development.

The development of the tourism industry is a task of national importance, which stimulates the socio-economic growth of the regions through the cumulative effect of the formation of interconnected industries and makes a worthy contribution to the formation of the country's image through foreign countries. The role of innovations in the field of tourism and recreation is reflected, firstly, in the face of international competition in the context of globalization, and secondly, in the effective use of regional tourist resources.

Classification of innovations in the field of tourism and recreation

\begin{tabular}{|c|c|c|}
\hline $\begin{array}{c}\text { The object of innovative } \\
\text { activity }\end{array}$ & $\begin{array}{c}\text { Appearances of } \\
\text { innovation }\end{array}$ & Description \\
\hline \multirow{2}{*}{ Tourism products and services } & Conceptual & $\begin{array}{l}\text { Introduction of new technologies and } \\
\text { methods }\end{array}$ \\
\hline & Updated & $\begin{array}{l}\text { A new combination of existing ser- } \\
\text { vices }\end{array}$ \\
\hline Tourist resources & Resource & $\begin{array}{c}\text { Using of new-looking tourist resourc- } \\
\text { es }\end{array}$ \\
\hline \multirow{2}{*}{$\begin{array}{l}\text { Business processes in the busi- } \\
\text { ness industry }\end{array}$} & Marketing & $\begin{array}{c}\text { New approaches to the organization } \\
\text { of marketing activities }\end{array}$ \\
\hline & Logistics & $\begin{array}{l}\text { New solutions in the system of deliv- } \\
\text { ery, distribution and supply of tourist } \\
\text { products }\end{array}$ \\
\hline $\begin{array}{l}\text { Institutional environment in the } \\
\text { tourism industry }\end{array}$ & Architectural style & $\begin{array}{l}\text { Transformation of the structure, rules } \\
\text { and models of tourism activities }\end{array}$ \\
\hline $\begin{array}{c}\text { Organization of production and } \\
\text { management in the tourism } \\
\text { industry }\end{array}$ & Management style & $\begin{array}{c}\text { Improving the professional skills and } \\
\text { qualifications of employees, improv- } \\
\text { ing the quality of services, increasing } \\
\text { labor productivity }\end{array}$ \\
\hline
\end{tabular}

Many researchers have come to the conclusion that ensuring innovation activity in the tourism industry is aimed at overcoming the existing shortcomings and deficiencies in the tourism industry. In our opinion, innovations in the field of tourism are somewhat improved methods of production and supply, which are new in content or can not be provided on the basis of previous production methods. These include tourism, banking, consulting services, modern information and communication technologies. A classification of innovations depending on the object of innovative activity in the 
tourism industry has been developed (Table 1).

\section{CONCLUSION/RECOMMENDATIONS}

Equipping enterprises in the tourism industry with information and communication technologies will reduce the time spent on the exchange of information and increase the efficiency of services between the tourism enterprise and its departments, as well as between the enterprise and its counterparties. As a result, this will lead to an increase in labor costs and increase sales of tourism products and increase incomes.

Therefore, the digital economy plays a very important role in the development of tourism. The full involvement of the digital economy in tourism will further increase both economic and social efficiency in tourism.

\section{References}

1. Arkhipova V.F., Devizov A.S. On infrastructure as a determining factor in the development of tourism in the region. URL: http: //www.roman.by/r-78201.html;

2. Ernazarov O.E. Methods of Evaluating the Efficiency of Innovations in Industrial Enterprises. International Journal of Research - 2020. - Volume 07 - Issue 07. Available at https://journals. pen2print.org/index.php/ijr;

3. Birzhakov M.B. Introduction to tourism. - SPb .: Gerda Publishing House, 2004;

4. Zhukova M.A. Management in the tourism business: a textbook. - 2nd ed., Erased. - M .: Competition, 2006 .-- 193 p., $14^{\text {th }}$ p;

5. Mirzaev A.T. Methodology for assessing the resource component of innovative potential in the management of tourist and recreational clusters. Scientific electronic journal "Economy and Innovative Technologies”. № 4, July-August, 2020;

6. Morozov M.A. Infrastructure support of entrepreneurial activity in tourism: monograph. - M .: RosNOU, 2005;

7. Decree of the President of the Republic of Uzbekistan No. PF-4947 of February 7, 2017 "On the Action Strategy for the further development of the Republic of Uzbekistan." Collection of Legislation of the Republic of Uzbekistan, 2017, No. 6, Article 70. 
THE ESSENCE OF THE FINANCIAL SYSTEM AND INFRASTRUCTURE.

\author{
Khudoyberdiev Yusufjon Ollomurod oglu \\ Master of Public Finance and International Finance, \\ Tashkent State University of Economics
}

\begin{abstract}
Annotation: This article discusses financial infrastructure, the financial system, and their place in our lives.
\end{abstract}

Keywords: financial system, infrastructure, role of finance, budget

A set of markets and other institutions used to make financial transactions, exchange assets and risk is called a financial system. The financial system includes financial services markets, intermediaries and firms, as well as households, private companies and other institutions that use them to make financial decisions.

Based on the analysis of the main function of the financial system, which consists of the efficient distribution of financial resources, at a more general level of analysis, we can talk about the following six basic (essential) or important functions of the system

They can be summarized as follows:

- provide a way for economic resources to move (relocate) over time (periods), across national borders, and from one sector of the economy to another;

- risk management (provision of risk management methods;

- trading and clearing methods that allow trading;

- Consolidation of financial resources and provision of a mechanism for the division of ownership in different enterprises;

- Providing pricing information that allows the coordination of decentralized decision-making processes in various sectors of the economy;

- Provide solutions to stimulus problems.

The flow of resources from economic entities with surplus financial resources to economic entities with scarce financial resources is called financial flow. It is impossible to imagine a financial system without financial flows. Without them, the financial system would be "empty." Without financial flows, there is no need for a financial system. In this case, it becomes "something worth a penny." Therefore, the interactions (flows) between the main participants of the financial system are shown. They reflect the movement of financial flows, in the most general way. According to him, funds flow through various elements of the structure of the financial system from companies with overfunds to companies with deficits. For example, a family whose members have accumulated (saved) part of their current income to use it as a pension in the future will have free financial resources. Another family that wants to buy a new home feels the need.

Firms with more income than they need in the financial resources needed to carry out investment projects are referred to as over-capitalized entities; firms that lack resources for future investments are referred to as resource-deficient entities

In sole proprietorships, and even in many companies, the business owner acts as a manager at the same time. However, in other firms, especially large ones, property owners do not run the business themselves. They delegate this task (responsibility) to professionals (special professions). In many cases, these professionals are not even shareholders of the company. There are at least five reasons why property owners should entrust the management of a company to a management specialist.

First of all, it is not difficult to find professional managers who know their profession well. At the same time, they may be better prepared (and often will be) to run a company than business owners, have more experience, and simply have better human qualities. The owner of the property he manages must have not only the financial resources needed to run the business, but also the managerial ability. The separation of ownership of a company's property from its management does not require such a partnership, which is rare in nature.

Let's look at an example of this in the entertainment business. For example, people with a high degree of management in a film studio or television network may not have the financial resources to set up their own business in this field, and conversely, a wealthy person with sufficient funds may not have the necessary skills to run such an organization. So, the best way out of this situation is for skilled professionals to make, produce and sell films, and for the rich to provide the business with the 
right amount of capital.

The corporate form of business organization is especially effective when property rights are separated from management. Because it allows frequent changes in the list of owners without compromising the healthy (normal) operation of the firm (due to the transfer of ownership to the shares). Millions of shares of various corporations are held in the hands of companies around the world, and there are very few cases where this has negatively affected the quality of the company's management and operations.

\section{References:}

1. A.V. Vohobov , T.S.Malikov "Moliya" Tashkent 2012.

2. T.Malikov, O.Olimjonov "Moliya" Tashkent 2014 


\title{
TRENDS IN THE DEVELOPMENT OF INTERNET TECHNOLOGIES IN THE ERA OF DIGITALIZATION OF THE ECONOMY
}

\author{
Tursunova Munisa Khujayor qizi \\ Student \\ Joint Faculty of Tashkent Financial \\ Institute and Polotsk State University \\ monika-0130@mail.ru \\ Tursunova Ibodat Khujayor qizi \\ Master's degree student \\ Tashkent Financial Institute \\ Tashkent, Uzbekistan \\ tursunovaibodat97@gmail.com
}

Annotation: At present, the digital industry has spanned the entire world, and various industries, such as energy, industrial production, ports and transport, are actively exploring digital transformation.

Keywords: digital industry, digital transformation, technology, economy, information data.

Most importantly, a new round of technological revolution and industrial transformation is taking place all over the world. The new generation of digital technologies represented by $5 \mathrm{G}$, big data, cloud computing and is rapidly changing. The digital and intellectual transformation of traditional industries is inevitable. Currently, the development of $5 \mathrm{G}$ has entered a key stage of integration and innovation, and there is a trend of multi-subject cooperation between communication service providers, equipment manufacturers and vertical industries. As the main engine of new infrastructure construction, $5 \mathrm{G}$ has huge potential in supporting the digital, networked, and intelligent transformation of the social economy. Considering the history of the development of industrial society over the past 300 years, we can say that this is the most important process of continuous improvement of production methods and optimization of the level of division of labor and cooperation. The new era of the digital economy begins with large-scale production, retail and circulation. The division of labor and cooperation are transformed from closed to open, from localization to globalization.

It should be noted that in the era of the agrarian economy, tools and human resources are the main factors of production that maximize the role of man. In the era of the industrial economy, the invention of steam engines and electricity forced us to go beyond the physical capabilities of man. Now, in the era of the digital economy, information data is expected to function as new key innovation elements to make possible new combinations of key production factors, which will eventually help to exceed the limitations of human mental abilities. To solve various problems in the data transfer process, differentiated solutions are required, allowing you to flexibly configure different industries to work with data connectivity. In addition, in terms of performance, simpler methods are required to reduce the cost of deploying users. Cost is a key issue for the transformation of the digital economy of enterprises. From the point of view of the overall strategy, technical feasibility can be considered first, and then optimizing the effect and cost. Only through such cyclical iterations can the digital economy develop at a faster pace.

In terms of digitalizing the entire industry, improving the capabilities of these connections requires iteration. In the previous industry, the main activities were data collection and control. Each device has sensors. After receiving the data, the device decides exactly what actions (digital applications) will be performed through its locally defined calculation. In the traditional process, intelligence and the data network are not fully used, which leads to a low level of the entire industry. Therefore, for the application of 5G, AI( artificial intelligence), big data and other new technologies, it is necessary to first strengthen the connection from the original internal data cycle to the external data cycle of the entire system in order to maximize the use of data.

Every previous new generation of mobile networks has so far increased energy consumption and carbon emissions. $5 \mathrm{G}$ is the most energy-efficient standard ever developed, and it will help break this trend in the mobile sector. In addition, ICT solutions can achieve a 15 percent reduction in other industries by 2030[1]. By 2030, two-thirds of the world's workforce will use the 5G platform. New technologies supported by $5 \mathrm{G}$ will reduce consumption and emissions by $15 \%$.By 2024 , mobile broadband will provide network coverage to $92 \%$ of the world's population[2]. In the process of 
moving mobile communications from generation to generation, $5 \mathrm{G}$ is the first generation to focus on supporting applications in vertical industries. $5 \mathrm{G}$ can profoundly expand the capabilities of vertical industry applications with completely new air interface capabilities, service network architecture, end-to-end network slicing, and edge computing that can meet differentiated and defined industry service requirements.

In conclusion, it should be noted that the trend of the digital economy brings many opportunities for the development of transformation and modernization of various vertical industries. The key to capturing opportunities is how to accelerate the digitalization of businesses as soon as possible with a flexible and user-friendly solution. At the present stage, rapid deployment of a private network and applications is the basis for success. With the accumulation of success stories, this accelerates the development of the digital economy throughout the industry.

\section{References}

1. [Electronic resource] Mode of access: https https://www.ericsson.com/en/blog/2020/1/davos2020-innovation-in-5g-enabled-digital-economy

2. World Economic Forum [Electronic resource] Mode of access: https https://www.weforum. org/agenda/2020/01/3-ways-to-boost-innovation-in-the-5g-enabled-digital-economy 


\title{
HISTORICAL SCIENCES
}

\section{THE HISTORY OF HELICOPTER TRANSPORT IN UZBEKISTAN}

Tukhtabaev Azamjon Sharipkhujaevich

Senior lecturer

Namangan State University toxtabayev2012@mail.ru

\begin{abstract}
This article highlights the history of the organization of helicopter transport in Uzbekistan during the Soviet Union period, as well as the origins and activities of helicopters used in Uzbekistan. In addition, the article also provides information on the structure of Mi-1, Mi-2, Mi-4 and $\mathrm{Ka}-26$ helicopters.
\end{abstract}

Keywords: air transport, helicopter, Mi-1, Mi-2, Mi-4, Ka-26.

It is obvious that helicopter(s) was as significant as aircraft(s). Helicopters with 20-40 seats were used to reach destinations located in the mountainous areas and difficult-to-reach territories [3, p. 4]. The first two helicopters of Uzbek aviators were delivered in 1956, and the first fly was conducted by B.M.Borisov [4, p. 65]. In 1956, Mi-4 helicopters were brought to Tashkent [2, p. 34]. Mi-4 helicopters were used, in May 1956, to search for natural resources in the Karakum and Kyzylkum deserts.

The Mi-4 was the first military vehicle of the USSR Armed Forces, which was a multi-mission helicopter produced in the early 1950s. This helicopter was equipped with a cargo hatch at the rear and a descending path. During 1950-1970, it was the main transport and landing helicopter for the countries that joined the Warsaw Pact. The production, flight testing and serial production of this helicopter took place in a record time - a year. The Mi-4 was the first helicopter used in the USSR for crane and assembly work. At the World's Fair in Brussels in 1958, the Mi-4 was awarded a gold medal and a diploma.

In 1958, 6 units of Mi-1, 6 units of Ka-15 and Ka-18 helicopters were delivered to Tashkent. As a result, the number of helicopters increased and there was a need to establish a specialized unit. A helicopter air squadron was formed in 161-PO under the command of Boris Miroshkin, and in January 1960 a helicopter air squadron was formed under the command of Gneorgiy Sheverdyaev.

The Mi-1 was the first multi-mission Soviet helicopter, which was 2594 units produced between 1950 and 1965. The helicopter was used for cargo and passenger transportation, as well as for special missions. The Mi-1 began to be commonly used in Land Forces Communication Division, then in special squads of helicopters and flight schools. For a long time, the Mi-1 was the main type of training helicopter in the USSR. The civil aviation began to use the Mi-1 in February 1954. A few years later, the Mi-1 was used by Aeroflot throughout the USSR. The use of Mi-2 helicopters stared in 1967. In the fall of 1970, the Mi-8 helicopter was delivered to Tashkent.

The Mi-2 was a multi-mission helicopter produced by a design bureau under the leadership of M.L.Mile in the early 1960s. The series production started in 1965 and the helicopter was used for various civilian and military missions. By 1992, more than 5400 units of this helicopter had been produced.

Today hundreds of Mi-2 helicopters are operating in more than 20 countries.

Starting from 1973, in accordance with the new Aeroflot standards, the original red-white-gray and green-white color schemes have been replaced by blue-white-gray. The Mi-2 helicopters flying in the Far North and Far East are painted orange-blue for more visibility against a background of snow and ice during an emergency landing.

The Mi-2 helicopters can be used in agriculture (spraying and dusting of forest and agricultural lands), including freight and passenger transport. There are also rescue and polar versions of this type of transport, which are equipped with radio and navigation tools for operation in adverse weather conditions. A patrol version was created for special services, which was used to fly across borders. In naval aviation, ice-breaker ships carried the Mi-2 to help explore ice conditions, and it was also used 
for communication between ships.

Czechoslovakia purchased a Mi-2 helicopter with special equipment for transport control in 1974. In Bulgaria, a Mi-2 equipped with radar equipment was used to monitor the pollution of the Black Sea. The version specialized for agricultural use was also common; it was used in the USSR, Poland, and Hungary.

By this time, this helicopter had become one of the mostly utilized in Central Asia. They were used for cargo transportation, gas pipeline laying, construction of power lines, construction of multistorey buildings, as well as for reaching hard-to-reach areas by weather experts. Helicopters have eased the work of paramedics, who help people living in the mountains and deserts, including oil workers and gas workers. The members of the squad helped to develop the fields north of Tyumen and Nefteyugansk [1, p. 506]. They operated not only in Central Asia, but also in Yakutia, Tyumen, Krasnoyarsk Krai and the Far East. Besides, Uzbek helicopters helped teams from Kyrgyzstan, Turkmenistan and Tajikistan learn the secrets of the profession. In addition to the 5th PB in Tashkent, there were divisions using KA-26 helicopters in Kokand and Mi-2 helicopters in Urgench [5, p. 30].

The Ka-26 is a Soviet multi-mission helicopter developed by the Kamov Design Bureau. It was produced in 816 number (units), from which 257 units were delivered to 14 countries around the world. This helicopter was mainly used for civilian purposes, but it was also used by the Bulgarian and Hungarian air forces, the GDR and the GFR police.

The Ka-26 helicopter was used for the following purposes (versions of the helicopter): agriculture, transport, sanitation, forest guard, flying crane, ship rescue, magnetic search, and geological exploration (with a ring antenna mounted around the fuselage). What is more, it performed chemical work in the national economy and aviation in the USSR.

In conclusion, during the former Soviet Union helicopters were utilized in agriculture, especially widely used in industrial development in Uzbekistan. This gave a big stimulus to the production of new models of modern, comfortable and reliable helicopters.

\section{Reference books:}

1. Civil aviation of Russia. 80 years old. - M.: Air transport, 2003. - p. 506.

2. Civil aviation. - 1956. - No. 6. - p. 34.

3. Civil aviation. - 1971. - No. 4. - p. 4.

4. Tyurikov V. First ... first ... first .... - Tashkent: Uzbekiston, 1996 . - p. 65.

5. Uzbekistan Aviation is 70 years old. - Tashkent, 1994 . - p. 27. 


\title{
CHEMICAL SCIENCES
}

\section{PHYSIOLOGICALLY ACTIVE POLYMERS WITH ANTITUBERCULOSIS ACTIVITY.}

\author{
S.Arslanov, E. Egamberdiev, G.Akmalova \\ el.0919@mail.ru \\ Tashkent Institute of Chemistry and Technology
}

Tuberculosis, being one of the main causes of disability and premature mortality of patients with this disease, causes significant harm to the health of the population and, accordingly, to the economy of the state as a whole, which determines the urgent need for new ways of their treatment [1].

One of these ways is the synthesis of polymeric materials with anti-tuberculosis activity based on a natural polymer - cellulose and its water-soluble derivatives and a low-molecular substance isonicotinic acid hydrazide (tubazide) in order to prolong its action.

An analysis of the literature on physiologically active polymers (FAP) leads to the conclusion that the information accumulated in this area allows already at this stage to satisfy many practical requests from various fields of medicine. In this case, it is advisable to use for the synthesis of FAP polymers and drugs, which have been sufficiently tested in practice.

Currently, the interest of researchers working with polymers for medical purposes is caused by cellulose and especially its hydrophilic water-soluble derivatives, in particular, ethers and esters. High solubility in water, ease of preparation and physiological indifference of cellulose ethers ensure their relative harmlessness.

Such cellulose ethers include water-soluble cellulose acetate (WSCA) synthesized in [2], since it has significant positive qualities that distinguish it from other water-soluble cellulose ethers. The presence of hydrophilic-hydrophobic functions, due to hydroxyl and acetyl groups, gives it permeability through the lipid membranes of body cells. It is stable at blood plasma $\mathrm{pH}$ in addition, as was established in the work of N.I. Akhundova. [3], acetylation and hydrolysis processes take place in the body under the action of the COA (Coenzyme) enzyme. In this regard, water-soluble cellulose acetate is the only and suitable object where you can use these processes in the right direction in order to regulate the residence time or resorption of products from it (fiber, film) in the body.

All these advantages of (WSCA) allowed us to conclude that it is advisable to use it to obtain FAP.

In order to expand the range of anti-tuberculosis drugs, such drugs were first obtained on the basis of (WSCA) and tubazide. For the addition of tubazide to VRAC by chemical bond, aldehyde groups were introduced into the structure of VRAC by oxidation with iodic acid.

By changing the time of exposure of iodic acid to (WSCA), the content of aldehyde groups in it was regulated.

To confirm the formation of the aldehyde group in the (WSCA) after oxidation with iodic acid, the IR spectra of the control and oxidized samples were recorded. Since the absorption bands of the aldehyde groups coincide with the bands of the acetyl groups, the IR spectra of the saponified (WSCA) samples were taken to prove the formation of aldehyde groups. Saponification of oxidized (WSCA) was carried out under mild conditions with a $0.5 \mathrm{~N}$ solution of sodium methoxide in anhydrous methanol, providing complete elimination of acetyl groups. It was found that in the oxidized (WSCA) in the region of $1740 \mathrm{~cm}-1$ there appears an absorption band belonging to the aldehyde group and the intensity of which was the higher, the deeper the oxidation of the (WSCA) sample was. WSCA sample containing aldehyde groups was treated with an aqueous solution of tubazide, precipitated in acetone, and dried. The reaction was carried out at a temperature of 293-295 K, in a neutral medium, with a bath modulus of 1:50. The product was purified by double precipitation in acetone.

The reaction of oxidized WSCA with tubazide can be depicted as follows: 

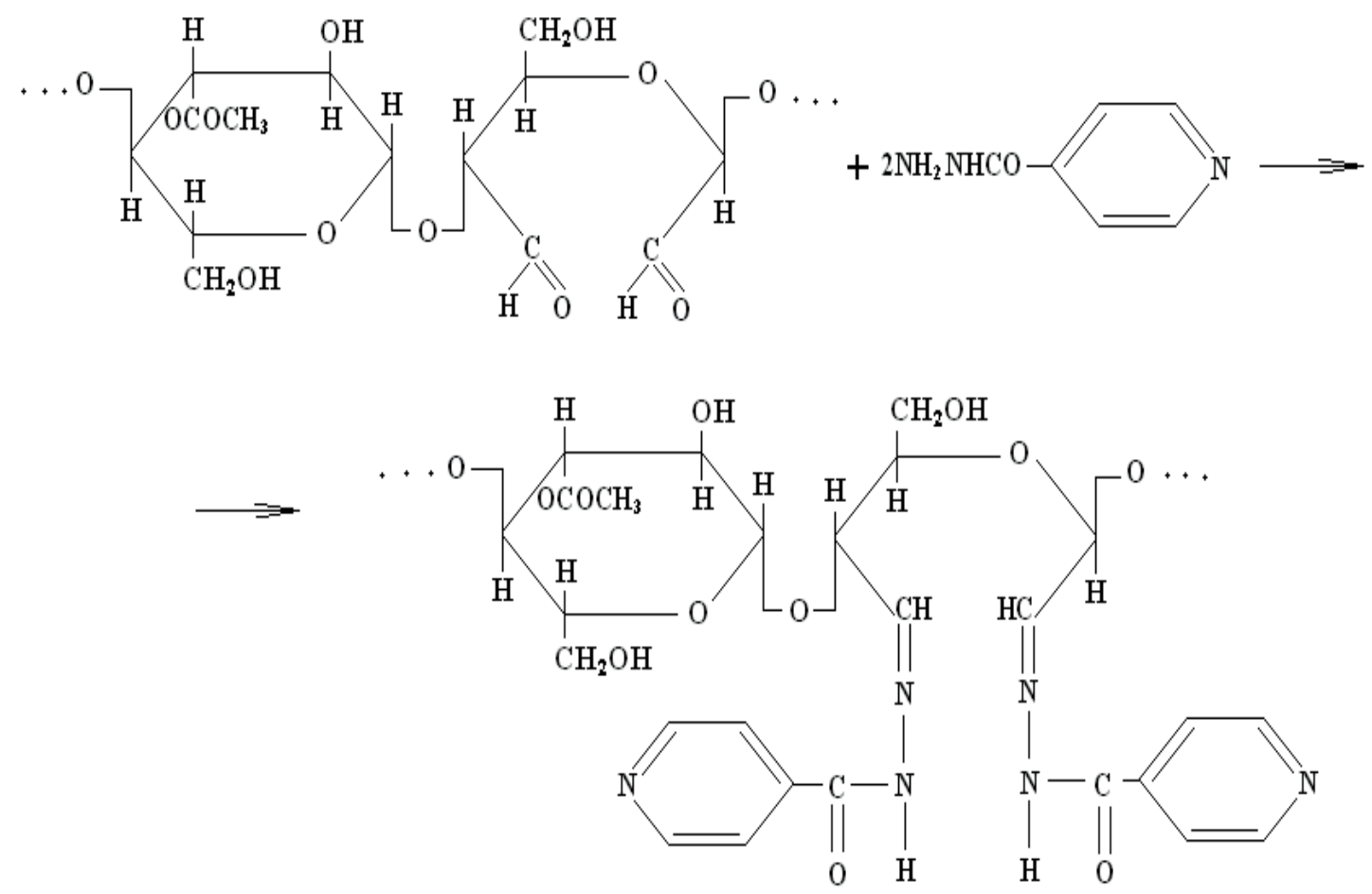

The change in the content of tubazide in WSCA depending on the amount of aldehyde groups is given in table 1.

Composition of the products of interaction of oxidized WSCA with tubazide.

\begin{tabular}{|c|c|c|c|c|c|}
\hline $\begin{array}{c}\text { Oxidation time, } \\
\text { min. }\end{array}$ & $\begin{array}{c}\text { Number of } \\
\text { alds. groups for } \\
\text { 100AGZ. }\end{array}$ & $\begin{array}{c}\text { Number of St. } \\
\text { acetic acid }\end{array}$ & $\begin{array}{c}\text { Nitrogen content, } \\
\%\end{array}$ & $\begin{array}{c}\text { Tubazide content, } \\
\%\end{array}$ & $\begin{array}{c}\text { Solubility in Ringer's } \\
\text { solution. }\end{array}$ \\
\hline 30 & 14.2 & 18.0 & 1.1 & 3.2 & $\mathrm{P}$ \\
\hline 60 & 18.2 & 17.1 & 2.7 & 6.1 & $\mathrm{P}$ \\
\hline 120 & 35.9 & 17.8 & 3.1 & 8.4 & $\mathrm{P}$ \\
\hline 180 & 43.2 & 15.6 & 3.8 & 10.1 & $\mathrm{H}$ \\
\hline
\end{tabular}

As can be seen from the data in the table, with an increase in the oxidation time, the amount of aldehyde groups increases and, accordingly, the amount of added tubazide. However, an increase in the content of aldehyde groups over a certain limit (more than 40 per $100 \mathrm{AHZ}$ ) is impractical, since tubazide-containing products obtained on the basis of such preparations lost their solubility in water and in Ringer's solution. This is apparently due to a decrease in the amount of bound acetic acid (up to 15\%) and the formation of hemiacetal bonds within one molecule and between neighboring macromolecules.

It should also be noted that no more than $50 \%$ of aldehyde groups interact with tubazide. This circumstance is explained by the fact that some of the aldehyde groups at the second and third carbon atoms are in a hemiacetal bond with the primary hydroxyl group of the elementary unit of cellulose.

In the IR spectrum of oxidized WSCA treated with tubazide, with an increase in the oxidation time, an increase in the absorption bands at 1680, 1600, 1560, 1500, 850, $760 \mathrm{~cm}-1$ is observed, which indicates the chemical interaction of oxidized WSCA with tubazide with the formation of - $\mathrm{C}-\mathrm{N}$ communication $(1680 \mathrm{~cm}-1)$. 


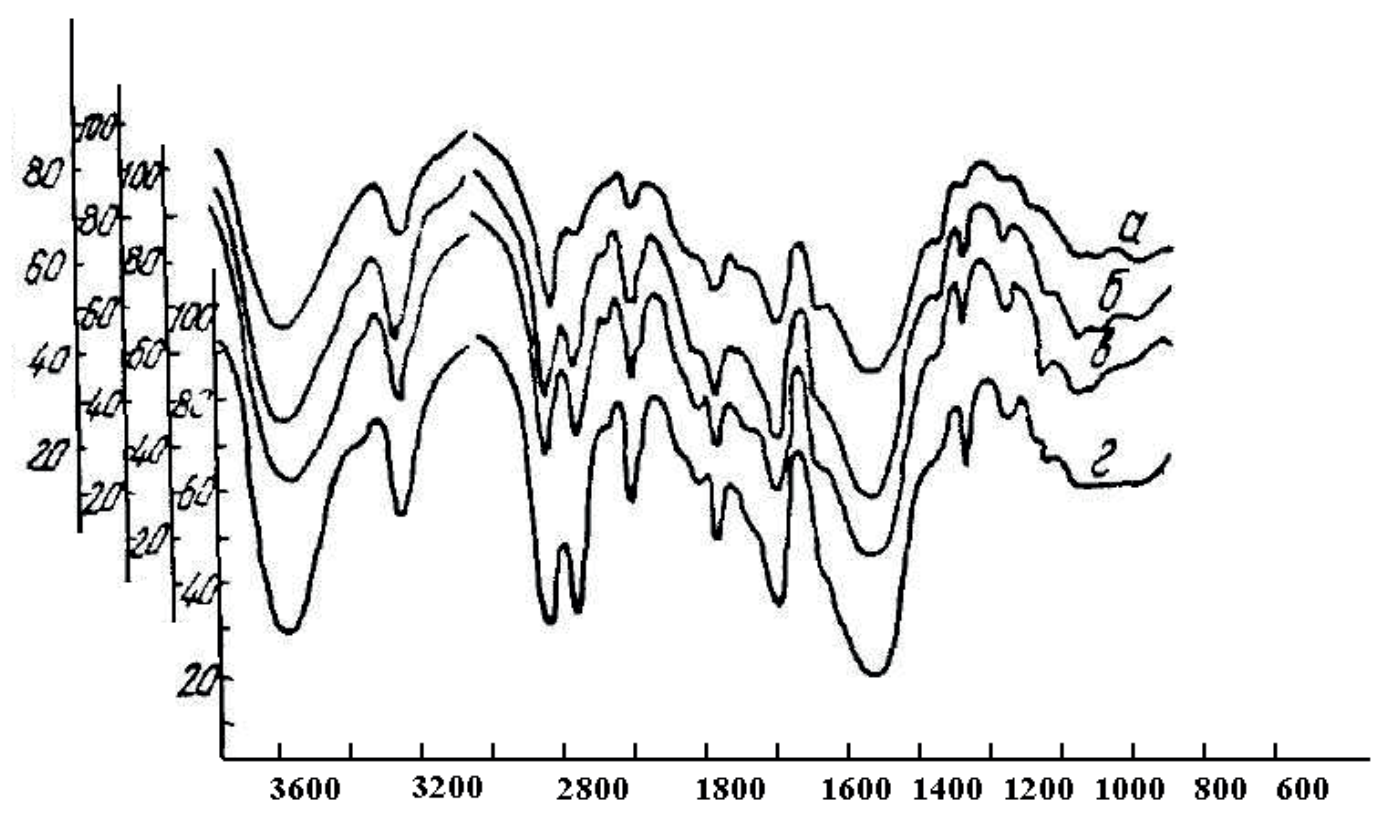

IR absorption spectra of oxidized WSCA treated with tubazide

$\mathrm{a}-30 \mathrm{~h}$ oxidation, $\mathrm{b}-60 \mathrm{~h}$ oxidation,

c - 120 h oxidation, $\mathrm{d}-180 \mathrm{~h}$ oxidation

The materials obtained were examined at the Republican Specialized Research Medical Center for Phthisiology and Pulmonology, where they showed high anti-tuberculosis activity.

\section{Literature}

1. Alimova Kh.P. Socio-hygienic study of characteristics tuberculosis in children and adolescents and ways to improve it prevention. Auth. diss. for the degree of Candidate of Science. honey. sciences. T., 2004, p. 21.

2. Rakhmanberdiev G.R., Petropavlovsky G.A., Usmanov H.U. Water-soluble cellulose acetate, its properties and capabilities application. Cell. Chem. And Technol. 1978, Vol. 12, No. 2, pp. 147-159.

3. Akhundova N.I. Inactivation of isonicotinic hydrazide preparations acid and its relationship with drug resistance of microbacteria tuberculosis. Abstract of the thesis. diss. on sois. Cand. honey. sciences. Baku. 1969, p. 21. 


\title{
PEDAGOGICAL SCIENCES
}

\section{METHODOLOGY OF TEACHING ON "APPLICATION OF CLOUDTY TECHNOLOGIES IN EDUCATION” WITH ABCD METHOD}

\author{
Abdusamatova Shaxodat Hojiakbar qizi, Yuldasheva Maftuna Zokir qizi \\ Tashkent University of Information Technologies named \\ after Muhammad al-Khwarizmi students of vocational education in the field of ICT \\ Tel: +998933754215, e-mail: abdusamatovashahodat@gmail.com
}

\begin{abstract}
Annotation: This article deals with the issues of teaching the use of cloud technologies in the educational process on the basis of a modern new method, the mobility and debate of the method to be interesting for students.
\end{abstract}

Keywords: method, technology, learning process, cloud technology, cloud computing, cloud technology in education

Further improvement of the field of pedagogical education, the provision of professional teaching staff with the skills to apply modern knowledge and pedagogical technologies, the training of highly qualified specialists who will make a worthy contribution to the socio-economic development of the country, the introduction of advanced educational technologies In order to implement, as well as to implement the tasks set out in the Address of the President of the Republic of Uzbekistan to the Oliy Majlis on January 24, 2020, the following action plan was developed on the decision of President Shavkat Mirziyoyev ${ }^{4}$ :

training of professional teachers who have a thorough knowledge of teaching and learning methods, information and communication technologies and foreign languages, the ability to use modern pedagogical technologies in the educational process;

Improvement of curricula and programs in the field of pedagogical education in the field of education and specialties on the basis of advanced foreign experience, the creation and implementation of innovative teaching and learning resources and others defined the future prospects of education and pedagogy of our country.

In order to ensure the implementation of the above decree, the technologies and methods of teaching and learning in pedagogy and many other disciplines have been revised and the introduction of modern methods and technologies has been gradually phased out of traditional teaching methods. Targeted projects on introduction of practice are being implemented. In particular, in order to make the lessons more meaningful and interesting, many modern and innovative teachers use many methods and technologies, of which in this article we will discuss the topic "Application of cloud technologies in education" using the method "ABCD". rib out.

\section{Application of the method "ABCD"}

Step 1. To form a preliminary understanding of the topic being studied by the teacher

Step 2. In order to further strengthen the lesson, the following method is explained to the students of the auditorium using the method of "ABCD". To use this method, students must answer the following questions. Students are given a topic or problem and discussed it using the ABCD method for each letter: A - audience, B - behavior, C - situation, D - skill level, how to answer the question begins to find.

Step 3. Students will be introduced to the method and will be given the following sample:

Topic: The use of cloud technologies in education

A - audience. Cloud technology is the best tool for virtual audiences

B - behavior. It should be in line with the culture of the Internet

\footnotetext{
${ }^{4}$ To the Resolution of the President of the Republic of Uzbekistan dated February 27, 2020 No. PP-4623
}

January-February, 2021 
C is the case, it is effective to use education when there is a need for these technologies D - skill level words. Skills were available to use cloud technology

Step 4. After the students have developed the method for the given sample, all the results are combined and a general conclusion is made.

\section{References}

1. To the order of the President of the Republic of Uzbekistan from February 27, 2020 of No. PP4623

2. DA Zaripova (Phd) Laboratory classes on "Educational Technologies" (Methodical instructions)

3. Textbook "Pedagogical Psychology" Ibragimov HI, Yuldashev UA, Bobomirzaev H. Publishing House of the National Society of Philosophers of Uzbekistan Tashkent 2009 


\title{
THE NATIONAL QUALIFICATIONS FRAMEWORKS AND ITS DEVELOPMENT IN UZBEKISTAN
}

\author{
Gulrukh M. Mirkhodjaeva \\ Turin Polytechnic University in Tashkent
}

\begin{abstract}
This article discusses the development of National Qualifications Frameworks in Uzbekistan after becoming independent republic, as well as indicates the comparability of different qualifications and how one can progress from one level to another, within and across occupations or industrial sectors (and even across vocational and academic fields.
\end{abstract}

Key words: qualification, quality, vocational education, secondary education, skills

What is NQS (National Qualifications Framework)?

A Qualifications Framework is an instrument for the development, classification and recognition of skills, knowledge and competencies along a continuum of agreed levels. It is a way of structuring existing and new qualifications, which are defined by learning outcomes, i.e. clear statements of what the learner must know or be able to do whether learned in a classroom, on-the-job, or less formally.

Many countries have introduced - or are considering the introduction of - a National Qualifications Framework (NQF). These countries as well as Uzbekistan believe that NQFs can help to ensure that qualifications meet the country's economic and social needs, are of good quality, provide flexibility and progression for learners, and enjoy international recognition.

The pace of NQF introduction internationally is such that it is difficult to be sure that any list of developments is completely up-to-date. However, according to the data shown in "An Introductory Guide to National Qualifications Frameworks: Conceptual and Practical Issues for Policy Makers» gives some indication of the extent of NQF introduction across the world. Uzbekistan also is between countries which are in the 3 rd Generation (currently under consideration) as Albania, Angola, Barbados, Bosnia and Herzegovina, Botswana, Brazil, Chile, China, Colombia, Democratic Republic of Congo, Jamaica, Lesotho, Macedonia, Malawi, Mozambique, Romania, Serbia, Slovenia, Tanzania, Turkey, Uganda, Zambia, Zimbabwe. [2]

For the first time in Uzbekistan, the National Qualifications Framework is approved. On May 15 of this year 2020, the Cabinet of Ministers adopted the Measures to organize activities of the National System of Advancing Qualification, Knowledge and Skills in Uzbekistan Resolution. [1]

Over many years, there have been mismatch of vocational education programs in Uzbekistan with the International Standard Classification of Education (ISCED) adopted by UNESCO, the National Qualification System of Uzbekistan has not been duly introduced into the educational process.

In order to eliminate these shortcomings, fundamentally reform the existing system of vocational education, and establish an entirely new vocational education system through the study of international best practices, the Presidential Decree "On additional measures to further improve the vocational education system" was adopted in 2019 and introduced from the new academic year, industry qualifications frameworks, professional standards for professions and specialties, as well as differentiated educational programs.

While every country has its own unique features and traditions, there is much to be gained from looking at the practical lessons from international experience.

This article draws on a survey of practice to date in the design and implementation of NQFs highlighting both successful features of design and implementation and aspects which may now be considered mistakes. It does not advocate a 'single best way' for all countries because there is no approach which is universally applicable. Rather, it sets out key principles, explains the main issues that policy makers will need to consider, and reviews the advantages and disadvantages of the various ways of addressing these issues.

On 26-27 September, 2019 experts and professionals from the EU and Uzbekistan in Higher Education (HE) and Vocational Education \& Training meet in Tashkent to discuss Quality Assurance and Accreditation (QAA) and National Qualifications Frameworks (NQF).

The event was organized by the EU-funded programme Central Asia Education Platform (CAEP) in cooperation with the Ministry of Higher and Secondary Specialised Education of the Republic of Uzbekistan and the Delegation of the European Union to the Republic of Uzbekistan, and was part

January-February, 2021 
of a series of meetings organised in the region, with similar events already held in Kazakhstan, Kyrgyzstan and Tajikistan.

The aim of these meetings was to support the process of professionalization and modernization of education in the region by sharing EU expertise, facilitating policy dialogue at national level and exploring opportunities for development in the field in each country.

The first day focused on the topic of National Qualifications Frameworks (NQF), with participants discussing the current status of NQF development in Uzbekistan and representatives from Poland, Latvia and Romania sharing lessons learnt from the introduction of NQF in their respective countries. [3]

In the second day aimed on Quality Assurance and Accreditation (QAA) by considering the latest trends and challenges in the field and how both the Higher Education and Vocational Education \& Training sectors could work together to link Quality Assurance and Accreditation systems with the development of National Qualifications Frameworks. The two days were involved workshops and round table discussions on implementation of Quality Assurance and Accreditation and National Qualifications Frameworks in Uzbekistan along with recommendations for further actions. These reflections and suggestions were then feed into planned regional Peer Learning activities, in which representatives from Kazakhstan, Kyrgyzstan, Tajikistan, Turkmenistan and Uzbekistan will exchange developments and best practice in the sector.

A National Qualifications Framework is only a framework. It can play a vital role in supporting reforms but if it is not part of a wider strategy, it may achieve very little. There can be exaggerated and unrealistic impressions of what the building of an NQF can achieve in isolation from other developments. The key to successful NQF implementation is to develop a broad strategy that takes account of all factors influencing success. These include: policy coherence across different ministries, an enabling funding regime, support to education and training institutions including the development of learning materials and professional development. The most important thing is to develop genuine support and trust for the NQF among stakeholders. Employers' and workers' organizations have a key role to play in this process.

The process of developing a framework of qualifications must take into account the need to foster trust among the various stakeholders so that they can have confidence in the integrity of the resultant framework. It is vital to identify the stakeholders and advance consensus-building mechanisms in framework development through dialogue. An important way to build trust and acceptance is to ensure that any top-down approach is fused with a bottom-up process. It is possible to design different ways to consult but, in general, the approach should be as transparent as possible.

It's clearly seen from above mentioned that a NQF can help to address a number of the skills challenges; however, an NQF is not a quick solution to the many skills challenges faced by a country. Without clear objectives and an understanding of how an NQF can best be developed, implementation can be a lengthy and costly endeavor.

\section{References:}

1. https://www.ruecvet.uz/en/national-qualifications-framework-of-uzbekistan-is-approved

2. An Introductory Guide to National Qualifications Frameworks: Conceptual and Practical Issues for Policy Makers. 2007.

3. Работать ради лучшего будущего - Глобальная комиссия по вопросам будущего сферы труда Международное бюро труда - Женева: МБТ, 2019 г. 


\title{
DEVELOPMENT OF TOURISM POTENTIAL IN THE REPUBLIC OF UZBEKISTAN. TO EXAMINE THE EDUCATIONAL IMPACT CIRCLES OF TOURISM.
}

Gulistan state university student Islamova Dourdonakhon Rustamkhon kizi Islamovadurdona24@gmail.com +998990379729

\begin{abstract}
Annotation: The development of tourism potential in our country is increasing day by day. In particular, the extensive practical work carried out on the sphere, various activities, the exchange of experience with foreigners through direct active contacts, the formation of tour operators, the scale of turbochargers kengaytirishga actions are an obvious example of this. Measures for further improvement of various aspects of tourism, especially medical tourism, educational tourism, ecotourism, visiting tourism, have been developed, creating the basis for the improvement of the visiting places, the study of our national values and cultural heritage through the eyes of the world.
\end{abstract}

Keywords: Visit, tourism, education, medicine, ecotourism, history, hotel, domestic tourism, foreign tourism, foreigners, spirituality, income, national values, Highway, wellness.

Within the framework of the execution of the decree of the president of the Republic of Uzbekistan "on additional organizational measures to create favorable conditions for the development of tourism potential of the Republic of Uzbekistan"on February 3, 2018, various practical works were carried out in the cross-border regions with the aim of rapid development of domestic tourism, acquaintance of foreign tourists In particular, the District of Sirdarya is geographically convenient-as it is located on the banks of the Gokhna Saykhun River, natural opportunities for the development of Tourism and ecotourism are sufficient. Therefore, with the effective use of these opportunities by district entrepreneurs, the activity of "chehra turizm" LLC was launched. As a result, this business entity, specializing in the field of health care, family Rest in the field of tourism, was put into use. Most importantly, more than 30 new jobs have been created. 5 billion 500 million soums of credit funds of Commercial Bank were directed to the construction of this project, the total area of which is 2.5 hectares. At the first stage of the project, a 40-seat hotel, a 200 -seat indoor restaurant and a 200 -seat summer national cuisine restaurant were built. Also, the activities of camping and parking of cars, auto parts and shops of social and household items were launched so that drivers who went on a long journey could stop and rest. The main essence of the opportunities created is not only the net income entering the state budget through tourism, but also the increase in employment of the population, the emergence of new jobs, the rise in the sense of patriotism, the formation of a sense of pride, the creation of favorable opportunities for sharing experiences, the opening of unexplored aspects of our cultural heritage. On July 9-10, 2020, a meeting of the Tourism Council of the Commonwealth of Independent States was held in Samarkand. Representatives of hundreds of tourism sectors from such countries as Russia, Georgia, Azerbaijan, Armenia, Kazakhstan will participate. In general, tourism in Uzbekistan is slowly developing. One of the prospects of modern tourism is a unique natural habitat. The creation of all conditions for the transformation of such settlements into more picturesque meat, the organization of travelbop regions, the satisfaction of tourist needs are among the factors that constantly attract tourists. Uzbekistan is the most developed leading state of ecotourism in Central Asia. Our country is gaining the attention of tourists with its rich animal and vegetable world, unique landscape, national traditions and cuisine. Last year, 5 million 300 thousand tourists visited our country from more than fifty countries of the world and more than one billion 40 million dollars were invested in our treasury. In contrast to the existing factors of rapid development of the tourism industry, the establishment of new tourist services, the organization of pilgrimage tourism, the radical reform of educational tourism and, at the same time, the use of experience in the educational process should further serve our knowledge. In the process of communication with them regardless of the ethnic origin of the peoples, it is necessary to take into account their young characteristics and potential. This year's plan is to increase this number of tourists to 6 million and enrich my Treasury withizni 1 billion 300 million dollars. Decree of the president of the Republic of Uzbekistan "on measures for the further development of the tourism sector in the Republic of Uzbekistan"dated August 13, 2019 of the Honorable President of the Republic of Uzbekistan Shavkat Mirziyoyev was adopted, and this decree defines the organization of the tourism transport corridor "master of tourism" from the city of Khanabad of Andijan region to the in order to ensure the implementation of this decree, the cost of 
the project by the "Khol Khodji maskani" LLC in the direction of the M-34 "Tashkent-Dushanbe" highway passing through the Syrdarya region amounted to 35 billion manats. the cost of the project by "Davrbek nur" CJSC "in 15 km of the highway" Gulistan-Buka-Angren-Kokand-Andijan-Osh "a-373 M-39", providing services to the SOM population amounted to 1.1 billion manats. in order to develop the tourism sector, provide quality services to the population, the total value of 2 billion Manats was allocated by FLOWER GOLD TRADE LLC on the left side of the modern commercial complex and $15 \mathrm{~km}$ of the A-373 Highway. construction works are underway to provide services to modern vehicles worth som. According to the latest data from UNWTO (Butunjahan Tourism Organization), the tourism sector of Uzbekistan is ranked among the top 20 countries that are developing at the fastest pace. In particular, the tourism sector of our country is ranked fourth in the list of the fastest growing countries. The Independent publication was shared with an article about this. This list also includes the countries of Azerbaijan and Kazakhstan, which occupy 17 and 20 places.

\section{Used literature:}

1. Decree of the President of the Republic of Uzbekistan on February 3, 2018 "On creating favorable conditions for the development of tourism".

2. Decree of President Shavkat Mirziyoyev PU-5781 of August 13, 2019 "On measures for the further development of tourism in the Republic of Uzbekistan”. 


\title{
THE DEVELOPMENT OF THINKING AS A CONDITION FOR PERSONAL SELF- GOVERNMENT IN THE CONTEXT OF DISTANCE LEARNING
}

\author{
Z.K. Yusupova researcher \\ Samarkand State Institute of Foreign Languages
}

\begin{abstract}
Annotation: Taking as a basis the speech-thinking activity of the position of the verbalcommunicative function, realized on the basis of other higher system functions of a person-thinking and memory, and analyzing various approaches to their study, it can be determined that this activity is activated on the basis of solving communicative tasks, including the formulation of problem situations, solving speech problems, project methodology, business games. The development of this psycholinguistic factor, which is an important pedagogical condition for self-development, compensates for the lack of direct contact in distance learning.
\end{abstract}

Keywords: Thinking, memory, memorization, reproduction, thought, speech, knowledge.

Thinking can become an instrument of mediated reflection of reality in unity with the verbalcommunicative function. Communication is one of the types of activity, namely speech activity [1]. For example, in his work S. V. Kulikov [2], the text is considered as a three-plan education, in which three levels are distinguished:

a) the subject (denotational) level;

b) the semantic level;

c) the formal (verbal) level (its lexical-grammatical, phonetic / graphic design).

For the recipient, the subject is the semantic content of the perceived message. The product of the recipient's speech activity is the thought formed by him in the process of reception, which is adequately original to the thought of the communicator. We distinguish between thought as a structured process, in which a number of stages can be distinguished, and thought as a result, which is a complex mental formation, characterized, in particular, by the presence of a certain structure. The subject perceives the world through the prism of the need he experiences. At the first stage, the task solved by the subject in the course of understanding the reflected situation is to identify the element (the set of elements of the situation) that most meets the experienced need. The image of the situation is therefore different from its mirror image, expressed by the elements or a set of elements that are most significant from the point of view of the experienced need. The second stage of understanding a fragment of objective reality is the stage of developing the internal form of the subject plan. The object plan, endowed with an internal form that is relevant from the point of view of the need experienced by the subject, will represent the semantic plan of the formed thought. At the third stage, the subject develops a formal plan of the formed thought, i.e., fixes in consciousness the results of comprehension of the reflected fragment of objective reality with the help of certain formal means. The assumption that the function of such a formal tool is a unit of the universal subject code [3] is quite reasonable. As a result of connecting the schematic image of the reflected situation with the unit of the universal subject code, an internal word is formed. The inner word is a complete result of understanding the situation, in other words, it is actually a thought, understood as a result, and not as a process of understanding objective reality.

There is a strict sequence of motor, affective, figurative and verbal memory. The central place is given to the qualitative characterization of figurative and especially verbal memory as higher stages of memory development. If figurative memory is associated with imagination, then verbal memory is associated with thinking. P. P. Blonsky first pointed out the relationship between memory and thinking. In everyday life, he notes, memory and thinking often seem to be polar to each other. In reality, not only is memory the mainstay of thinking, but thinking, in turn, has a strong influence on memory and is its mainstay. Thinking, writes P. P. Blonsky, "actively participates in memorization, making every possible sense of the memorized material, discovering and establishing connections in it and comparing, controlling how well it is memorized" [5; P. 482].

According to the concept of P. P. Blonsky, the connection between memory and thinking is found in internal speech. Listening, we remember what we hear in the process of internal speech, as a result of which the thoughts we hear from the products of thinking, as they were originally, become objects of verbal memory in the future. Here thinking passes into memory. The reverse process - the transition of memory into thinking-is observed with a significant role of memory in the formation of concepts, as

January-February, 2021 
well as in the rudiments of reasoning thinking. A prominent role in the initial explanations and proofs is played by the reference to the example, i.e., the reference to the example. a simple recollection of what happened. Here is what P. P. Blonsky writes about this: "An empty head does not reason: the more experience and knowledge this head has, the more capable it is of reasoning» [5; p. 470].

In another aspect, the problem of memory is considered in the concept of L. S. Vygotsky [6]. The starting point for this concept is the general theory of the development of higher mental functions, put forward by L. S. Vygotsky and known as the cultural-historical theory of the development of the psyche. According to this theory, the essence of human memory consists in active memorization with the help of signs. At the initial stage of the development of cultural memory, the essence of the form of memorization is that a person introduces an artificial-object-stimulus into the situation, influencing the process of memorization (as well as subsequent reproduction). In the future, this object stimulus is replaced by a word, a verbal stimulus that plays the same role as a sign, a stimulus-a means. As a result, when memorizing, the child ceases to use external means of memorization, does not pay attention to them, and his reaction takes on a different character: the operation grows inside; from the external, which is carried out with mediating stimulus, it becomes the internal, which dispenses with these incentives.

The task of studying the problem of memory psychology is to "give a specific characteristic of mental activity in the conditions of memorization and thereby reveal the essential points of the content of memorization as a special type of activity" [7; p.330]. All this follows from the understanding of mental processes as an active reflection of objective reality, carried out in a specific human activity. Of interest to us is the conclusion that "only a combination of focus on memorization and high forms of intellectual activity really makes memorization the most productive" [4; p. 332].

The concept of memory includes a number of processes: memorization ("imprinting") and reproduction ("recognition"). Diverse memory processes can take different forms. So, the initial process of primary fixing of the material can to be committed in the form of involuntary imprinting, conscious, deliberate memorization, systematically organized memorization. The results of primary memorization can manifest themselves in the recognition of what a person has previously become familiar with when presenting it, and in its free reproduction. Reproduction can, in turn, be expressed in the form of representations and knowledge.

What is common to all these diverse mental processes is that they reflect or reproduce the past previously experienced by the individual. "Without memory, we would be creatures of the moment, our past would be dead to the future. The present, as it flows, would have irrevocably disappeared in the past" [8; p. 258].

\section{Bibliography:}

1. Gershunsky B. S. Computerization in the field of education: problems and prospects. - M.: Pedagogy, 1987. -263 p.

2. Kulikov S. V. The structure of thought as the subject of speech activity in the generation and perception of the text: Collection of scientific works of the M. Torez Moscow State Pedagogical Institute. - M., 1985. - Issue 243. - 187 p. - p. 9-19.

3. Zhinkin N. I. On code transitions in internal speech. // Questions

linguistics. -1964. - No. 6. - pp. 26-38.

4. Smirnov A. A. Problems of memory psychology. - M.: Enlightenment, 1966.

$422 \mathrm{p}$.

5. Blonsky P. P. Selected psychological works. - M.: "Enlightenment", 1964. - 547 p.

6. Vygotsky L. S. Thinking and speech. // In 2 vols. - M: Publishing House of the APN of the RSFSR, 1986. - Vol. 2. -360 p.

7. Simonova N. M. The experience of studying the nature of motivational orientations of students when learning a foreign language in high school / / . - M., 1980. - Issue 162. - 192 p.

8. Rubinstein S. L. Fundamentals of general psychology. - St. Petersburg: Peter Kom, 1999. - 705 p. 


\section{AGRICULTURAL SCIENCES}

\section{УДК 632.7.753}

\section{HARMFUL CICADAS DAMAGING COTTON}

Kozhevnikova A.G. Doctor of Biological Sciences, Professor of the Department of Plant Protection Tashkent State Agrarian University, Tashkent, Uzbekistan E-mail: gnadezhda03@gmail.com

Аннотация: The article presents data about researching cicadas, which damaging cotton and their morphological and biological characteristics, distribution, harmfulness, food connections and peculiarities of their diagnosis.

Ключевые слова: Cicadas, cotton, species composition, family, genus, species, diagnostics.

All the variety of natural conditions typical of Central Asia is represented in Uzbekistan. Under conditions of artificial irrigation, favorable conditions are created for the growing season of such thermophilic plants as cotton and others, provided that they develop one year.

It is known that protecting plants from pests from an economic point of view is much more effective than eradicating them, since plant pests after they have settled are difficult to eradicate.

Harmful organisms pose a constant threat to cotton.

In this regard, the main directions and tasks of our research in the field of plant protection were the development of methods for express diagnostics of pests, the development of natural resources of entomophages and the development of new biological products of plant protection based on the study of entomophages.

Many researchers $[1,2,3]$ note that in recent years have been expansion of habitats and increase harmfulness of various pests, such as cicadas, and other insects.

The material for this work was conducted for 10 years of research in Uzbekistan.

We use methods generally accepted in entomology and special method of Dubovskiy G.K. et al. [2]. Stationary and route collecting, observations, experiments and accounting were carried out.

Cicadas are insects with a piercing-sucking mouth apparatus, in addition to very short 3-segmented antennae with a terminal bristle and 3-segmented legs, they also differ in jumping hind legs and wing structure, they have not only longitudinal, but also transverse veins, and the anterior the pair is often denser than the back [4].

In Uzbekistan, cotton is damaged by Empoasca meridiana Zachv., Kyboasca bipunctata Osh., Austroagallia zachvatkini Vilb. [2,3] and two species of song cicadas Cicadatra ochreata (Mel.) and Cicadatra querula (Pall.) [5].

According to Yakhontov V.V. [5], the song cicada Cicadatra ochreata (Mel.) can be considered a serious cotton pest.

We noted damage by this cicada to cotton, sesame, potatoes, melons, mulberries, pears, poplar, grapevines and other crops [6].

According to Zakhvatkin A.A., in addition to the listed species, it harms cotton, alfalfa and cucumbers Asianidia asiatica Kusn. [6].

Results of the research show that three of the listed species are common and most harmful: Empoasca Meridiana Zachv., Kyboasca bipunctata Osh., Austroagallia zachvatkini Vilb.

Empoasca meridiana Zachv., Kyboasca bipunctata Osh., Austroagallia zachvatkini Vilb. polyphagous species.

Empoasca meridiana Zachv. Harmful to cotton, alfalfa, clover, beans, mung beets, potatoes, carrots, bell peppers, eggplants, zucchini, watermelons, melons, tomatoes, radishes, turnips and other agricultural plants. It feeds on pomegranate, grape, apple, peach and grape seedlings.

Feeding Kyboasca bipunctata Osh. in the Tashkent region we noted on cotton, alfalfa, beans, potatoes, and in the south of Uzbekistan - on cotton, alfalfa, beets, carrots and potatoes,

Austroagallia zachvatkini Vilb., Besides cotton, feeds on alfalfa, beans, beets, eggplants, cabbage

January-February, 2021 
and other agricultural plants.

Cicadatra ochreata (Mel.) and Cicadatra querula (Pall.) are found mainly in the south of Uzbekistan.

Our research on the study of cicadas as cotton pests in Uzbekistan showed that 6 species of cicadas damages cotton: Empoasca meridiana, Kyboasca bipunctata, Austroagallia zachvatkini, Cicadatra ochreata, Cicadatra querula and Asianidia asiatica.

\section{References}

1. Алимухамедов С.Н., Нарзикулов М.Н. Хлопчатник //Интегрированная защита растений. - «Колос». - Москва. - 1981. - С. 252.

2. Дубовский Г.К. Цикадовые (Auchenorrhyncha) Ферганской долины. - «Фан». - Ташкент: - 1966. - С. 116.

3. Митяев И.Д. Цикадовые Казахстана (Homoptera, Cicadinea). - «Наука». - Алма-Ата: 2001. - C.121.

4. Бей-Биенко Г.Я. Общая энтомология. - «Высшая школа». - Москва. - 1980. - С. 193.

5. Яхонтов В.В. Связь вредителей хлопчатника с сорной растительностью в Бухарском округе //Тр. Шерабудинской опытн. с.-х. станции. - Т. 1. - Ташкент: - 1928. - С. 15-16.

6. Кожевникова А.Г. Цикадовые (Auchenorrhyncha) - вредители хлопчатника в Узбекистане. Монография. - «Инновацион ривожланиш нашриёт-мабаа уйи». - Ташкент: - 2020. - С. 7 


\title{
DISTRIBUTION OF LOCUSTS IN THE COTTON FIELDS OF THE FERGANA VALLEY
}

\author{
Usmanov S. ${ }^{1}$, Begjanov M. ${ }^{2}$, Nurjanov A. ${ }^{3}$ \\ 1.Andijan Institute of Agriculture and Agrotechnology \\ 2.Karakalpak State University \\ 3.Institute of Zoology of the Academy of Sciences of Uzbekistan
}

The Fergana Valley is located on the east side of the Republic of Uzbekistan. The area of the Valley is on average 22 thousand square kilometers. The length of the territory $370 \mathrm{~km}$ from east to west and $150 \mathrm{~km}$ from south to north. Andijan, Namangan and Fergana regions of the Republic of Uzbekistan are located in the Fergana Valley. In addition, a small part of the Osh region of Kyrgyzstan and the Khojand region of the Republic of Tajikistan is located in the Fergana Valley. In the valley, cotton grows on 220,000 hectares and makes up the bulk of agricultural crops.

The research work was carried out to determine the density and species composition of locusts widespread in the cotton field in 2018-2019. The experiments were provided in Pap district of Namangan region (table 1) and Kuva district of Fergana region (table 2). According to the results of the experiments carried out in the cotton field of Pap district of Namangan region, 15 species of locusts were distributed. The locust species as Acrotylus insubricus Scop., 1786. and Pyrgomorpha bispinosa deserti B.-Bien. \& Mistsh., 1951. were found in $10.9 \%$ each, Dociostaurus maroccanus (Thunb., 1815.) in 9.5\% and Calliptamus italicus italicus (Lin., 1758.) in 21.1\%. These species have been identified as dominant species in cotton fields.

The number and species composition of locusts in the cotton field.

Table 1. (Pap district of Namangan region, 07.07.2018 y., specimens per hour).

\begin{tabular}{|c|c|c|c|c|c|c|}
\hline \multirow{3}{*}{$\mathrm{N}$} & \multirow{3}{*}{ Species } & \multicolumn{5}{|c|}{ Number } \\
\hline & & \multicolumn{2}{|c|}{ Imago } & \multirow{2}{*}{ Nymph } & \multirow{2}{*}{ Total } & \multirow{2}{*}{$\%$} \\
\hline & & q & $\hat{0}$ & & & \\
\hline 1 & Acrotylus insubricus Scop., 1786. & 8 & 7 & 1 & 16 & 10,9 \\
\hline 2 & Locusta migratoria Lin., 1758. & 1 & & & 1 & 0,7 \\
\hline 3 & Pyrgomorpha bispinosa deserti B.-Bien. \& Mistsh., 1951. & 9 & 7 & & 16 & 10,9 \\
\hline 4 & Calliptamus italicus italicus (Lin., 1758.) & 15 & 13 & 3 & 31 & 21,1 \\
\hline 5 & Calliptamus turanicus Tarb., 1930. & 7 & 6 & & 13 & 8,8 \\
\hline 6 & Acrida oxycephala (Pall., 1771.) & 2 & 1 & 5 & 8 & 5,4 \\
\hline 7 & Truxalis eximia Eichw., 1930. & & & 6 & 6 & 4,1 \\
\hline 8 & Oedipoda miniata (Pall., 1771.) & 8 & 5 & & 13 & 8,8 \\
\hline 9 & Oedipoda caerulescens (Lin., 1758.) & 4 & 7 & & 11 & 7,5 \\
\hline 10 & Sphingoderus carinatus (Sauss. 1888.) & 2 & 3 & & 5 & 3,4 \\
\hline 11 & Ramburiella foveolata (Tarb. 1931.) & 1 & 1 & & 2 & 1,4 \\
\hline 12 & Duroniella kalmyka (Adel., 1906.) & 3 & 2 & & 5 & 3,4 \\
\hline 13 & Tetrix subulata (Lin., 1758.) & 1 & 2 & & 3 & 2,0 \\
\hline 14 & Tetrix tartara tartara (Sauss., 1887.) & 3 & & & 3 & 2,0 \\
\hline 15 & Dociostaurus maroccanus (Thunb., 1815.) & 6 & 8 & & 14 & 9,5 \\
\hline & Total: & 82 & 67 & 15 & 164 & 100 \\
\hline
\end{tabular}

The following experiments to determine the density and species composition of locusts in a cotton field were carried out in September 2018 in the Kuva district of the Fergana region (Table 2). According to the results of the experiment, the species Calliptamus italicus italicus (Lin., 1758.) is dominating in the amount of 33 specimens per hour. This number consists of 29,2\% of the new share of all locusts distributed in the cotton field. In addition, the number of other locust species has been determined. Species as Aiolopus thalassinus thalassinus (Fabr., 1781.) and Locusta migratoria Lin., 1758. accounted for 16,8 \%, Pyrgomorpha bispinosa deserti B.-Bien. Mistsh., 1951. 20,4\%, and the 
number of the Moroccan locust (Dociostaurus maroccanus (Thunb., 1815.)) was 7,9 \% of the total number of locusts spread in the cotton field (Table 2)

The number and species composition of locusts in the cotton field.

Table 2.

(Kuva district of Fargana region, 09.09.2018 y., specimen per hour).

\begin{tabular}{|c|c|c|c|c|c|c|}
\hline \multirow[t]{3}{*}{ № } & \multirow[t]{3}{*}{ Species } & \multicolumn{5}{|c|}{ Number } \\
\hline & & \multicolumn{2}{|c|}{ Imago } & \multirow{2}{*}{ Nymph } & \multirow{2}{*}{ Total } & \multirow{2}{*}{$\%$} \\
\hline & & q & $\hat{\sigma}$ & & & \\
\hline 1 & Aiolopus oxianus Uv., B.P., 1926. & 2 & 3 & 0 & 5 & 4,4 \\
\hline 2 & A. thalassinus thalassinus (Fabr., 1781.) & 12 & 7 & 0 & 19 & 16,8 \\
\hline 3 & Duroniella gracilis Uva., 1926. & 4 & 2 & 0 & 6 & 5,3 \\
\hline 4 & Acrida oxycephala (Pall., 1771.) & 0 & 0 & 3 & 3 & 2,7 \\
\hline 5 & Pyrgomorpha bispinosa deserti B.-Bien. \& Mistsh., 1951. & 11 & 8 & 4 & 23 & 20,4 \\
\hline 6 & Locusta migratoria Lin., 1758. & 11 & 8 & 0 & 19 & 16,8 \\
\hline 7 & Sphingoderus carinatus (Sauss. 1888.) & 3 & 2 & 0 & 5 & 4,4 \\
\hline 8 & Calliptamus italicus italicus (Lin., 1758.) & 19 & 14 & 0 & 33 & 29,2 \\
\hline & Total: & 62 & 44 & 7 & 113 & 100 \\
\hline
\end{tabular}

The results of the experiments showed that 18 locust species are widespread in the cotton field of the Fergana Valley. Among them, 6 species were found as a dominant species with a density of 8-32 specimen per hour. Among the dominant locust species, the swarming locusts were identified as Moroccan, Italian and Asian locusts in a non-gregarious form. Such a number of swarming locusts in a cotton field, even their level of economic threshold is not high, they are considered dangerous because Imago in such number can put a lots of egg-pods and can make a swarm at the next year.

According to the monitoring of the area, no egg-pods of gregarious locusts were found. Based on the data obtained, it can make conclusion that, near the cotton field, there are natural foci of reproduction of swarming locusts such as Italian and Moroccan locusts. 


\section{TECHNICAL SCIENCE}

\section{OBTAINING A FILTER MATERIAL BASED ON BASALT FIBER USED FOR THE OIL INDUSTRY}

\section{E. Egamberdiev, Yo.Ergashev, G.Rakhmanberdiev el.0919@mail.ru Tashkent Institute of Chemical Technology}

Key words: Cellulose from topinabour, cellulose from cotton linters, basalt fiber, strength, composite filter paper, fiber hydration, filler.

Composite filter paper obtained on the bases of cellulose from topinambour, cotton linters of cellulose and basalt fiber. The composition and properties mineral filler, which were used in the preparation of filter paper were studied. The results obtained are shown in graphical form.

Introduction. At present, there are about 650 types of paper for different purposes worldwide. Among them, cardboard and paper are produced from mineral raw materials. As you know, products for various purposes of construction and national economy are manufactured on the bases of mineral raw materials. The technology of manufacturing fiber and various products from mineral products is reflected poorly in technical literature. Our goal is to overcome these shortcomings. Researches in this area are mainly conducted in China, Russia and Ukraine.

Numerous studies have been carried out on the creation of a method for obtaining fibers from basalt, including mineral raw materials. Researchers developed an uninterrupted method of producing fibers from basalt in the 1960s. Research works have been carried out to improve technology and equipment. These works were carried out in the 80 s of the last century. In the late of 90 's, the factory was built. However, this technology required a lot of energy. Basalt fiber was for military purposes, but the cost was not paid much. By 2000, the technology of basalt fiber production and basic equipment was improved, resulting in lower product costs, and the number of customers expanded. In 2000-2002, products manufactured by the factories were started to be used widely in the automobile industry.

The first factory to produce basalt fiber was built in China. The energy consumption of the new technology has dropped dramatically: it cuts its natural gas consumption by three times, and electricity is five times lower. Chengdu company "Chengdu Aerospace Tuohim Science \& Technology Co., LTD" and the company "Chandu and Shanghai Russia Gold Basalt Fiber" in Shanghai have launched the production based on the technology and modular equipment developed by Chinese S.P.Osnos.

Currently, Chandu company produces about 1800-2000 tonnes of basalt fiber per year. The company in Shanghai is 2000 tons per year. In Russia, based on the TE VSG 2000 technology line, NPO began production of "Vulkan". Its capacity is 1800-2000 tons per year.

As you know, basaltic fibers are resistant to chemicals. It preserves 90-98\% mass under the influence of $0.5-2 \mathrm{n}$ sodium hydroxide solution, and in $2 \mathrm{n}$ chloride acid - 50-70\%. In addition, basaltic fibers are resistant to high temperatures $(300-700 \mathrm{oC})$. These properties of basaltic fibers allow to use as a filter material for the production of products with acidic and alkaline state and for wastewater treatment.

Basalt fiber filters are widely used in the filtration of the dusty air with a working temperature of 300-650oC emitting from metallurgical and chemical enterprises. Filter materials made of $17-$ $25 \mu \mathrm{m}$ of diameter of basalt fibers are sufficiently durable, waterproof, robust and elastic. In the manufacture of wine and cognac, fine-fiber sulphide cellulose (bleached), asbestos-fiber filters are used. Depending on the amount of asbestos added to the cellulose, the filter materials will be of different markers: YK-1, YK-2 and YK-3. The appropriate branded filter is selected depending on the filter mass concentration. For example, YK-3 is used for filtering a medium viscosity strong and diserted wine.

Methodical part. To obtain a filter material, the composition should be prepared before. Preparation of samples is carried out on LA-3 paper-molding device. The machine is prepared prior to sampling. After that, the paper-molding process is started. The prepared paper mass is mixed. Designed for $1 \mathrm{~m} 2$ of paper weighing is taken from the calculated mass. The surface of the paper-molding device 
is $0.0314 \mathrm{~m} 2$. If the weight of $1 \mathrm{~m} 2$ of the sample of paper to be extracted is $60 \mathrm{~g}$, then absolute dry fiber (when the finished paper has a moisture content of 7\%) will need to g. Before filling the paper, wet the net and position it properly.

Then the water is poured into the forming chamber up to 71 at first and then 81 . The suspension is slowly mixed not touching the walls of device and a web without generating foam. Then the tap is opened and water goes out from the molding device. Here, the fibrous layer begins to sink on the surface of net. The remaining water in the suction chamber is absorbed by vacuum pumping when 2 liters of water is left in the molding chamber. After absorbing fluid from the molding chamber, the fiber layer formed on the net is further dehydrated for $10 \mathrm{sec}$. The net sieve is dried over the drying chamber. Dried paper samples are weighed on technical scales.

Experimental part. Taking into account the above points, we have identified the goals of our research. Initially, the experimental conditions and quantities of raw materials contained in composition were determined and their resistance to alkali and acid activity was studied. (Table-1)

The loss of mass under the influence of chemical solutions on the basalt fibers, $\%$

\begin{tabular}{|c|c|c|c|c|}
\hline Basalt fiber samples & $\mathrm{H}_{2} \mathrm{O}$ & $0.5 \mathrm{n} \mathrm{NaOH}$ & $2 \mathrm{n} \mathrm{NaOH}$ & $2 \mathrm{n} \mathrm{HCl}$ \\
\hline № 1 & 99.63 & 98.3 & 92.8 & 76.9 \\
\hline № 2 & 99.7 & 98.9 & 90.7 & 49.9 \\
\hline № 3 & 99.6 & 94.6 & 83.3 & 38.8 \\
\hline
\end{tabular}

Table 1 shows that basaltic fibers are very resistant to alkaline solution. It has been concluded that this property of basaltic fibers can be used as a filter material for cleaning industrial wastewater and municipal sewage. In the next step, the thermal resistance of the selected basaltic fibers was examined and the results were analyzed. Table- 2 shows the thermal resistance of the basaltic fibers.

Comparative thermal resistance of basalt fibers at different temperatue, $\%$

\begin{tabular}{|c|c|c|c|c|c|}
\hline Temperature, ${ }^{\circ} \mathrm{C}$. & 300 & 400 & 500 & 600 & 700 \\
\hline Initial comparative resistance & \multicolumn{5}{|c|}{100} \\
\hline № $1234, \mathrm{~kg} / \mathrm{mm}^{2}$ & 98.7 & 88.7 & 58.9 & 38.4 & 25.0 \\
\hline № $2240, \mathrm{~kg} / \mathrm{mm}^{2}$ & 99.0 & 89.0 & 61.0 & 39.0 & 27.0 \\
\hline № $3254, \mathrm{~kg} / \mathrm{mm}^{2}$ & 100 & 90.0 & 65.0 & 38.8 & 28.6 \\
\hline
\end{tabular}

As can be seen from the table, the material prepared from basalt fibers can also be used at $600^{\circ} \mathrm{C}$. We selected two types of fiber for the next research. Filter materials were obtained using 2 types of basalt fiber (ultra and tough fibers). In the next table a number of samples of cotton lint cellulose and basalt fiber composition were examined.

Table-3

Quality indexes of filter materials produced from the composition of basalt fibers and cotton lint cellulose

\begin{tabular}{|c|c|c|c|c|c|c|}
\hline № & $\begin{array}{c}\text { Amount of samples and } \\
\text { types }\end{array}$ & Rough , $\mathrm{ml} / \mathrm{min}$ & $\begin{array}{l}\text { Porosity, } \\
\mathrm{ml} / \mathrm{min}\end{array}$ & $\begin{array}{c}\text { Ash content } \\
\%\end{array}$ & $\begin{array}{l}\text { Breakage } \\
\text { length, } \mathrm{km}\end{array}$ & $\begin{array}{c}\text { Tearing resistance in } \\
\text { dry state, } \mathrm{H}\end{array}$ \\
\hline 1 & Cotton lint, $84 \mathrm{~g} / \mathrm{m}^{2}$ & $321-468$ & $204-206$ & 0.257 & 3502 & $42.0-44.57$ \\
\hline 1 & $\begin{array}{l}\text { Ultra-typed basalt fiber, } 81 \mathrm{~g} / \\
\mathrm{m}^{2} 20 / 80\end{array}$ & 730 & 478 & 16.24 & 1806 & 23.57 \\
\hline 2 & $\begin{array}{l}\text { Ultra-typed basalt fiber, } 81 \mathrm{~g} / \\
\mathrm{m}^{2} 40 / 60\end{array}$ & 762 & 480 & 15.88 & 1900 & 24.60 \\
\hline 3 & $\begin{array}{l}\text { Ultra-typed basalt fiber, } 81 \mathrm{~g} / \\
\mathrm{m}^{2} 60 / 40\end{array}$ & 803 & 482 & 13.12 & 2004 & 26.89 \\
\hline 4 & $\begin{array}{l}\text { Ultra-typed basalt fiber, } 81 \mathrm{~g} / \\
\mathrm{m}^{2} 80 / 20\end{array}$ & 837 & 484 & 12.17 & 2202 & 28.94 \\
\hline 1 & $\begin{array}{c}\text { Tough-typed basalt fiber, } \\
76,8 \mathrm{~g} / \mathrm{m}^{2} 20 / 80\end{array}$ & 637 & 410 & 19.46 & 2200 & 29.20 \\
\hline 2 & $\begin{array}{c}\text { Tough-typed basalt fiber, } \\
76,8 \mathrm{~g} / \mathrm{m}^{2} 40 / 60\end{array}$ & 670 & 412 & 17.9 & 2360 & 29.87 \\
\hline 3 & $\begin{array}{c}\text { Tough-typed basalt fiber, } \\
76,8 \mathrm{~g} / \mathrm{m}^{2} 60 / 40\end{array}$ & 701 & 413 & 16.54 & 2525 & 30.16 \\
\hline 4 & $\begin{array}{c}\text { Tough-typed basalt fiber, } \\
76,8 \mathrm{~g} / \mathrm{m}^{2} 80 / 20\end{array}$ & 721 & 415 & 14.7 & 2696 & 30.77 \\
\hline
\end{tabular}


Conclusion.Year by year the demand of ecologists is growing. Industrial enterprises and municipalities should reduce pollutants. One of the main ways in which environmentalists can address this problem is by reducing the discharge of the atmosphere and water into the filter. The best way to do this is to use a basalt fiber filter. This material is very resistant to chemicals (salt, acids and alkalis) and can be used for a long time. In addition, there are different compositions of filters produced from basalt fibers, which can be used for purifying gases emitting from metalworking plants with $800 \mathrm{oC}$ waste, chemical plants, construction materials manufacture and energetics. Thus, the basaltic fiber filter can be used to purify the air at the state with working temperature of $300-650 \mathrm{oC}$.

\section{References}

1. E. Egamberdiev, G. Rakhmanberdiev, A.Mardonov "Study of the sorption rate of composition paper samples obtained on the bases of cellulose-bearing plants cellulose and basalt fiber" Austrian Journal of Technical and Natural Sciences 1-2, 2018.56-62p

2. G.R.Rakhmanberdiev, E.A.Egamberdie, A.I. Gordeeva "Possibility of using basalt fiber to obtain paper with increased strength", "Composition materialar" Scientific-technical and practical journal, amaliy2, 2014, pages 84-86. 


\section{RESEARCH POSSIBILITY OF REPEAT THE USE OF WASHED WATER IN THE PRODUCTION OF COTTON CELLULOSE}

Doctor of Technical Sciences, prof.

R. Saifutdinov, K. D. Mirsaidova

mt (97) 699-06-42, e-mail mail say-ram@mail.ru

Tashkent Chemical-Technological Institute

Department of Industrial Ecology

The problem of environmental protection is given exceptionally great attention in our country. In recent years, this issue has been deeply reflected in the Constitution of the Republic of Uzbekistan and in the fundamental laws on land, its subsoil, waters, forests, atmospheric air and fauna, as well as in special decrees on nature protection of the Oliy Majilis and the Cabinet of Ministers of the Republic of Uzbekistan [1,2].

The strategy was developed following the results of a comprehensive study of issues relevant and significant for the population and entrepreneurs, analysis of legislation, law enforcement practice and foreign experience. The document was published on global Internet networks and was widely discussed with the participation of experts and the public. [2]

Currently, in the field of the pulp and paper industry (PPI) of the Republic of Uzbekistan, it is required to create new technological processes that ensure a decrease in water consumption, a decrease in the amount and toxicity of wastewater, gas emissions, allowing to organize closed cycles of water use and regeneration of chemicals, which are one of the the most important areas of scientific and technological progress.

Based on the above, the goal of this work is to develop a technology for producing cotton cellulose from low-grade linters of the 2 nd grade B type of medium weediness with a minimum consumption of water and chemicals, which contributes to environmental protection.

The object of the study was the cooking liquor, waste liquor, sodium hypochlorite, the consumption of washing water, their purification after washing, and the quality indicators of the obtained cotton cellulose.

Under laboratory conditions, cotton cellulose was obtained by alkaline cooking under the following conditions: Mass concentration $-10 \%, \mathrm{NaOH}$ consumption $-2 \%, \mathrm{NaClO}-0.25 \%$, cooking temperature $-140^{\circ} \mathrm{C}$, duration - $180 \mathrm{~min}$.

After alkaline cooking, the pulp was squeezed out, while in the pulp there was spent liquor with a mass 2 times higher than the mass of the feedstock.

The first series of experiments were aimed at studying the sanitary characteristics of the spent liquor, the flow rate of rinsing water, and the study of the physicochemical properties of the resulting cellulose.

Waste liquor is a seemingly dark brown liquid containing organic and inorganic substances. A dark brown color to the spent liquor is given by the lignin contained in the solution, although it is absent in the cotton fiber, it enters the lint through the lignin containing natural satellites, such as leaves, seeds and other parts of cotton.

Inorganic weeds of linters include dust, sand and others that get into the fiber during the collection and transportation of raw cotton.

The cotton cellulose was washed with separate portions of distilled water.

It has been experimentally established that after alkaline cooking for washing one volume of cellulose mass to a neutral medium, 4-6 equal volumes of pure water are consumed, depending on the degree of weediness of the linters. Therefore, the main indicators of the quality of lint include, along with its maturity, also weediness.

The spent liquor and each individual batch of cotton pulp wash water were sent to research to determine their water consumption and sanitation characteristics.

After bleaching with sodium hypochlorite sodium hypochlorite, the optimal flow rate of bleaching of the spent liquor and rinsing water was experimentally determined, the decrease in the $\mathrm{pH}$ of the medium was studied, the residual amount of sodium hydroxide was determined, and the chemical oxygen demand (COD5) and biochemical oxygen demand (BOD5) of the spent liquor and consumption were determined. flushing water.

The results of the study of physical and chemical indicators, sanitary characteristics of the spent liquor and wash water are presented in Table 1. 
Table 1

Physicochemical indicators and sanitary characteristics of spent liquor, cooking solutions and rinsing water

\begin{tabular}{|c|c|c|c|c|c|c|c|}
\hline № & Test solution & $\begin{array}{c}\text { Optical density } \\
\text { before bleaching }\end{array}$ & $\begin{array}{c}\text { Optical density } \\
\text { after } \\
\text { discoloration } \\
\text { wash water with } \\
\text { NaClO } \\
\text { Wednesday }\end{array}$ & $\begin{array}{c}\text { The remainder } \\
\text { before } \\
\text { NaOH, } \\
\%\end{array}$ & $\begin{array}{c}\text { COD }_{5}, \\
\mathrm{mg.O}_{2}\end{array}$ & $\begin{array}{c}\text { BOD }_{5}, \\
\mathrm{mg.O}^{\prime}\end{array}$ \\
\hline 1 & $\begin{array}{c}\text { Spent liquor after } \\
\text { the bottom hole }\end{array}$ & 2,9 & 2,7 & 12,4 & 1,5 & 1351,50 & 260,00 \\
\hline 2 & $\begin{array}{c}\text { Solution after the } \\
\text { first wash }\end{array}$ & 0,88 & 0,09 & 11,1 & 0,9 & 751,95 & 117,34 \\
\hline 3 & $\begin{array}{c}\text { Solution after the } \\
\text { second washing }\end{array}$ & 0,25 & 0,04 & 9 & 0,72 & 258,15 & 38,6 \\
\hline 4 & $\begin{array}{c}\text { Solution after the } \\
\text { third washing }\end{array}$ & 0,06 & 0,025 & 6,9 & 0,16 & 108.12 & 21,50 \\
\hline
\end{tabular}

As follows from table 1. The washings after the first, second and third washings were discolored at insignificant consumption of sodium hypochlorite. Optical density after decolorizing solutions fully meet the requirements for water for boiling cotton linters.

It is easy to reduce the optical density of the wash water using sodium hypochlorite, but this effect is not observed when the waste liquor is decolorized. This is due to the presence in the waste liquor of a large amount of dissolved organic and inorganic impurities, which create difficulties in its bleaching. By increasing the consumption of sodium hypochlorite, it was possible to reduce the optical density of the spent liquor from 2.9 to 0.06 .

Washing the pulp after alkaline cooking contributes to a sharp decrease in the optical density of the washing solutions. In particular, when comparing the wash solution after the second wash with the clean solution, there was practically no visual difference in optical density.
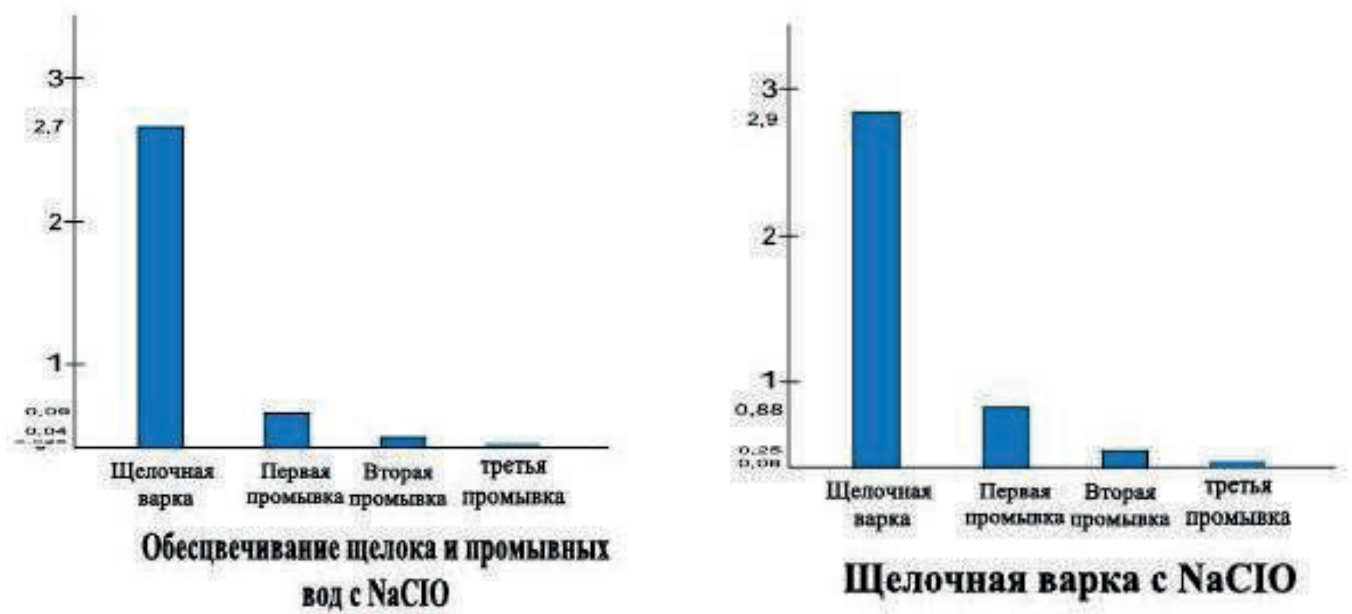

Щелочная варка с $\mathrm{NaCIO}$

The content of residual sodium hydroxide also decreases with an increase in the number of washes. With each subsequent washing in the washing water, the $\mathrm{pH}$ of the solution medium, the optical density and the content of residual sodium hydroxide decrease.

As follows from the above data, after alkaline cooking of cotton linters, the amount of $\mathrm{NaOH}$ decreased from $2 \%$ to $1.5 \%$, the optical density was 2.9 to 0.88 , and when $\mathrm{NaClO}$ was added to the cooking mass, it was $2.7-0.09$.

After the first wash, the wash water had an optical density of 0.88 , and after the third wash, 0.06. That shows the restoration of sanitary standards of water, which allows it to be used in the preparation of cooking solutions in the next stages of alkaline cooking.

The purified water can also be used in the first wash of the pulp.

The graph shows the results of determining the remaining $\mathrm{NaOH}$ after each wash rate. Washing 
of cotton pulp after alkaline cooking to a neutral medium was observed with 5 times washing of the pulp.

\section{Findings}

1. The possibility of obtaining cotton cellulose from lint of 2 grades B types by medium alkaline cooking with the addition of sodium hypochlorite has been investigated.

2. Restoration of sanitary standards of water, allows it to be used in the preparation of cooking solutions in the next stages of alkaline cooking, purified water can also be used in the first and second washing of the pulp.

3..Based on calculations of laboratory data, it is shown that the purified water can be reused without reducing the quality of the product obtained. This allows rinsing water to be returned to the pulp and paper industry, where a multiple reduction in water consumption can be achieved.

4. The developed technology for the production of cotton cellulose contributes to the conservation of material resources, in addition, the reduction of harmful emissions on the environment is achieved.

\section{List of used literatures:}

1.Decree of the President of the Republic of Uzbekistan Sh.M. Mirziyoyev dated February 7, 2017 No. UP-4947 "On the strategy of actions in five priority areas of development of the Republic of Uzbekistan in 2017-2021."

2. Copyright certificate No. 267329 - Method for bleaching cellulose. Nikitin V.M., Akim G.L. Published in BI 1970, No. 12.

3. Inventor's certificate No. 910899 Sayfutdinov R., Mirkamilov TM, Akim GL, Method of producing cotton cellulose. Publ. 03/05/82 in BI number 9.

4. Sayfutdinov R.S. Development of a chemical technology for the use of cotton waste for the production of chipboard and cellulose. Abstract of a thesis in technical sciences. Tashkent, 1998, p. 49 . 
CALCULATION OF IMPACT EFFECTS ON COTTON FLY UNDER EXISTING HORIZONTAL CLEANING TECHNOLOGY

\title{
Sobirov Ilxom Khaxramanovich, Usmanov Xayrulla Saydullaevich, Khaitbaev Khursand Khushnudovich,
}

\begin{abstract}
The article contains materials on the analysis of the work of existing raw cotton cleaners and revealed the shortcomings of horizontal cotton cleaning technology. Calculations were made of force effects on cotton fly under the technology of horizontal method of cleaning from fine weed impurities.
\end{abstract}

Key words: cotton cleaning, cotton-cleaning unit, trash impurities, peel drum, mesh surface.

Introduction. Previous studies [1; -c.24] confirm the need to continue research in the field of raw cotton cleaning. It was revealed that the loss of pulp during cotton cleaning is $0.08 \%$ to $0.85 \%$ of the weight of weeds released after the CCS flow line, depending on the storage modes of raw cotton and the initial quality indicators of raw cotton (Fig. 1). Based on the average cotton treatment plant harvesting 30,000 tons per year, this figure varies from 240 tons to 255 tons of cotton fiber.

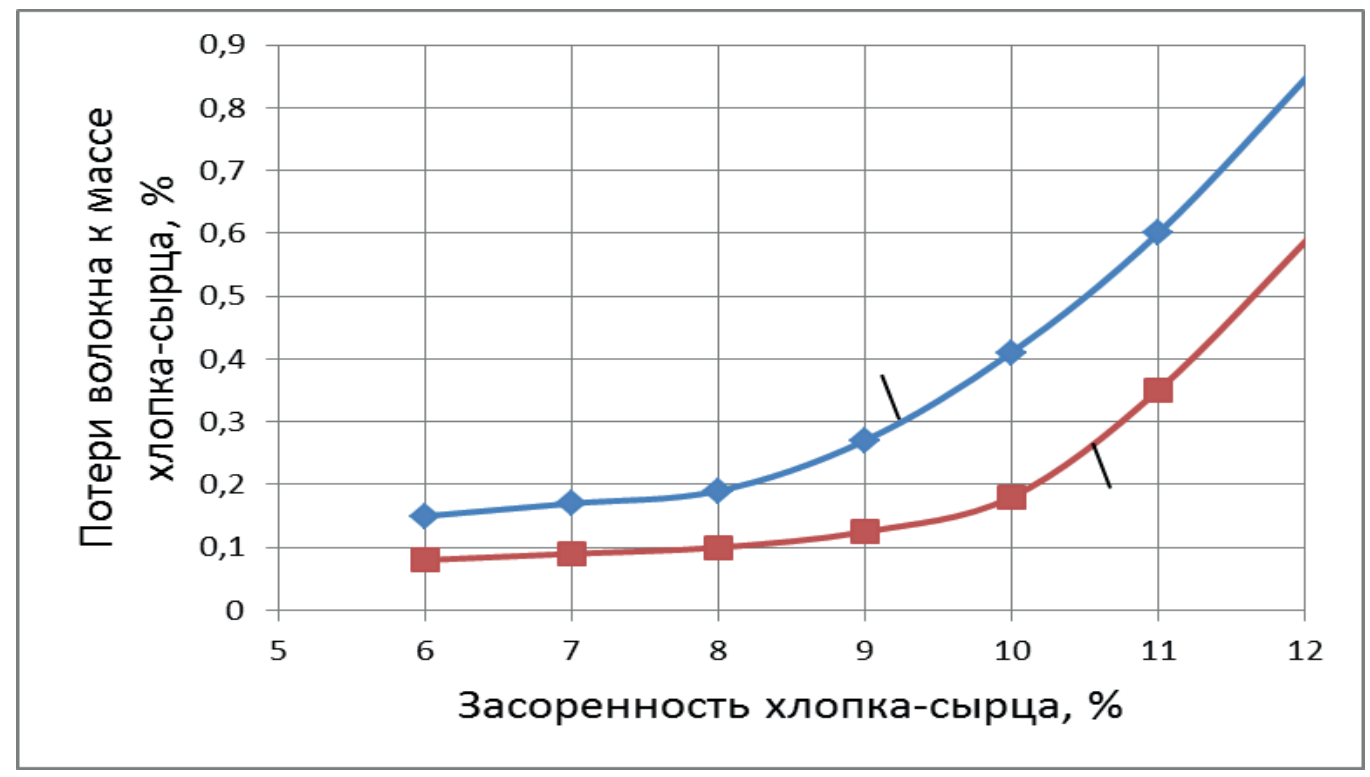

1-without storage; 2-with storage.

Fig.1 Dependencies of loss of pulp with weed impurities during cleaning (to the weight of raw cotton) on clogging

The cotton cleaning plants and cotton-textile clusters currently operate serial eight-drum cleaners of SCh-02 grades, 1XK and pile blocks of EN.178 grade as part of the UHK production line [2], developed in the 80 s of the last century.

The theoretical description of the mechanism for separating fine particulate impurities from fibrous material is laborious, since it is not possible to accurately determine the adhesion force of particulate impurities to fibrous material in its various layers. Also, the trajectory of raw cotton and weed impurities during cleaning are not sufficiently fundamentally studied, applied models have not been created that describe effective methods of cleaning raw cotton from fine weed impurities. Further theoretical research in these areas, in our opinion, is relevant [3; - p.64-65].

Research results. On cleaning machines, 1XK cleaning sections work inefficiently, since the working contact angle of the pile drum and the mesh surface is $100^{\circ}$ (Fig. 1). 

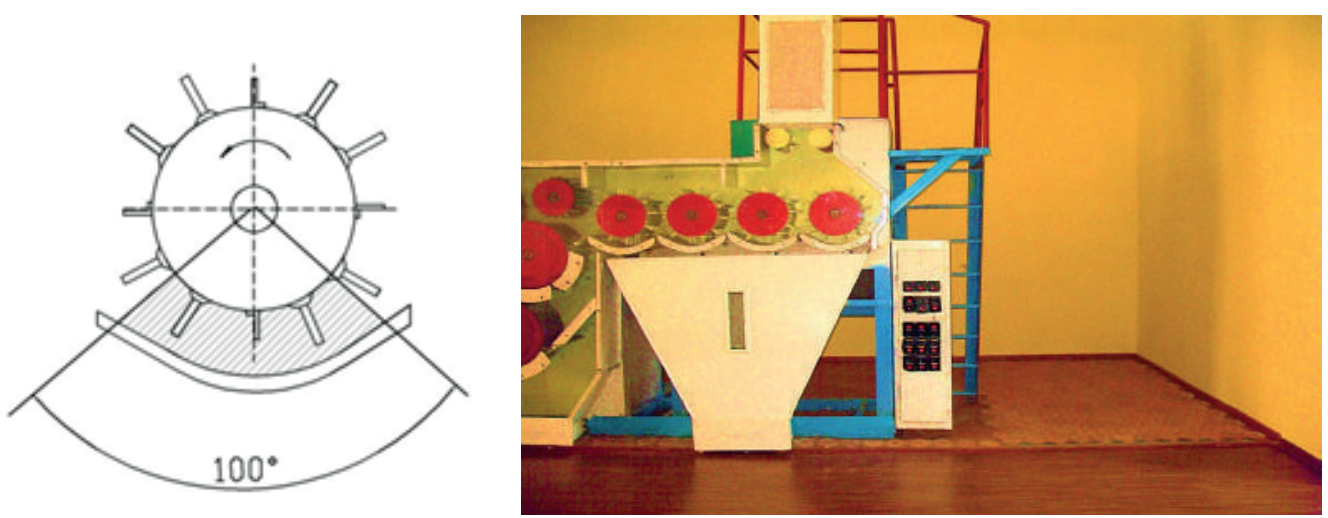

Pic. 1 Diagram of the construction of the pile drum and the mesh surface in existing cleaning structures $1 \mathrm{XK}$.

In addition, in the area of raw cotton transportation from one drum to another, significant damage occurs to raw cotton (especially in low grade processing) due to a sharp change in the direction of movement of raw cotton in the next cleaning section during the process. In order to study the effect of forces in the zone "pile drum-fly-net surface" on the natural quality indicators of processed raw cotton during horizontal movement of cleaned raw cotton, we carried out the following calculations. As the pile drum rotates, the raw cotton fly moves along the mesh surface, resulting in a centrifugal force $[4 ;$-c. $60-63]$.

In the opposite direction to the rotation of the pile drum, the force of friction of the fly against the mesh surface acts.

The rotation speed of the pile drum is $450 \mathrm{rpm}$. The axial distance between the two drums is $d=420 \mathrm{~mm}$, the radius of the drum is $R=200 \mathrm{~mm}$, the height of the bars is $l=50 \mathrm{~mm}$ and the mass of one fly is taken as g.

According to the second law of Newton the received acceleration of a short meeting in direct ratio to the applied force $F=m a$ and in inverse proportion to her weight $[\mathrm{F}]=\mathrm{kgm} / \mathrm{s} 2$.

We assume that the fly moves evenly along the mesh surface, and then we determine the forces acting on it (Figure 2).

We calculate the force acting on the fly with a mass of $m=6 \mathrm{~g}$ from the side of the pile drum with a radius of $R$ [5; - p. 10742 - 10747].

For calculations, we denote the speed of $v$ rotation of the bevel drums through, the radius of the $R$ drum, the linear speed of $v$ the bevel drum, which is determined by the following formula.

$$
v=2 \pi v R \quad \vartheta=2 \pi v R
$$

It is known that the rotation speed of the pile drum is:

$$
v=420 \text { об } / \text { мин }=420 о б / \text { мин }=7,0 о б / \text { мин }
$$

From here we find the linear rotation speed of the pile drum

$$
v=2 \cdot 3,14 \cdot 7,0 \cdot 0,20=8,792 \mathrm{M} / \mathrm{ce \kappa}
$$

The fly of the raw cotton $m$ mass is influenced by the force from the side of the pile drum and the friction force between the fly and the mesh surface. 


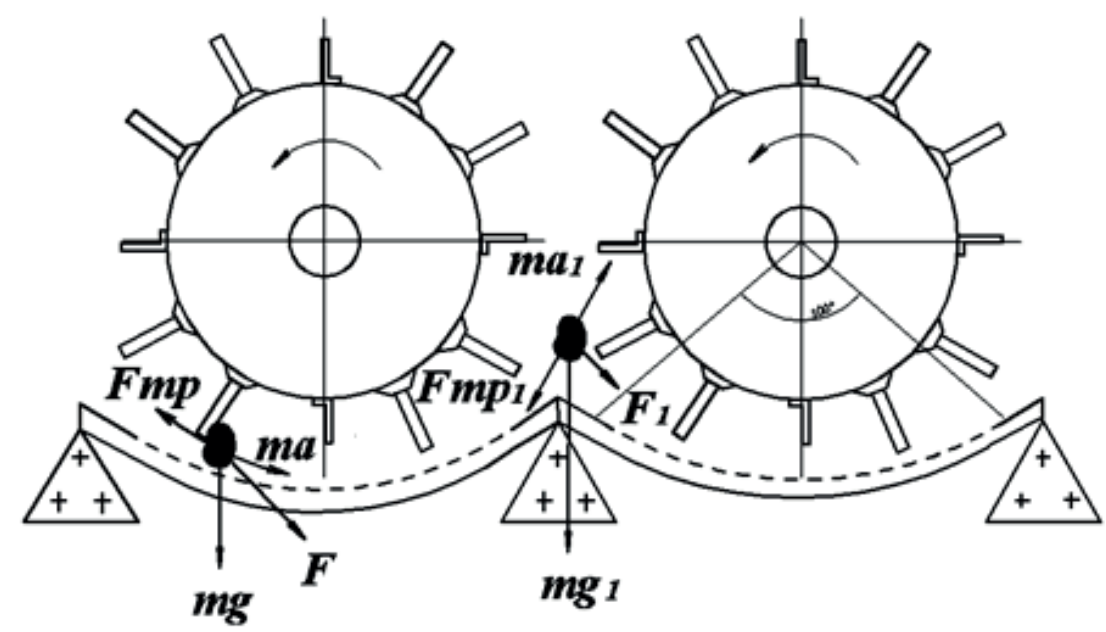

Pic. 2.2 Diagram of forces acting on raw cotton fly during cleaning from fine weed impurities.

We determine the value of the force acting on the raw cotton fly on the side of the pile drum by the following formula:

$$
\begin{aligned}
& F_{1}=m a-F_{i s h}=m a-\mu m g=m(a-\mu g)=m\left(v^{2} / R-\mu g\right)= \\
& =6 \cdot 10^{-2}(81 / 0,20-0,25 \cdot 9,8)=2,4 H
\end{aligned}
$$

here:

${ }^{\mu}$-coefficient of friction of raw cotton against steel surface;

$m$-mass of raw cotton fly;

$g$-acceleration of gravity;

$a$-faster fly of raw cotton.

After the first pile drum of the raw cotton fly-off comes to the second pile drum, which performs unidirectional movement. In case of counter movement of the second drum of the raw cotton fly, the impact receives the following force effects: $m g$ - gravity, $F_{1}=F$ - force acting on the side of the second pile drum, equal in magnitude to the force of action of the first drum [6;- p.233].

After the first pile drum of the raw cotton fly-off comes to the second pile drum, which performs unidirectional movement. In case of counter movement of the second drum of the raw cotton fly, the impact receives the following force effects: $m g=m g_{1}$ - gravity, $F=F_{1}$ - force acting on the side of the second pile drum, equal in magnitude to the force of action of the first drum.

It is known that in a rotating drum the speed distribution is different (Figure 3). According to this distribution, after flying out of the first drum at the point of contact with the second drum, the rotation speed of the pegged drum is equal $v=\sqrt{2 v}$.

1) on the $1 / 4$ part of the rotary drum: $v=\sqrt{2 v}$

2) on the $1 / 2$ part of the rotary drum: $v=v$

3) on the $3 / 4$ part of the rotary drum: $v=\sqrt{2 v}$

4)4) at full rotation of the rotating drum: $v=v$ 


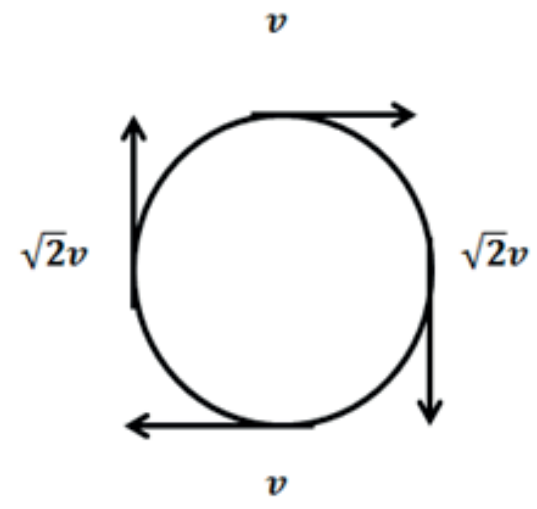

\section{Pic. 3 Distribution of rotation speeds in a rotating drum}

In the second drum, the acting forces on the fly will be equal.

$$
F_{1}=m a_{1}+m g_{1}
$$

Since the value $m g_{1}$ is small, the solution to this equation is:

$$
F_{1}=m a_{1}=m \cdot \frac{\vartheta_{1}}{R}=\frac{2 m \vartheta_{1}^{2}}{R}=\frac{6 \cdot 10^{-3} \cdot 2 \cdot 81}{0,2}=4,8 \mathrm{~N}
$$

Conclusions: The obtained results show that a total force of $7.2 \mathrm{~N}$ acts on a single fly of raw cotton when it is cleaned from fine weed impurities when moving from one pile drum to another. The repeated effect of this force leads to high mechanical damage to the seeds and the formation of short fibers that are removed from the machine along with weed impurities to waste [7; - p. 34-37].

Researches of the American scientific Patil.P.G., Anap G.R., Arude V.G. and Carlos B. Armijo, Kevin D. Baker, Sidney E. Hughs, Edward M. Barnes, вa confirm to Marvis N. in this direction our results, they prove that the number of mechanical impacts on cotton-raw considerably damage his natural quality indicators. Also, in order to achieve these goals, they conclude that in cotton cleaners the amount of pile drums is minimized by improving the assemblies and layout of machines [8 -c.158-165]. The calculations show that the existing technology of cleaning raw cotton from fine raw impurities is inefficient and to some extent negatively affects the natural quality indicators of processed raw cotton. According to the obtained results, a force equal to $7.2 \mathrm{~N}$. acts on the raw cotton fly when it is cleaned on fine soror cleaners when moving from one to the second drum.

In turn, this factor is the reason for the formation of fibrous waste, which makes it possible to conclude that it is necessary to modernize the horizontal layout of cleaning units with the transition to vertical technology for cleaning raw cotton.

\section{References:}

1. I.K. Sobirov Increasing fiber yield when processing high-moisture raw cotton Diss.... Doc. Techne. sciences. - Tashkent, 2017, - p. 25.

2. A.M. Aboukarima, H.A. Elsoury and M.Menyawi. Artificial Neural Network Model for the Prediction of the Cotton Crop Leaf Area. Agricultural Engineering Research Institute, Agricultural Research Centre, Dokki, Giza, Egypt.

3. Kh.S. Usmanov, A.M.Salimov, F.N. Sirozhiddinov Improving efficiency of raw cotton cleaning and analysis of factors influencing this process. Materials of the XXIV International Scientific Conference "EurasiaScience," 14.10.2019, - p.64-65.

4. Usmanov Kh.S.,Salimov A.M., Abbozov I.Z.,Doliyev A.T., Tangirov A.A Theoretical Analysis of the Effect of Spike Drums on the Natural Qualitative Indicators of Cotton at its Cleaning // International Journal of Advanced Research in Science,Engineering and Technology, India, Vol. 6, Issue 9 , September 2019, - pp.10742 - 10747. www.ijarset.com.

5. Usmanov Kh.S., Ismailov A.A., Makhmudov Yu. A. Calculation of power effects on the raw 
cotton fly with horizontal cleaning method technology//Materials of the XVI International scientific and practical Conference Cutting-edge science - 2020, April 30 - May 7, 2020: EDUCATION AND SCIENCE Ltd $-233 \mathrm{p}$.

6. H.S. Usmanov, M.A. Alimov, A.T Doliyev a ozichalara Drum buttermilk of a tolasig таъсир kuchina etuvch аниқлаш ва Nazariy Talili "Mashinashunoslikning долзарб muammolari ва an ularning echy" the Academician H.H. Usmonkh, zhayev a tavalludining 100 yilligig бағишланган the Republic of ilmy-amaliya of a konferentsiyasa мақолалар t,plam, Toshkent, yit 2019 20-21 November, 34-37 бетлар.

7. Patil.P.G., Anap G.R., Arude V.G. Design and development of cylinder type cotton pre-cleaner. Agricultural Mechanization in Asia, Africa and Latin America. 2014, ISSN: 00845841.

8. Carlos B. Armijo, Kevin D. Baker, Sidney E. Hughs, Edward M. Barnes, and Marvis N. Gillum Harvesting and Seed Cotton Cleaning of a Cotton Cultivar with a Fragile Seed Coat The Journal of Cotton Science 2009. №13:- pp.158-165). 


\title{
CALCULATION OF FORCE EFFECTS ON COTTON FLY DURING CLEANING ON VERTICAL CLEANER
}

\section{Sobirov Ilxom Khaxramanovich, Usmanov Xayrulla Saydullaevich, Khaitbaev Khursand \\ Tashkent Institute of Textile and Light Industry}

\begin{abstract}
The article contains materials on the analysis of the working units of the modernized raw cotton cleaner of the vertical principle of operation. Calculations of force effects on cotton fly were made at vertical method of cleaning from fine weed impurities.

Key words: cotton cleaning, cotton-cleaning unit, trash impurities, peel drum, mesh surface.

Introduction. Cotton cleaning plants and cotton-textile clusters currently operate serial eight-drum cleaners of SCH-02 grades, $1 \mathrm{KhK}$ and pile blocks of EN.178 grade as part of the UHK production line, developed in the late 80 s of the last century. Disadvantages in operation of existing horizontal technology of raw cotton cleaning from fine weeds (Fig.1,2 a) are considered in works [1-7] There is developed a vertical cotton cleanser from fine grain, which allows increasing the arc of the mesh surface by sequential movement of the pegged drums (Fig.1.2 b), which significantly increases the cleaning effect of the machine [8].

Research results. To study the nature of the movement of cotton fly in the section for cleaning cotton from small weeds, we will conduct a number of theoretical calculations. It is assumed that due to the small distances between the puncture drum and the opposite wall of the mesh surface, the velocity is constant and varies slightly.
\end{abstract}
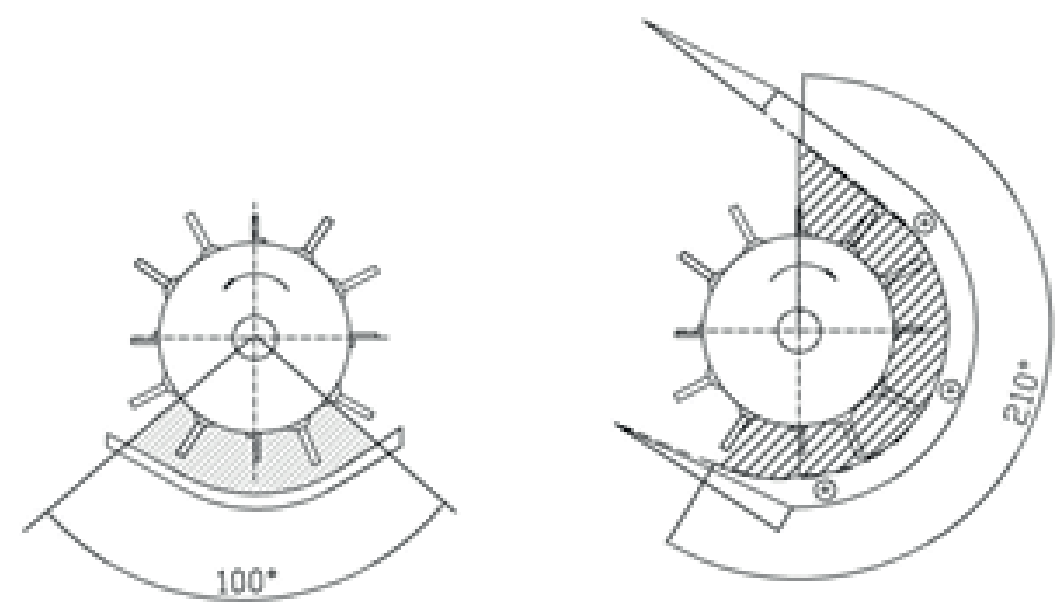

Fig.1 Diagram of the structure of the pile drum and mesh surface in the existing structures of the CCS cleaners (a) and proposed b).

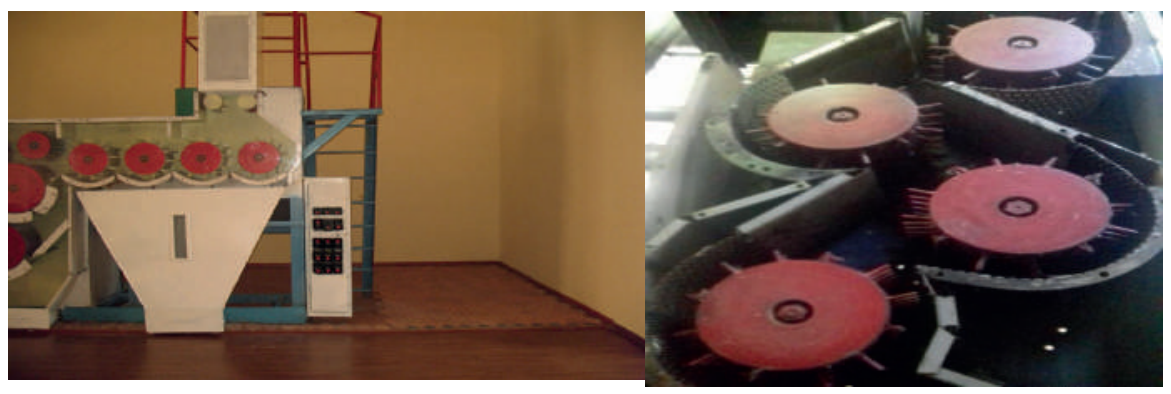

Fig. 2. Pegged drum and mesh surface structures in existing CCS cleaners (a) and proposed $b$ )

After the impact, the fly loses speed and enters the second drum under the influence of gravity, while the position of the fly in the flow changes, since when leaving the first pile drum on the second drum, it changes the side to be cleaned, to the reverse side (Figure 3). Upon entering the mesh surface 
of the second drum, which in the primary version is executed at an angle of $30^{\circ}$ to the horizontal axis of the first pile drum (Fig.4a), part of the cotton flow returns. This is due to the fact that after hitting the mesh surface, the cotton flow falls to the left of the center of the pile drum and the oncoming pile row, catching the incoming cotton, does not have time to completely drag the entire mass of cotton into the cleaning zone. To eliminate this negative phenomenon, by calculation, we selected the angle of inclination of the mesh surface relative to the horizontal axis of the first pile drum equal to $45^{\circ}$ (Fig. 4 b).

With these parameters, the angle of inclination of the mesh surface almost completely eliminated the amount of cotton that was returned when it was processed back. Further research to improve the shape and parameters of the mesh surface can completely eliminate this negative phenomenon.

In a vertical cotton cleaning unit with four rake drums, their speed from top to bottom starting in the first from $390 \mathrm{rpm}$ to $420 \mathrm{rpm}$. This eliminated bottomhole situations, ensured a uniform uninterrupted transportation of cotton along the puncture drums and significantly reduced the amount of cotton return to previous puncture drums (Fig. 5).

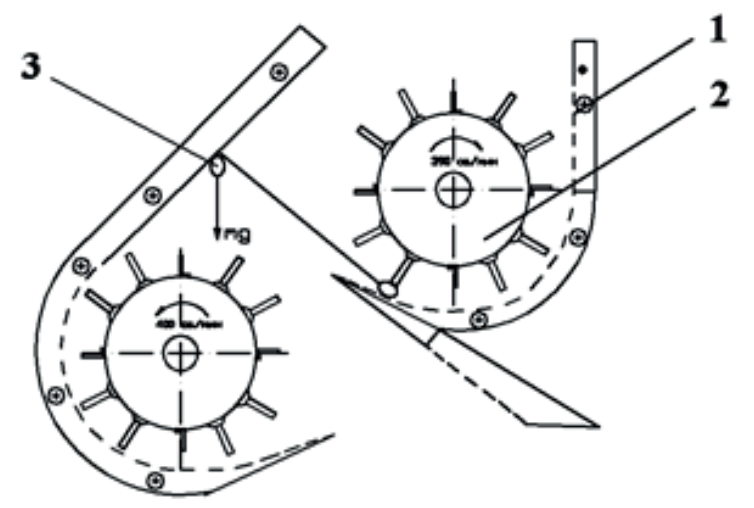

1.Mesh surface; 2. Bar drum; 3. Single fly in cotton flow

Fig. 3 Trajectory of cotton flywheel movement between flywheel drums of cotton cleaning unit during cleaning from fine dust

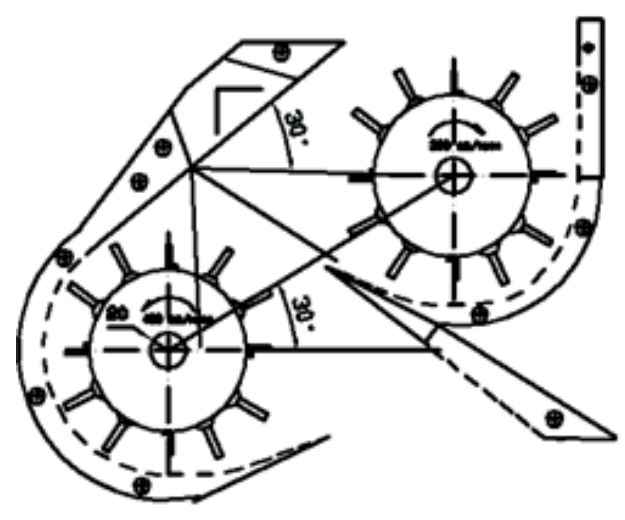

a) $\alpha_{1}=30^{0}$

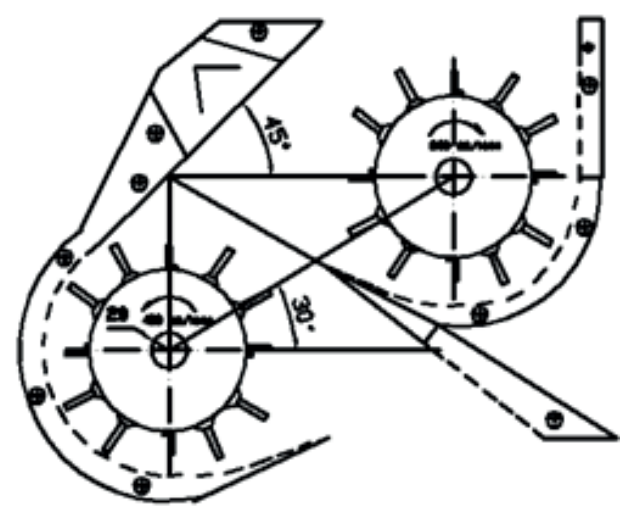

б) $\alpha_{2}=4^{0}$

Pic. 4 Diagram of change of inclination angle to horizontal axis of the first pile drum and area of cotton fall on the second pile drum

Another design feature of the vertical cotton cleaning unit is the girth angle of the mesh surface of the ramp. If this indicator in horizontal layout does not exceed the value of $g=100^{\circ}$, then in the modernized vertical cleaner, this indicator increased to $g=2100$, which is higher by 2.1 times the useful area of mesh surfaces of serial fine soror cleaners $1 \mathrm{KhK}$. If at horizontal technology of purification of cotton of small weed impurity the effectiveness ratio of "live" section doesn't exceed value $\eta=0.25 \div 0.30$, then in the offered option $\eta=0.58 \div 0.60$.

The next step in the calculations was to calculate the impact force of the cotton fly on the wall of the mesh surface after leaving the punch drums of a vertical cleaner consisting of four punch drums. 


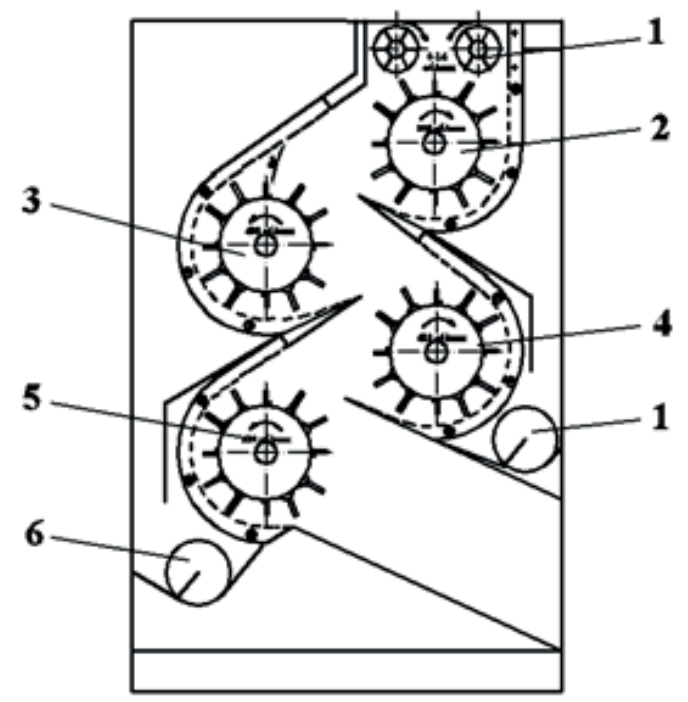

1. Feed rollers; 2. The first bar drum; 3. The second bar drum; 4. Third bar drum; 5. Fourth bar drum; 6. Weed screws

Pic. 5 Diagram of Four-Drum Fine Sludge Vertical Cleaner

After the cotton fly gets into the zone of cleaning from fine weeds, it is acted on it: centrifugal force $\mathrm{Fz}$, friction force Ftr and gravity P from the pile drum pegs (Fig. 6).

The rotation speed of the punch drums is different for each of the four punch drums starting at the top of the cleaner 390, 400, 410, $420 \mathrm{rpm}$, respectively.

$$
v_{1}=390 о б / \text { мин } ; v_{2}=400 о б / \text { мин } ; v_{3}=410 о б / \text { мин } ; v_{4}=420 о б / \text { мин. }
$$

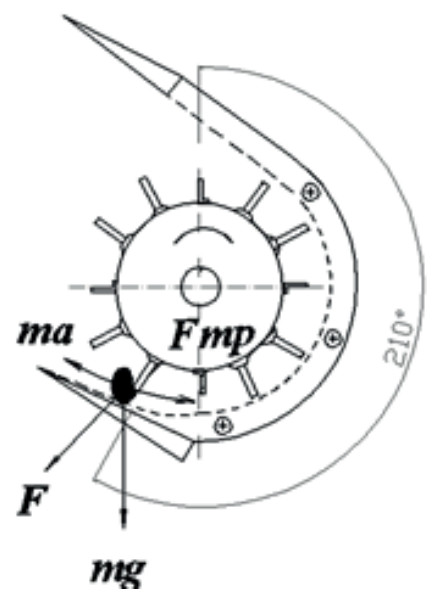

Fig.6 Diagram of active forces on cotton fly at vertical cotton cleaning diagram

The distance between the axes of the drums is $d=400 \mathrm{~mm}$, the radius of the drum with a mesh surface is $R=200 \mathrm{~mm}$, the length of the pegs is $l=50 \mathrm{~mm}$, the average mass of one cotton fly is taken to be $m=6 \mathrm{~g}$.

To determine the forces acting on the cotton fly, we calculate the linear speed of each pile drum according to the formula $v=2 \pi R v$.

$\mathrm{R}$-radius of pegged drum, $\mathrm{V}$ - rotation speed of pegged drum, $\mathrm{pi}=3.14$. Then it is determined value of forces acting on cotton fly during its cleaning from fine weed impurities at vertical technology of cleaning on each tear drum.

We perform calculations for the first bell drum:

$$
v_{1}=390 о б / \text { мин }=6,5 о б / с е к
$$




$$
\begin{gathered}
v_{1}=2 \pi R v_{1}=2 * 3,14 * 2,0 * 6,5=8,98 \text { м } / \text { сек } \\
F_{1}=m a-F_{p a \sigma}=m(a-\mu \mathrm{g})=m\left(\frac{v_{1}^{2}}{R}-\mu \mathrm{g}\right)=6 * 10^{-3}\left(\left(\frac{8,98^{2}}{0,20}\right)-0,25 * 9,8\right)=2,2 \mathrm{~N}
\end{gathered}
$$

Here $\mu=0.25$-coefficient of friction of cotton about a steel surface; $m$ - the mass of a short meeting of cotton, acceleration of gravity, and $g=9,8 \mathrm{M} / \mathrm{ce \kappa}$ - acceleration of a short meeting of cotton. According to the calculations carried out after the first pile drum, the cotton fly is affected by the force $F_{1}=2,2 \mathrm{~N}$ with which the fly hits the mesh wall of the second pile drum $v_{1}=6,5 \mathrm{M} /$ сек at a linear speed. When the cotton fly falls under the influence of its own weight, the second pile drum is affected by the following force from the side of this pile drum:

$$
\begin{gathered}
v_{2}=400 \text { об } / \text { мин }=6,67 \text { об } / \text { сек } \\
v_{2}=2 \pi R v_{2}=2 * 3,14 * 2,2 * 6,67=9,21 \text { м } / \text { сек } \\
F_{2}=m\left(\frac{v_{2}^{2}}{R}-\mu \mathrm{g}\right)=6 * 10^{-3}\left(\left(\frac{9,21^{2}}{0,20}\right)-0,25 * 9,8\right)=2,3 \mathrm{~N}
\end{gathered}
$$

When the cotton fly falls under the influence of its own weight, the third pile drum is affected by the following force from the side of this pile drum:

$$
\begin{gathered}
v_{3}=410 \text { об } / \text { мин }=6,83 \text { об } / \text { сек } \\
v_{3}=2 \pi R v_{3}=2 * 3,14 * 2,2 * 6,83=9,44 \text { м } / \text { сек } \\
F_{3}=m\left(\frac{v_{3}^{2}}{R}-\mu \mathrm{g}\right)=6 * 10^{-3}\left(\left(\frac{9,44^{2}}{0,20}\right)-0,25 * 9,8\right)=2,4 \mathrm{~N}
\end{gathered}
$$

When the cotton fly falls under the influence of its own weight, the fourth pile drum is affected by the following force from the side of this pile drum:

$$
\begin{gathered}
v_{4}=420 \text { об } / \text { мин }=7,0 \text { об } / \text { сек } \\
v_{4}=2 \pi R v_{4}=2 * 3,14 * 2,2 * 7,0=9,67 \mathrm{M} / \mathrm{ce \kappa} \\
F_{4}=m\left(\frac{v_{4}^{2}}{R}-\mu \mathrm{g}\right)=6 * 10^{-3}\left(\left(\frac{9,67}{0,20}\right)-0,25 * 9,8\right)=2,5 \mathrm{~N}
\end{gathered}
$$

Conclusions: The obtained results revealed that with the vertical technology of cleaning cotton from fine weeds, the amount of impact effects is much smaller than in the horizontal cleaning technology and practically does not affect the natural quality indicators of overexpended cotton.

Oprededeno, that at horizontal technology of purification of cotton of small weed impurity the effectiveness ratio of "live" section doesn't exceed value $\eta=0.25 \div 0.30$, at vertical technology of cleaning this rate is $\eta=0.58 \div 0.60$ that is the main reason for improvement of purification of cotton of small weed impurity.

In a complete set of vertical cleaner of cotton from small weed impurity in number of four the bar of drums operating forces on a short meeting of cotton and rotation frequency the bar of drums increase in the following sequence of $\mathrm{F} 1<\mathrm{F} 2<\mathrm{F} 3<\mathrm{F} 4$ and $v 1<v 2<v 3<v 4$ that is the reason of highly effective vertical technology of purification of cotton of small weed impurity.

When cleaning cotton from fine waste impurities according to the existing horizontal cleaning technology, the rotation speed of the lump drums is $9 \mathrm{~m} / \mathrm{s}$. 
With vertical cotton cleaning technology, it is possible to increase the speed of the pegged drums to $9.67 \mathrm{~m} / \mathrm{s}$. This is due to the fact that there are no counter impact effects of pegged drums present in horizontal cotton cleaning technology, which negatively affect the natural quality indicators of processed cotton.

Due to the absence of counter impact effects on the processed cotton, loads on electric engines decreased significantly, as a result of which, instead of the total power with a horizontal technology for cleaning cotton from fine weed impurities, $\mathrm{W}=11 \mathrm{~kW} *$ hour, with a vertical technology for cleaning from fine weed impurities amounted to $\mathrm{W}=6 \mathrm{~kW} *$ hour.

\section{References:}

1. I.K. Sobirov Increasing fiber yield when processing high-moisture raw cotton Diss.... Doc. Techne. sciences. - Tashkent, 2017, - p. 25.

2. Lugachev A.E. Study of the main elements of raw cotton cleaners in order to increase the quality indicators of the process: Diss... sciences.: - Kostroma, 1981. - page 31-32.

3. S.D. Boltabayev Preliminary cleaning of raw cotton from weed impurities: Diss... sciences: Tashkent, 1949, - p. 156.

4. E.F. Budin Research of sawdust sawdust working tools cotton cleaners machine collection medium fiber varieties Diss... sciences: - Tashkent, 1968, - c.146.

5. G.I. Miroshnichenko Basic design of primary cotton processing machines. M.: Engineering, 1972. - 143 b.],

6. V.A. Bogomolov Research and selection of the process of cleaning cotton machine harvested in the Republic of Azerbaijan,: Diss... sciences: - Kirovabad, 1974, - p. 171.

7. A.L.Sapon Research and development of technological progress of primary processing of raw cotton by machine collection of full-process production line: Diss... sciences: - Tashkent, 1978, c. 135 .

8. Kh.S. Usmanov and other Cotton Cleaning Unit Patent for Utility Model No. FAP 01397 of the Intellectual Property Agency of the Republic of Uzbekistan from 26.06.2019 


\section{MATERIALS \\ OF THE INTERNATIONAL SCIENTIFIC AND \\ PRACTICAL CONFERENCE}

\section{MODERN VIEWS AND RESEARCH - 2021}

JANUARY-FEBRUARY, 2021

Egham

2021

Independent Publishing Network Ltd 